\title{
CLONING, EXPRESSION AND PURIFICATION OF THE CYTOKINE FLT3-LIGAND FOR PROTEIN INTERACTION STUDIES
}

\author{
By \\ Lauren Alicia Agro \\ B.Sc. University of Guelph, 2009. \\ A thesis \\ Presented to Ryerson University \\ In partial fulfillment of the \\ requirements for the degree of \\ Master of Science \\ in the Program of \\ Molecular Science
}

Toronto, Ontario, Canada (2011)

(C) Lauren Agro (2011) 


\section{Author's Declaration}

I hereby declare that I am the sole author of this thesis or dissertation.

I authorize Ryerson University to lend this thesis or dissertation to other institutions or individuals for the purpose of scholarly research.

Lauren Agro

I further authorize Ryerson University to reproduce this thesis or dissertation by photocopying or by other means, in total or in part, at the request of other institutions or individuals for the purpose of scholarly research. 


\title{
CLONING, EXPRESSION AND PURIFICATION OF THE CYTOKINE FLT3-LIGAND FOR PROTEIN INTERACTION STUDIES
}

\author{
Lauren Alicia Agro \\ M.Sc. in Molecular Science, Ryerson University, 2011
}

\begin{abstract}
The FLT3-FLT3L receptor complex is responsible for the proliferation and differentiation of hematopoietic progenitor and stem cells, and is involved in several hematological malignancies. A truncated, soluble form of FLT3L was amplified from the fulllength sequence by PCR and cloned into a genomic integration and expression vector for Kluyveromyces lactis. Expression and secretion of the 161 amino acid FLT3L was analyzed by SDS-PAGE and Western blot and showed smeared bands around 50kDa consistent with a high level of varying glycosylation as expected. A yield of $100 \mathrm{ug} / \mathrm{mL}$ of culture was obtained. Purification was performed by Ni-affinity chromatography and the protein was confirmed to be in the elution fraction via mass spectrometry analysis. Purified FLT3L was able to activate RAW264.7 cells after $24 \mathrm{hr}$ incubation period causing large vacuoles and a dendritic appearance. FLT3L will be utilized for LARC protein interaction studies to search for interactors that might serve as therapeutic agents in human body fluids and cell culture models of myeloid leukemia.
\end{abstract}




\section{AKNOWLEDGEMENTS}

I want to thank my supervisor, Dr. John Marshall, for his continued support and belief in me throughout my time at Ryerson. I would also like to thank all the other members of the Marshall lab, especially Angelica Florentinus, Thanusi Thavarajah, and Jeffery Howard for all their help with this project. Dr. Ming Maio from Sick Kids, Toronto, was also a huge help throughout my project and was able to provide valuable advice. Additionally, I would like to thank my committee members Dr. Botelho and Dr. Fillingham for their support, insight, and guidance throughout my years at Ryerson. I am also deeply grateful to Dr. Rickey Yada, and to Brian Bryksa for taking the time to teach me biochemistry techniques as an undergraduate student at the University of Guelph, and for fostering my love of biochemistry.

Outside of the lab, my friends and family were always there to help. I want to thank Jessica Smith, Katie Alyman, and Marc Druart for sticking with me and supporting me when I was going through some very difficult times. Thank you to my parents, Sam and Linda Agro, as well as my aunt, Mary Ono, for unconditionally always being there for me and supporting me in everything I do. Thank you aunt Mary for always listening to me, helping me whenever possible, and for always giving me a different perspective on my problems. I surely would not have made it this far in life without you. Thank you dad for understanding me, and being there for me when times were rough and I needed a shoulder to cry on. Thank you mom for pushing me to be the best I could be and making me stronger. Growing up, you told me to take science in school and to always continue learning. I hope I've made you proud. Lastly, I want to thank my nonna, Salvina Schillaci-Ventura, for instilling in me a sense of respect, confidence, and dedication. I hope that you are looking down on me and are proud of what I have accomplished and the person I have become.

Thank you. 


\section{$\underline{\text { Dedication }}$}

This thesis is dedicated to my sisters, Julia and Jessica Agro. We have been through many hard times together, but we are stronger, smarter, and braver because of it. I am thankful everyday that I still have both of you in my life. You are truly my inspiration for everything I do, thank you for being my best friends and greatest supporters. 


\section{TABLE OF CONTENTS}

AUTHOR'S DECLARATION.............................................................II

ABSTRACT

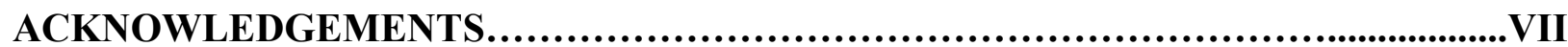

DEDICATION

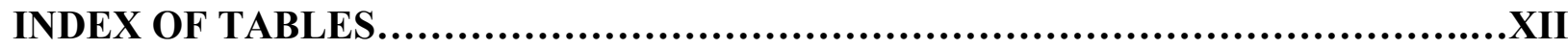

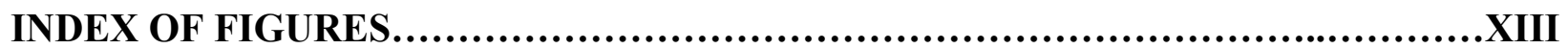

INDEX OF APPENDICES...............................................................XV

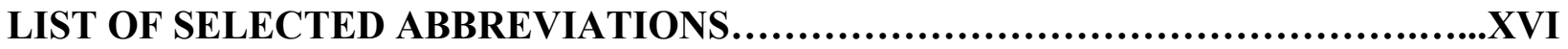

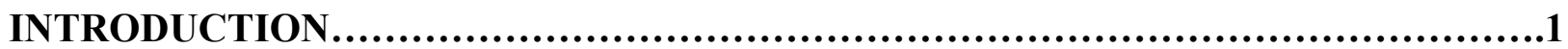

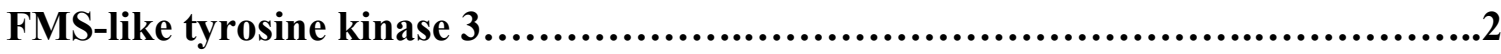

FMS-like tyrosine kinase 3 ligand................................................

Receptor-ligand activation and degradation...........................................6

FLT3 known associated pathways and components................................8

Biological significance of FLT3...............................................12

FLT3 mutations and effects...........................................................14

Clinical significance of FLT3 and use of Inhibitors...............................17

Previous attempts to express and purify FLT3L...............................18

Activity in other cell lines........................................................24

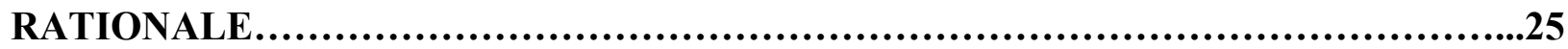

MATERIALS AND METHODS.......................................................27 
Reagents

Experimental Procedures..........................................................28

Cloning of FLT3L in E.coli..............................................28

PCR and primer design................................................... 28

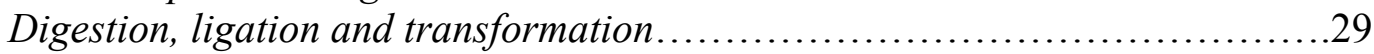

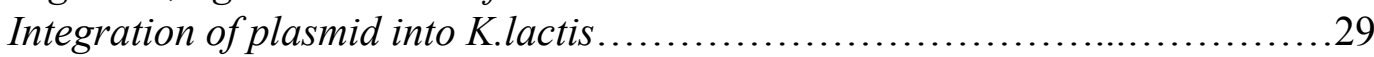

Western dot-blot....................................................... 30

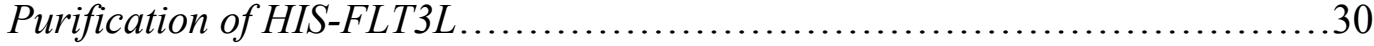

Cells

Supernatant

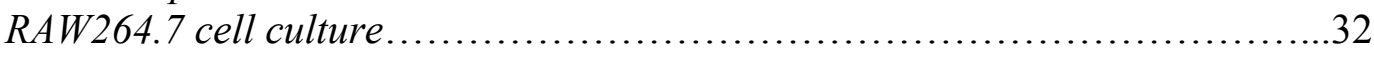

Confirmation of FLT3 Receptor in RAW264.7 cells.........................32

RAW264.7 activity assay .....................................................

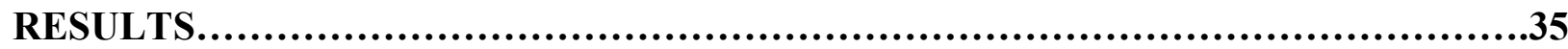

Cloning of HIS-FLT3LpKLAC2 and FLT3L-pKLAC2.........................35

Expression and Purification of HIS-FLT3L........................................39

HIS-FLT3L Activity Assays....................................................48

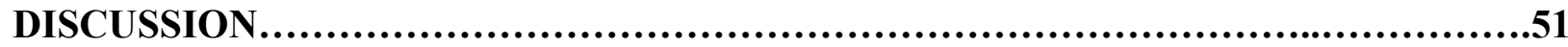

Purification of HIS-FLT3L......................................................51

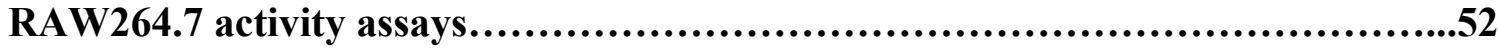

Future implications of results....................................................53

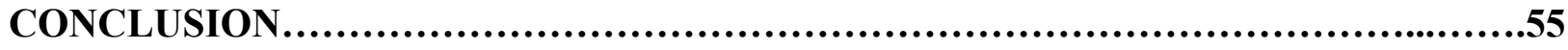

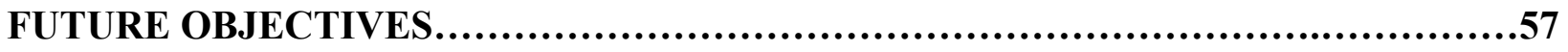

REFERENCES........................................................................59 


\section{INDEX OF TABLES}

Table 1: Summary of FLT3L expression papers....................................22

Table 2 : Summary of FLT3L expression papers (Full articles unavailable, foreign

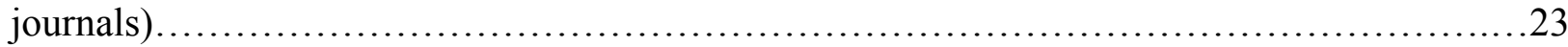

Table 3: Bradford assay on HIS-FLT3LpKLAC fractions after Ni-affinity

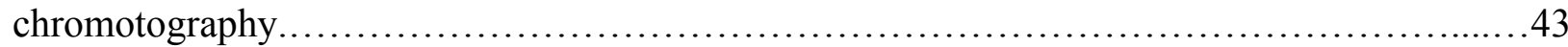

Table 4: First 15 hits from MS of 9\% tricine SDS PAGE cut gel band (E250, 75, $50 \mathrm{kDa}) \ldots \ldots . . .43$

Table 5: RAW264.7 Data from an IgG LARC experiment.................................... 75 


\section{INDEX OF FIGURES}

Figure 1: Crystal structure of the 344 amino acid catalytic domain of FLT3 from Protein Data Bank (Image 1RJB) ............................................................

Figure 2: BLAST of human (hFlt3L) and murine (mFlt3L) FLT3L........................4

Figure 3: Crystal structure of the 134 amino acid receptor binding domain of human FLT3L from Protein Data Bank (Image 1ETE) ....................................................

Figure 4: Life cycle of the FLT3 receptor...........................................

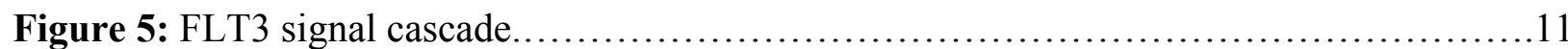

Figure 6: Purified pDC406 cut with BamHI and EcoRI on a 1\% agarose gel..................35

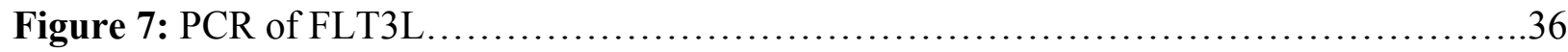

Figure 8: Restriction digests of positive ligations of FLT3L and pKLAC2 $\ldots \ldots \ldots \ldots \ldots \ldots \ldots$

Figure 9: HIS-FLT3LpKLAC2 and FLT3LpKLAC2 plasmid maps.......................37

Figure 10: 1\% agarose gel displaying strains of K.lactis with integrated HIS-FLT3LpKLAC2

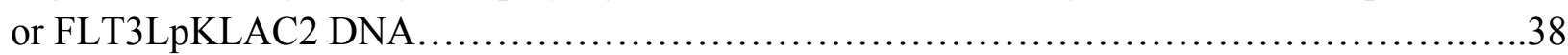

Figure 11: Western dot-blot of K.lactis crude supernatant................................

Figure 12: Coomassie stained $9 \%$ SDS-PAGE of HIS-FLT3LpKLAC2 and Control fractions

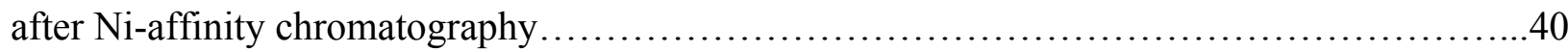

Figure 13: Western blot of Ni- affinity chromatography fractions of HIS-FLT3LpKLAC2 .....40

Figure 14: Coomassie stained $9 \%$ SDS-PAGE of HIS-FLT3LpKLAC2 and FLT3LpKLAC2

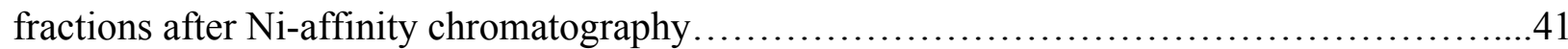

Figure 15:Western blot of HIS-FLT3LpKLAC2 and FLT3LpKLAC2 fractions after Ni-affinity chromatography .41

Figure 16: 9\% Coomassie stained SDS-PAGE of Control, FLT3LpKLAC2, and HISFLT3LpKLAC2 supernatant and all other HIS-FLT3LpKLAC2 fractions after Ni-affinity chromatography....

Figure 17: Western blot of Control, FLT3LpKLAC2, and HIS-FLT3LpKLAC2 supernatant and all other HIS-FLT3LpKLAC2 fractions after Ni-affinity chromatography.... .42

Figure 18: Full nucleotide and amino acid sequence of murine FLT3L.....................44 
Figure 19: Mass spectrometry TIC and Base Peaks, respectively for elution gel bands cut from

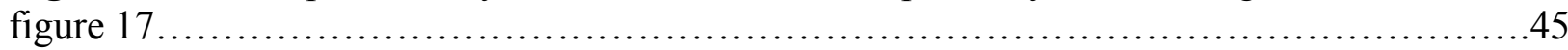

Figure 20: MS and MS/MS data respectively, from FLT3L found in elution gel bands cut from

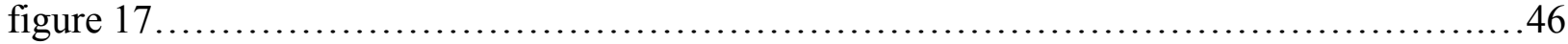

Figure 21: Mass spectrum of FLT3L originating from bands cut from figure $17 \ldots \ldots \ldots \ldots \ldots . .47$

Figure 22: Western blot of RAW264.7 cell lysate with anti-FLT3 mouse, rabbit IgG..........48

Figure 23: Images of RAW264.7 cells exposed to HIS-FLT3L or control yeast supernatant.....49

Figure 24: 9\% SDS-PAGE and (B) Western blot of the cytosol of a control strains of yeast, 3 strains of HIS-FLT3L yeast, and 3 strains of FLT3L yeast.

Figure 25: 9\% SDS-PAGE and (B) Western blot of the membranes of a control strains of yeast, 3 strains of HIS-FLT3L yeast, and 3 strains of FLT3L yeast.

Figure 26: 9\% Coomassie stained SDS-PAGE and western blot of HIS-FLT3L supernatant and all other fractions after Ni-affinity chromatography .70

Figure 27: Western blot of Ni-affinity chromatography fractions from FLT3L-HIS 1 alongside a

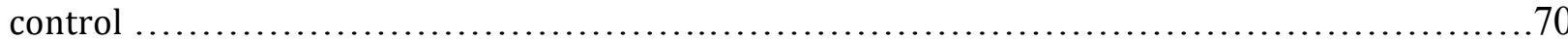

Figure 28: Western blot of HIS-FLT3LpKLAC2 fractions after Ni-affinity chromatography...71

Figure 29: Model of FLT3 murine receptor interactors predicted by STRING 9.0 based on experimental, database, textmining and homology information.............................73

Figure 30: Model of FLT3 human ligand interactors predicted by Cytoscape based on

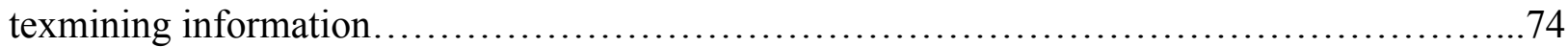

Figure 31: BSA calibration curve for spectrophotomeric protein assay ......................77

Figure 32: BSA calibration curve for spectrophotomeric protein assay .......................78 


\section{INDEX OF APPENDICES}

APPENDIX A - ADDITIONAL FLT3L SEQUENCE INFORMATION

APPENDIX B - PLACEMENT OF FORWARD AND REVERSE PRIMERS FOR FLT3L

AND HIS-FLT3

APPENDIX C - BLAST OF EXTRACELLULAR REGION OF FLT3L WITH POSITIVE

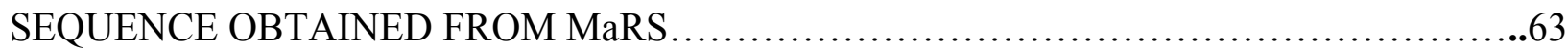

APPENDIX D - TRANSLATED CONFIRMED SEQUENCE OPEN READING FRAME OF

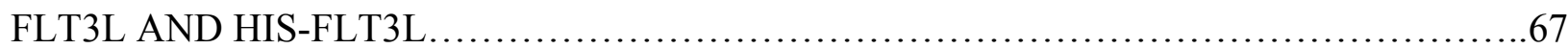

APPENDIX E - ADDITIONAL SDS-PAGE AND WESTERN BLOT IMAGES............69

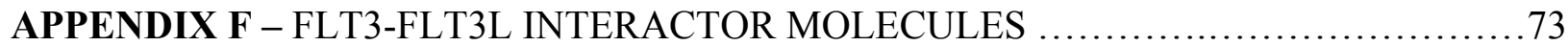

APPENDIX G - RAW264.7 DATA FROM AN IgG LARC EXPERIMENT................75

APPENDIX H - BSA CALIBRATION CURVES AND CALCULATIONS..................77 


\section{LIST OF SELECTED ABBREVIATIONS}

\begin{tabular}{|c|c|}
\hline AKT & Akt family of serine/threonine protein kinases \\
\hline ALL & Acute Lymphoblastic Leukemia \\
\hline AML & Acute Myeloid Leukemia \\
\hline Bax & BCL2-associated X protein \\
\hline BCL-2 & B-cell lymphoma 2 \\
\hline BLAST & Basic Local Alignment Search Tool \\
\hline BSA & Bovine Serum Albumin \\
\hline $\mathrm{C} / \mathrm{EBP} \alpha$ & CCAAT/enhancer-binding protein alpha \\
\hline CBL & (Casitas B-lineage Lymphoma) gene that encodes E3 ubiquitin-protein ligase \\
\hline CBLB & (Casitas B-lineage Lymphoma) gene that encodes E3 ubiquitin-protein ligase B \\
\hline CD34+ & Cluster of differentiation 34 \\
\hline CD46 & Cluster of differentiation 46 \\
\hline CD86 & Cluster of differentiation 86 \\
\hline Co-IP & Co-Immunoprecipitation \\
\hline CSF & Colony stimulating factor \\
\hline CSF1 & Colony stimulating factor 1 \\
\hline $\mathrm{DC}$ & Dendritic Cell \\
\hline E. Coli & Escherichia coli \\
\hline EPO & Erythropoietin \\
\hline ERK & Extracellular-signal-regulated Kinsase \\
\hline ESI & Electrospray Ionization \\
\hline FIZ1 & FLT3-interacting Zinc Finger \\
\hline FLT3 & FMS-like tyrosine kinase \\
\hline FLT3L & FMS-like tyrosine kinase ligand \\
\hline FMS & Macrophage Colony-stimulating Factor Receptor \\
\hline G-CSF & Granulocyte Colony-stimulating Factor \\
\hline GM-CSF & Granulocyte-macrophage Colony-stimulating Factor \\
\hline Grb & Growth Factor Receptor-bound Protein \\
\hline GTPase & Enzyme that hydrolyzes guanosine triphosphate \\
\hline HIS & Histadine protein tag \\
\hline HMW & High Molecular Weight \\
\hline Hoxa9 & Homeobox A9 \\
\hline HPLC & High-performance liquid chromatography \\
\hline IL-3 & Interleukin 3 \\
\hline IL-4 & Interleukin 4 \\
\hline IL-6 & Interleukin 6 \\
\hline IL-7 & Interleukin 7 \\
\hline IL-10 & Interleukin 10 \\
\hline IL-16 & Interleukin 16 \\
\hline IL-18 & Interleukin 18 \\
\hline ITD & Internal Tandem Duplication \\
\hline K. Lactis & Kluyveromyces lactis \\
\hline $\mathrm{kb}$ & Kilobase \\
\hline $\mathrm{kDa}$ & Kilodalton \\
\hline KIT & Steel Factor Receptor \\
\hline LARC & Live Cell Affinity Chromatography \\
\hline LB & Lysogeny Broth \\
\hline $\mathrm{LC}$ & Liquid chromatography \\
\hline
\end{tabular}




$\begin{array}{ll}\text { LMW } & \text { Low Molecular Weight } \\ \text { MAPK } & \text { Mitogen-activated Protein Kinase } \\ \text { MCL-1 } & \text { Myeloid cell leukemia-1 } \\ \text { MDS } & \text { Myelodysplasia } \\ \text { Meis1 } & \text { Homeobox protein Meis1 } \\ \text { MEK } & \text { Protein-serine/threonine and tyrosine kinase } \\ \text { MLL } & \text { Mixed Lineage Leukemia } \\ \text { MS } & \text { Mass Spectrometry } \\ \text { MS/MS } & \text { Tandem mass spectrometry } \\ \text { Ni-NTA } & \text { Nickel-nitrilotriacetic acid } \\ \text { NK } & \text { Natural Killer Cell } \\ \text { NPM1 } & \text { Nucleophosmin 1 } \\ \text { NUP98-HOX } & \text { Oncogenes isolated in myeloid leukemias } \\ \text { p85 } & \text { Regulatory subunit of class one PI3Ks } \\ \text { P. Pastoris } & \text { Pichia pastoris } \\ \text { PAGE } & \text { Polyacrylamide Gel Electrophoresis } \\ \text { PAX5 } & \text { Paired box protein } \\ \text { PBS } & \text { Phosphate Buffered Saline } \\ \text { PDGFR } & \text { Platelet-derived Growth Factor } \\ \text { pI } & \text { Isoelectric Point } \\ \text { PI3K } & \text { Phosphatidylinositol-3-kinase } \\ \text { Pim-1 } & \text { Proto-oncogene Serine/threonine-protien Kinase } \\ \text { PU.1 } & \text { Transcription factor that binds to purine rich sequences of promoters. } \\ \text { PVDF } & \text { Polyvinylidene fluoride } \\ \text { RAF-1 } & \text { V-raf-1 murine leukemia viral oncogene homolog } \\ \text { RAS } & \text { (Rat sarcoma)single-subunit small GTPase } \\ \text { RAW264.7 } & \text { Murine macrophage-like cell line } \\ \text { RTK } & \text { Receptor Tyrosine Kinase } \\ \text { SCF } & \text { Stem Cell Factor } \\ \text { SCH } & \text { Src Homology 2 domain Containing } \\ \text { SDS } & \text { Sodium Dodecylsulfate } \\ \text { SH2 } & \text { SRC Homology 2 } \\ \text { SHIP } & \text { SH2-domain-containing inositol phosphatase } \\ \text { SHP2 } & \text { SH2 domain-containing tyrosine phosphatases } \\ \text { SRC } & \text { Proto-oncogenic tyrosine kinase } \\ \text { STAT } & \text { Signal Transducer and Activator of Transcription } \\ \text { TACE } & \text { TNF- } \alpha \text { converting enzyme } \\ \text { TBST } & \text { 1x PBS with 0.1\% Tween } \\ \text { TKD } & \text { Tyrosine Kinase Domain } \\ \text { Trx } & \text { Thioredoxin } \\ \text { VEGFR1 } & \text { Vascular endothelial growth factor receptor 1 } \\ \text { VEGFR } & \text { Vascular Endothelial Growth Factor Receptor } \\ \text { WT } & \text { Wildtype } \\ \text { YCB } & \text { Yeast Carbon Base } \\ & \end{array}$


xviii 


\section{INTRODUCTION}

Cell signalling is fundamental to life and cellular function. Cells receive a constant flow of information from membrane receptor proteins regarding the extracellular environment and as a result, the intracellular environment is altered accordingly. These signal transductions within the cell are highly sensitive and specific. Receptors have a high affinity for their specific ligands, and when a ligand-receptor complex is formed, a very specific cell response occurs via intracellular enzyme cascades. In animals, some membrane receptors regulate cell differentiation, growth, proliferation and death. When these receptors become mutated, they are often able to initiate a cellular signal cascade without the attachment of their complementary ligand. One frequent outcome of this is uncontrolled cellular division and tumor growth, ultimately leading to cancer. In order to work towards possible cures, it is important to understand the cause of these mutations, where they occur, and what happens inside of the cell when these signal cascades are activated.

One popular method of determining intracellular protein-protein interactions is to do coimmunoprecipitation (Co-IP) experiments (Sambrook \& Russell, 2001). Protein-protein associations are often preserved when cells are lysed under non-dentauring conditions, so proteins which associate with each other may be able to precipitate together (Sambrook \& Russell, 2001). In Co-IP, an antibody against the target protein is selected and 'pulls' that protein out of a solution of cell lysates (Sambrook \& Russell, 2001). If the target protein is part of a larger complex of proteins and is bound to its other interactor proteins, theoretically, those proteins will elute together along with the target protein. (Sambrook \& Russell, 2001). Elutions are fractionated by sodium dodecylsulfate polyacrylamide gel electrophoresis (SDS-PAGE) and detected by Western blot using an antibody towards proteins of interest (Sambrook \& Russell, 2001).

However, it is often difficult to isolate assembled receptor complexes from membranebound receptors since complete protein complexes may only assemble in live cells due to various factors including, but not limited to, the inclusion of the membrane and cytoskeleton-associated binding partners that would not normally reform in cell lystaes (Jankowski et al, 2008). Therefore, a method needs to be developed so that whole receptor complexes can be extracted 
from live cells. One such method is called live cell affinity chromatography (LARC), which uses a ligand attached to a microbead in order to activate and capture the full ligand-receptor complex from live cells (Jankowski et al, 2008). This method is able to capture fully assembled receptor complexes in their native state and is more sensitive and efficient than Co-IP (Jankowski et al, 2008). However, LARC requires large amounts of the ligand protein in order to do multiple trials of extraction experiments. Therefore, it is worthwhile to develop a protocol to obtain large amounts of the desired ligand. Here we develop a protocol to clone, express, and purify a soluble form of FLT3L for the purpose of LARC.

\section{FMS-like tyrosine kinase 3}

The FMS-like tyrosine kinase receptor (FLT3), also known as stem cell kinase-1 and fetal liver kinase-2, was first cloned in mouse fetal liver and placenta cells (Matthews et al, 1991; Rosnet et al, 1991). Later the human FLT3 gene (found on chromosome 13q12) was cloned with 86\% amino acid sequence homology with murine FLT3 (Rosnet et al, 1993b; Small et al, 1994). The human FLT3 gene encodes a 993 amino acid protein belonging to the receptor tyrosine kinase 3 (RTK3) family (Agnes et al, 1994). The FLT3 membrane bound receptor includes the following features; five immunoglobulin-like extracellular domains, a single transmembrane domain, a juxtamembrane domain, two intracellular tyrosine kinase domains linked by a kinase insert and 24 exons (Figure 1) (Abu-Duhier et al, 2001; Agnes et al, 1994). More recently, it was found that a zinc finger called Fiz1 binds to the catalytic domain of FLT3 (Wolf \& Rohrschneider, 1999).

Like all RTK3 members, FLT3 plays a role in proliferation, differentiation and apoptosis of haematopoietic cells (Rosnet et al, 1993c). Additional RTK3 members include macrophage colony-stimulating factor receptor (FMS), steel factor receptor (KIT) and receptors for plateletderived growth factors (PDGFR) A and B (Agnes et al, 1994). Two forms of human FLT3 exist including a $158-160 \mathrm{kDa}$ membrane bound protein glycosylated at external N-linked glycosylation sites, and a 130-143kDa protein that lacks membrane binding (Lyman et al, 1993a; Carow et al, 1996). Normal human cells express FLT3 in early CD34+ myeloid and lymphoid progenitors while avoiding erythroid cells, megakaryocytes or mast cells (Rosnet et al, 1996; 
Gabbianelli et al, 1995; Ratajczak et al, 1996; Hiertson et al, 1996). The developmental stages at which hematopoietic progenitors express FLT3 are unknown (Karsunky et al, 2003).

FLT3 is very important in the development of leukemia, as its mutations are involved in 45\% of acute myeloid leukemia cases (AML), 15\% myelodysplastic syndrome cases (MDS), and 5\% of acute lymphoblastic leukemia (ALL) cases (Carow et al,1996; Rosnet 1996). AML cells begin as multipotent colony-forming or myeloid-committed colony forming cells while B-cell ALL originates from immature progenitor B cells (Sabbath et al, 1985; Nadler et al, 1984). The chronic leukemias rarely express FLT3 due to the involvement of more mature lymphoctyes and cells that retain differentiation, resulting in the loss of FLT3 expression (Rubartelli et al, 1983; Martin et al, 1980). Recently, it has been found that ALL patients with translocations in the mixed lineage leukemia (MLL) gene, overexpressed wildtype FLT3 which may indicate that certain genetic interruptions influence FLT3 expression (Armstrong et al, 2002).

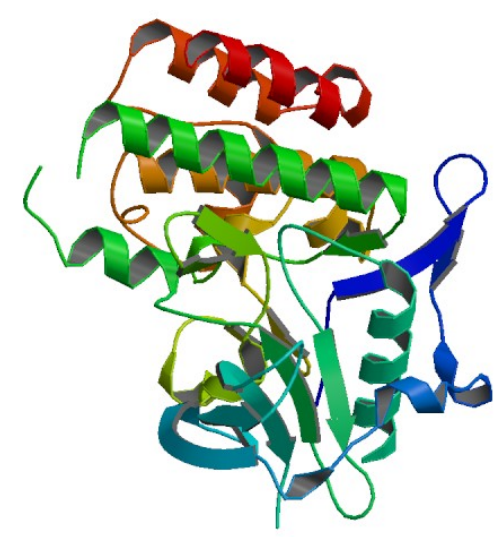

Figure 1. Crystal stucture of the 344 amino acid catalytic domain of FLT3 from Protein Data Bank (Image 1RJB) (Griffith et al, 2004).

\section{FMS-like tyrosine kinase ligand}

The mouse FLT3L gene was cloned first and the resulting cDNA was subsequently used to clone the human FLT3L gene (Lyman et al, 1993b; Hannum et al, 1994; Lyman et al, 1994a). The FLT3L gene encodes 232 and 235 amino acids in the mouse and human respectively and results in a 73\% homology at the amino acid level (Figure 2) (Stephen et al, 1997). The human FLT3L extracellular region is $73 \%$ similar in mouse while the cytoplasmic domain is only $52 \%$ 
similar (Lyman et al, 1998). The FLT3L is a type 1 transmembrane protein containing a 26 residue amino-terminal signalling peptide, four extracellular helical domains consisting of 156 residues, spacer and tether regions, a 23 residue transmembrane domain and a 30 residue cytoplasmic domain (Figure 3) (Lyman et al, 1998; Lyman et al, 1995a; Graddis et al, 1998). Lyman et. al (1993) predicated the molecular weight to be 23.164kDa after cleavage of the signal sequence with an estimated pI of 8.17. Both the KIT ligand and FMS ligand share intron/exon boundaries, sizes, and structures with FLT3 indicating ancestral relatedness (Lyman et al, 1998). The spacer and tether regions of the ligand link the active extracellular component to the transmembrane domain and anchors it to the cell. The cytoplasmic domain is reported to be uninvolved in stimulation of FLT3 and the function of this region is unknown (Lyman et al, 1998).

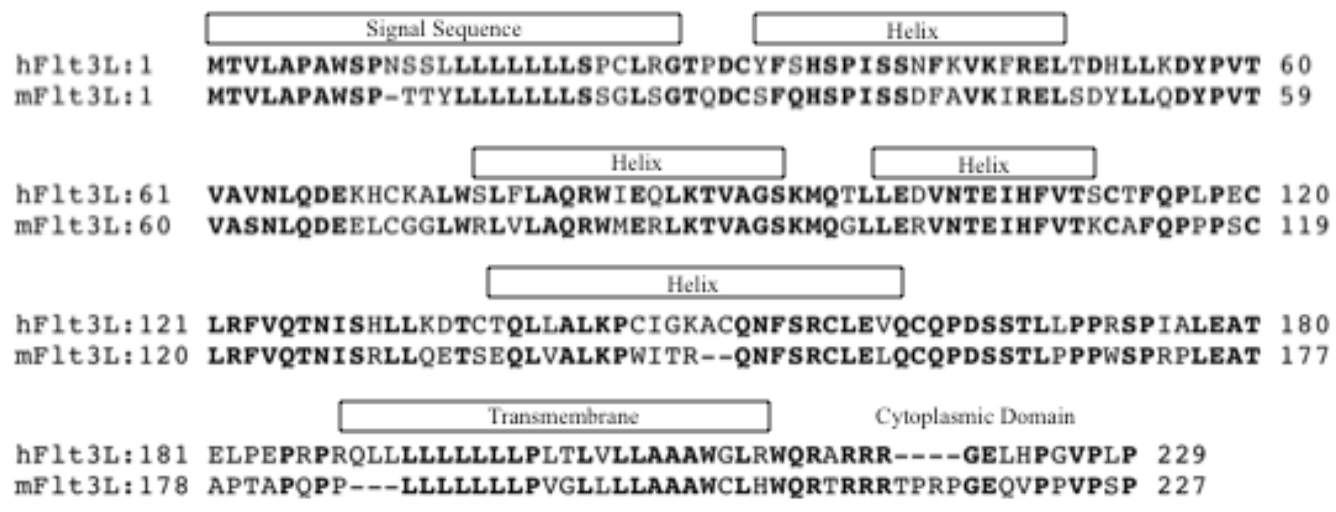

Figure 2. BLAST of human (hFlt3L) and murine (mFlt3L) FLT3L. Score $=296$ bits (759), Expect $=2 \mathrm{e}^{-85}$, Identities $=163 / 233(69 \%)$, Positives $=180 / 233(77 \%)$, Gaps $=10 / 233(4 \%)$. Adapted from Lyman et. al (1993b). 


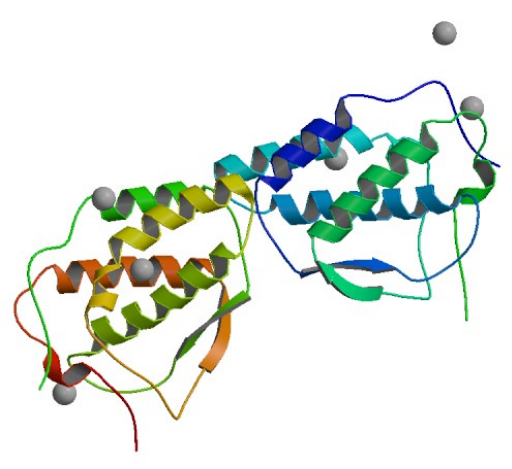

Figure 3. Crystal structure of the 134 amino acid receptor binding domain of human FLT3L from Protein Data Bank (Image 1ETE) (Savvides et al, 2000).

Like FLT3, there are a number of isoforms of FLT3L. The main human isoform is a full length transmembrane protein that is cleaved by TNF- $\alpha$ converting enzyme (TACE) in the spacer and tether region to produce a soluble isoform that is released into circulation (Hannum et al, 1994; Lyman et al, 1994b; Graddis et al, 1998; Horiuchi et al, 2009). Soluble FLT3L does not contain a carboxyl end and consists mainly of the extracellular portion of the protein. This soluble, noncovalently linked dimer contains 6 cysteine residues that form disulfide bonds (Lyman et al, 1998; Graddis et al, 1998). A rare soluble human FLT3L isoform has an alternatively spliced exon 6 resulting in an early stop codon (Lyman et al, 1998). In mice, the most abundant form of FLT3L is the membrane bound 220 amino acid protein that results from a failure to splice out an intron which creates a frame shift mutation encoding hydrophobic amino acids keeping the ligand at the cell surface (Lyman et al, 1998). Because this mutation causes an absence of the tether, spacer, and other regions that attach the ligand to the membrane, proteolytic cleavage does not occur (Lyman et al, 1995c). Another isoform of mouse FLT3L has an altered exon 6 splice much like the human equivalent (Lyman et al, 1998). Isoform relevance and expression preference in various tissues is currently unknown (Lyman et al, 1998). All human and murine FLT3L variants are biologically active but the relative activity is undetermined (Lyman et al, 1998). FLT3L does not show species specificity, which is contrary to other RTK ligands (Lyman et al, 1994a). 
Expression of FLT3L occurs in most tissues including; haematopoietic organs, prostate, ovary, kidney, lung, colon, small intestine, testis, heart, and placenta. Peripheral-blood mononuclear cells are found to have the highest FLT3L expression levels, with the brain showing little expression (Brasel et al, 1995; Meierhoff et al, 1995). Due to the extensive expression of FLT3L in comparison to low levels of FLT3 expression, FLT3 is considered the limiting factor in receptor-ligand activation (Lyman et al, 1995b). Serum levels of FLT3L are low in adults but seem to be inducible as evidenced by patients who have low white blood cell counts secondary to haematopoietic disease or chemotherapy who show increased serum concentrations of FLT3L in an attempt to encourage heamatopoiesis (Lyman et al, 1995b). This has been exploited in murine models to promote mobilization of haematopoietic stem cells with some success and in human trials to treat prostate cancer (Ashihara, 1998). More recently, Zhang et al. (2009) studied the effect of interleukin-3 (IL-3) and FLT3L over-expression in human cord blood CD34+ cells on rescuing lethally irradiated mice by transplantation. Isolated CD34+ cells were infected with a recombinant retrovirus expressing FLT3L, IL-3 or FLT3L/IL3 genes (Zhang et al, 2009). Results showed more human cells could be found in the bone marrow, spleen and peripheral blood of mice transplanted with the cells expressing FLT3L/IL-3 (Zhang et al, 2009). These mice also showed a greater recovery of peripheral blood counts and a much higher survival rate (Zhang et al, 2009). It is reasonable to believe that the further study of recombinant FLT3L as a treatment for various cancers would be valuable.

\section{Receptor-Ligand activation and degradation}

FMS-like tyrosine kinase 3 exists in an inactive monomer state in the plasma membrane (Gonfloni et al, 2000). Inactive monomers have a structural conformation that results in steric inhibition of dimerization by having the juxtamembrane domain cover the phosphoryl acceptor sites in the tyrosine kinase domain (TKD) (Gonfloni et al, 2000). This type of inhibition is consistent with other members of the RTK family (Gonfloni et al, 2000). After FLT3L stimulation, FLT3 undergoes a conformational change that exposes the phosphoryl acceptor sites to form a homodimer with another ligand bound FLT3 (Turner et al, 1996). The dimerization causes an increase in stability of the receptor complex and enhances receptor activation (Weiss \& Schlessinger, 1998). Once FLT3 has bound, phosphorylation of the TKD occurs within 5-15 
minutes. After 5-15 minutes of stimulation, the receptor complex is engulfed by the cell and degradation products appear after approximately 20 minutes (Figure 4) (Weiss \& Schlessinger, 1998). This rapid turnover of FLT3 is also consistent with other RTK3 receptors like KIT (Yee et al, 1993). The regulation of FLT3 production and degradation is most likely the result of complex feedback loops that are yet to be fully described. Low serum FLT3L concentrations and the close location of cells that highly express FLT3L to early progenitor haematopoietic cells containing FLT3, indicates receptor activation may be controlled via paracrine methods (Brasel et al, 1995). Autocrine feedback loops may also be involved, supported by the co-expression of FLT3L and FLT3 in the same cell allowing the cell to regulate its own level of FLT3 activation (Brasel et al, 1995). This autocrine regulation is also consistent with other growth factors like granulocyte-macrophage colony-stimulating factor (GM-CSF) and its associated receptor (Rogers et al, 1994). 


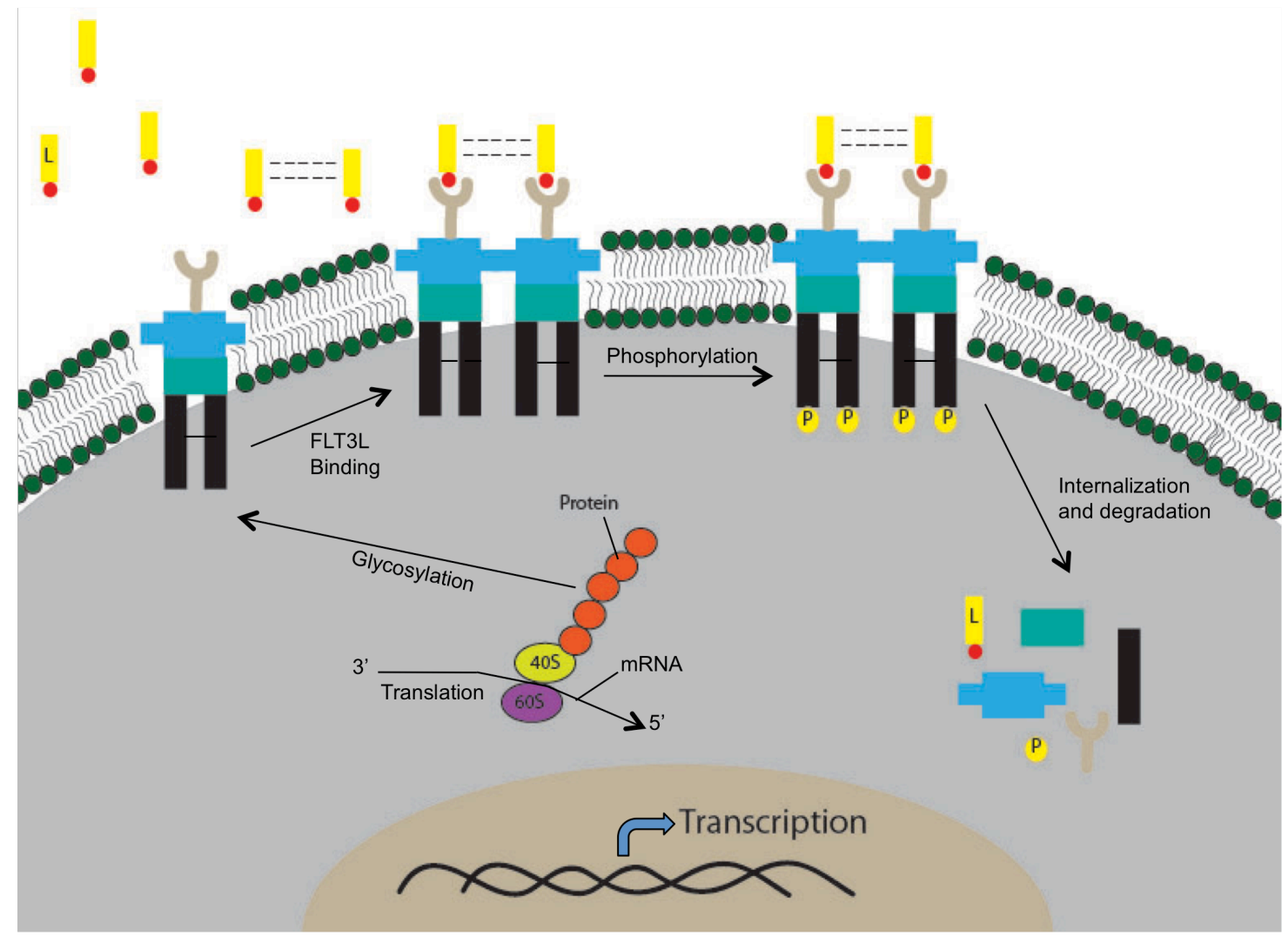

Figure 4. Life cycle of the FLT3 receptor. Transcription of the FLT3 gene results in mRNA, which is translated to FLT3 protein. Cytoplasmic FLT3 undergoes glycosylation, which promotes localization of the receptor to the membrane. When a FLT3L (L) dimer binds the monomeric receptor, it initiates receptor dimerization. Receptor dimerization promotes phosphorylation $(\mathrm{P})$ of the tyrosine-kinase domains, which activates the receptor and downstream effectors. The dimerized receptors are quickly internalized and degraded after about 15-20 minutes. Image adapted from Stirewalt et al, 2003.

\section{FLT3 known associated pathways and components}

Initially, the RTK-RAS pathway was studied using chimeric receptor complexes containing the extracellular ligand-binding domains of human FMS attached to the intracellular catalytic domains of mouse FLT3 (Dosil et al, 1993; Rottapel et al, 1994). Activation of this receptor complex with colony stimulating factor-1 (CSF1) transformed mouse cell lines resulted in cell proliferation without the aid of additional growth factors (Dosil et al, 1993; Rottapel et al, 1994). It was found that the FMS-FLT3 complex was directly associated with the Src-homology 
2 (SH2) domain of the p85 subunit of phosphatidylinositol-3-kinase (PI3K) and with growth factor receptor-bound protein 2 (Grb2) (Dosil et al, 1993; Rottapel et al, 1994). It was also found that there was an association with phospholipase $\mathrm{C}-\gamma 1, \mathrm{SH} 2$-containing sequence proteins and GTPase-activating protein (Dosil et al, 1993; Rottapel et al, 1994). This same FLT3 complex is also associated with SH2-domain-containing inositol phosphatase (SHIP) (Marchetto et al, 1999).

After FLT3L was cloned, direct FLT3-FLT3L studies were conducted with similar results to the pathways associated with the FMS-FLT3 complex (Lyman et al, 1993b; Lyman et al, 1994b). Src homology 2 domain containing (SHC) proteins were phosphorylated and interacted or formed complexes with other proteins like Growth Factor Receptor-bound Protein (GRB), GRB2-associated binder 2, and SHIP (Figure 5) (Marchetto et al, 1999; Zhang et al, 1999a; Lavagna-Sevenier et al, 1998; Zhang et al, 2000a). The adaptor protein complexes most likely mediate downstream molecules in the RAS-RAF-MEK- extracellular signal-regulated kinase (ERK) and PI3K pathway much like other RTKs (Zhang et al, 1999a; Zhang et al, 2000a; Srinivasa \& Doshi, 2002; Zhang et al, 1999b). Unlike in mice, where p85 binds FLT3 at Y958 in the carboxyl terminus, human FLT3 does not directly associate with the p85 subunit of PI3K. Instead, human FLT3 forms multifaceted associations with GRB2, GAB2, SHIP, SHP2, E3 ubiquitin-protein ligase (CBL) and E3 ubiquitin-protein ligase B (CBLB) which inevitably act on p85 (Zhang et al, 1999a; Zhang et al, 2000a). It was shown that tyrosine residues 572, 589, 591 and 599 are in vivo autophosphorylation sites and that Y599 and Y589 are association sites for signal relay molecules including the SRC family kinases and SHP2 (Heiss et al, 2006). Heiss et. al. (2006) hypothesized that the recruitment of SHP2 to pY599 contributes to FLT3L mediated Erk activation and proliferation.

Activation of FLT3 was also found to alter transcription via signal transducer and activators of transcription like signal transducer and activator of transcription (STAT) 5A (Zhang et al, 2000a). It has the ability to prevent expression of genes that induce apoptosis like BCL2associated X protein (BAX) (Lisovsky et al, 1996). Additionally, Pim-1, a proto-oncogene upregulated by STAT5, is associated with FLT3, and inhibition of FLT3 resulted in a 10x decrease of Pim-1 expression (Kim et al, 2005). The juxtamembrane domain of FLT3 is critical for PIM-1 upregulation and cell proliferation on BA/F3 cells, however it is independent of the $\mathrm{N}$-terminal 
region, which is normally responsible for STAT5, AKT and mitogen activated protein kinase (MAPK) phosphorylation (Krstovski et al, 2009). Also, the FLT3 gene promoter was suppressed by transcription factor PU.1, suggesting an inverse relationship between the two molecules (Inomata et al, 2006). The transcription factor controls dendritic cell (DC) development and flt3 cytokine receptor expression in a dose-dependant manner. As a result, PU.1 positive cells displayed reduced expression of flt 3 and impaired DC formation (Carotta et al, 2010). However, FLT3 pathways display high tissue and species specificity which may be a downfall when attempting to correlate results from murine cell lines to human haematopoietic cells (Zhang et al, 1999a; Dosil et al, 1993). 


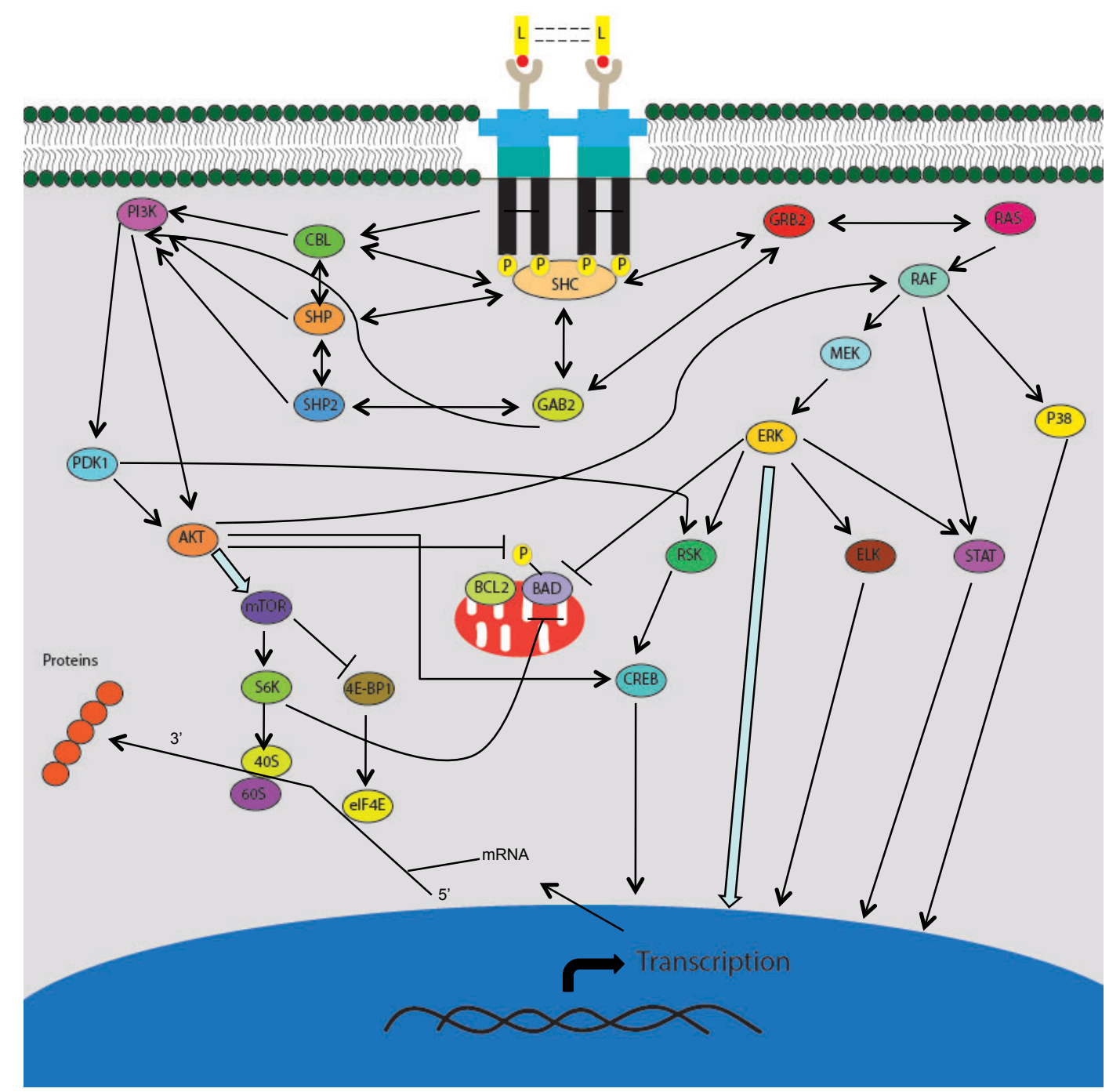

Figure 5. FLT3 signal cascade. Receptor-ligand binding triggers the PI3K and RAS pathways, resulting in increased cell proliferation and inhibition of apoptosis. PI3K activity is regulated through interactions between FLT3, SHC, SHIP, SHP2, CBL, and GAB2. Activated PI3K stimulates proteins such as 3-phosphoinositide-dependent protein kinase 1 (PDK1), protein kinase $\mathrm{B}(\mathrm{PKB} / \mathrm{AKT})$ and the mammalian target of rapamycin (mTOR), which initiate transcription and translation of regulatory genes through the activation of p70 S6 kinase (S6K) and the inhibition of eukaryotic initiation factor 4E-binding protein (4E-BP1). PI3K activation also blocks apoptosis through phosphorylation of BAD. FLT3 also associates with GRB2 through SHC, activating RAS. RAS activation stimulates RAF, MAPK/ERK kinases (MEKs), extracellular-signal-regulated kinase (ERK), and the ribosomal protein S6 kinase (RSK). These effectors activate cyclic adenosine monophosphate-response element binding protein (CREB), ELK and signal transducer and STATs which results in transcription of genes involved in proliferation. Black arrows depict direct associations between proteins and blue arrows indicate associations that are indirect. Image adapted from Stirewalt et al, 2003. 


\section{Biological significance of FLT3}

The activation of FLT3 in vitro causes growth of early progenitor cells (Ray et al, 1996; Veiby et al, 1996; Rusten et al, 1996). Currently, research suggests that FLT3 alone is unable to have a substantive effect on proliferation of early haematopoietic progenitor cells, but it does cause monocytic differentiation (Rusten et al, 1996; Gabbianelli et al, 1995). When FLT3 is activated in the presence of other growth factors like IL-3, granulocyte-colony stimulating factor (G-CSF), CSF1, GM-CSF, and KIT ligand, a stronger proliferative response occurs with more granulocytic-monocytic colony forming units being produced (Gabbianelli et al, 1995; Rusten et al, 1996; Shah et al, 1996). Of these other growth factors, the most potent combination has been seen with FLT3L, KIT ligand and IL-3 (Rusten et al, 1996). Since FLT3 is not found in megakaryocytes and erythrocytes, FLT3L has no effect on those cell lines (Gabbianelli et al, 1995). FLT3L stimulation in combination with IL-7 and IL-11 results in long-term clonal expansion and differentiation of murine haematopoietic progenitor cells (Ray et al, 1996). In fetal human bone marrow, FLT3L with IL-7 encourages stromal-cell-independent growth of proB cells and their differentiation to pre-B cells (Namikawa et al, 1996). Deleting IL-7 caused adult B-cell development cessation while fetal cell development continued in mice models. Additionally, residual B-cells in IL-7 receptor deficient mice required FLT3 for development indicating that IL-7 and FLT3 are needed to produce the majority of B lymphocytes (Vosshenrich et al, 2003). There is also a synergistic effect between FLT3L and G-CSF that causes mobilization of stem cells into the blood serum (Streeter et al, 2003). Proliferation and differentiation of T-cells are also affected by FLT3 activation (Hannum et al, 1994; Moore et al, 1997). Also, FLT3 has been shown to be a negative regulator of IL-10, an anti-inflammatory cytokine secreted by $\mathrm{T}$ cells (Astier et al, 2010). The FLT3 receptor with its ligand normally activates T cells, however when FLT3 was silenced, there was an increase in IL-10 levels (Astier et al, 2010). Alternatively, when FLT3L was added, IL-10 was suppressed while FLT3 receptor levels were increased (Astier et al, 2010). Additionally, engagement of CD46 regulatory type 1 cells also resulted in an increase in the FLT3 surface receptor and secreted FLT3L which led to the inhibition of IL-10 production (Astier et al, 2010). Together the results indicate that the FLT3 pathway forms a regulatory feedback loop resulting in decreased IL-10 in T-cells (Astier et al, 2010). 
The FLT3 ligand is a potent stimulator of granulocyte-macrophage colony-stimulating factor (GM-CSF), interleukin-3 (IL-3), or G-CSF-dependent granulocyte-macrophage committed precursors from Lin- CD34+ bone marrow cells (Piacibello et al, 1995). Although synergistic effects were seen with various combinations of G-CSF, GM-CSF, IL-3, or SCF; FLT3L alone induced and increased colony formation by clonogenic precursor cells (Piacibello et al, 1995; Daro et al, 2002). By contrast, FLT3L does not affect the growth of erythroid-committed progenitors even with the addition of EPO (Piacibello et al, 1995).

When comparing FLT3L free stimulation with FLT3L in combination with IL-3, IL-6, and IL-7, there is a two to six fold increase in the amount of primitive thymic progenitors (Moore et al, 1997). In murine knockout studies, FLT3 deficient mice displayed little or no morphological bone marrow changes and fairly normal haematopoiesis except for a small reduction in pro and pre-B cell compartments (Mackarehtschian et al, 1995). Knockouts of both KIT and FLT3 proved to be fatal due to haematopoietic complications. As a result, it is evident that FLT3 plays an important role in haematopoiesis but that this role is not total, as it must cooperate with other growth factors to illicit a full differentiation and proliferative response in myeloid and lymphoid cells (Mackarehtschian et al, 1995). This is clinically relevant as one may inhibit FLT3 in leukemic conditions without the patient encountering too severe haematopoietic side-effects.

After the success of FLT3L working synergistically with many interleukins, interleukin16 (IL-16) and 18 (IL-18) were analyzed. Interluekin-16 was added to a cocktail comprised of granulocyte-macrophage colony-stimulating factor (GM-CSF), interluekin-4 (IL-4), FLT3L and TACE (Della Bella et al, 2004). This combination was able to induce the CD34(+) hematopoietic cells to proliferate in vitro and to differentiate into phenotypically and functionally mature DCs (Della Bella et al, 2004). Furthermore, tumors of mice were injected with FLT3L, IL-18, or a combination of both and it was found that FLT3L alone was able to eliminate the tumors more than IL-18 alone (Saito et al, 2008). Additionally, the lymphoid cells in the lymph nodes of the mice had significant cytolytic activity against the tumor cells (Saito et al, 2008). The combination of FLT3L and IL-18 caused recruitment of mobilized DC into the tumor bed and a more potent allogeneic $\mathrm{T}$ cell stimulation (Saito et al, 2008). Antigen-presenting dendritic cell development is also promoted by FLT3 activation which leads to clonal expansion of dendritic 
cells in bone marrow, spleen, lymph nodes and blood serum (Saunders et al, 1996; Maraskovsky et al, 1996; Morse et al, 2000). This finding suggests FLT3L stimulation may boost immune response to tumors and is supported by evidence indicating a reduction in murine solid and haematopoietic tumors. The same studies done in humans have shown mixed response (Lynch et al, 1997; Chen et al, 1997; Chakravarty et al, 1999; Pawlowska et al, 2001; Parajuli et al, 2001). Furthermore, there seems to be a co-expression of FLT3 and Meis1, a transcription factor oncoprotein often expressed with Homeobox A9 (Hoxa9) in AML (Wang et al, 2005).

Overexpression of Meis1 results in increased FLT3 transcription which then synergizes with NUP98-HOX to increase proliferation of myeloid progenitors blocked in differentiation by NUP98-HOX fusion (Palmqvist et al, 2006). This indicates that FLT3 has a direct role in an AML outcome. In vivo, overexpression of FLT3L expands splenic natural killer dendritic cells (NKDC) from 2 to 18 fold (Zhang et al, 2009). These cells are able to secrete IFN-gamma, directly lyse tumor cells, and can present antigens to $T$ cells, thereby having immunotherapeutic potential (Zhang et al, 2009). The FLT3L induced expansion of the cells result in NKDC with a more mature phenotype and a slightly increased ability to capture and process antigen (Zhang et al, 2009). Overall, FLT3L has been found to be the most potent growth factor for DC generation both in vitro and in vivo, resulting in its continued research in immunotherapy due to its ability to present tumor antigens to T-cells and irradiate tumors (Zhang et al, 2005).

\section{FLT3 mutations and effects}

FLT3 mutations were first described in by Nakao et al (1996). The most common mutation is a internal tandem duplication (ITD) in exons 14 and 15 (Nakao et al, 1996). This mutation occurs in 15-35\% of AML patients and 5-10\% of MDS patients (Horiike et al, 1997; Xu et al, 1999; Kiyoi et al, 1999; Kottaridis et al, 2001; Yokota et al, 1997; Brown et al, 2004). The ITD phenotype occurs when a portion of the juxtamembrane region sequence is duplicated and inserted head to tail (Schnittger et al, 2002). The reading frame is conserved and the ITD can vary from 3 to greater than $400 \mathrm{bp}$ (Schnittger et al, 2002). These ITD mutations result in ligandindependent dimerization causing auto-phosphorylation and continuous receptor activation (Kiyoi et al, 1998; Hayakawa et al, 2000; Kiyoi et al, 2002; Mizuki et al, 2000). How this mutation mediates constitutive activation is currently unknown, however it is thought that the 
mutation in the juxtamembrane region may result in a loss of the regions that prevent FLT3 ligand dependent dimerization (Kiyoi et al, 2002). The mutated receptor is shown to dimerize and activate wildtype FLT3 even in the absence of a tyrosine kinaase domain (TKD) (Kiyoi et al, 2002). Similar mutations with constitutive signalling have been documented in vascular endothelial growth factor receptor 1 (VEGFR1) (Gille et al, 2000). These internal duplications may also alter the monomeric receptor conformation to expose the phosphoryled acceptor sites in the TKD which causes the ligand to dock and activate the receptor causing activation without dimerization (Kiyoi et al, 1998; Hayakawa et al, 2000; Kiyoi et al, 2002; Zheng et al, 2002) This continuous activation causes proliferation and blocks myeloid differentiation of early haematopoietic cells in mice (Kiyoi et al, 1998; Hayakawa et al, 2000; Kiyoi et al, 2002; Zheng et al, 2002).

In other murine studies, FLT3 ITDs altered the myeloproliferative phenotype but did not cause a clear acute leukemic state (Kelly et al, 2002a). It is thought that FLT3 mutations are one of two possible synergistic causes of leukemias. Although FLT3 mutations alter differentiation, proliferation and apoptosis, there is significant intersection of intracellular pathways that might cause a single FLT3 mutation to disrupt multiple pathways (Kiyoi et al, 1998; Hayakawa et al, 2000; Mizuki et al, 2000; Zheng et al, 2002; Kelly et al, 2002b). Based on Knudson's 'two hit' theory (cancers are caused by at least two mutations), FLT3 inhibition therapy may only partially treat a haematopoietic malignancy (Knudson et al, 1975).

In addition to continuous signalling, the components involved in the signal cascades themselves are altered with a FLT3 ITD (Mizuki et al, 2000). Instead of eliciting a weak phosphorylation of STAT5 and lack of subsequent DNA binding, mutated FLT3 ITD does the opposite (Mizuki et al, 2000). Additionally, using siRNA, it was demonstrated that silencing FLT3 results in RAD51 downregualtion in FLT3-ITD cells but not in the WT cells (Seedhouse et al, 2006). Furthermore, cells with FLT3 ITDs display decreased expression profiles of PU.1 and CCAAT/enhancer-binding protein alpha $(\mathrm{C} / \mathrm{EBP} \alpha)$, two proteins involved in regulation of haematopoietic cell differentiation and proliferation (Mizuki et al, 2002). The FLT3-ITD mutation was also found to suppress SHP-1, and CXCR-4 expression was significantly higher in FLT3-ITD AML than in wildtype FLT3 AML (Chen et al, 2005; Rombouts et al, 2004). Also, a particular FLT3L-Y591 duplication signalling in AML enables accumulation of B-cell 
lymphoma 2 (Bcl-2) and maintains a downstream block of p53 pathway apoptosis (Irish et al, 2007). Furthermore, FLT3-ITD up-regulates myeloid cell leukemia-1 (MCL-1), a survival factor for hematopoiesis expressed by hematopoietic stem cells (Yoshimoto et al, 2009). Myeloid cell leukemia-1 is expressed at its highest in response to FLT3 signalling, however when mutated, FLT3-ITD results in even higher MCL-1 expression by interfering with its signal transducer and STAT5-docking domains in AML cell lines, resulting in prolonged cell survival and reduced apoptosis (Yoshimoto et al, 2009). When tyrosine kinase inhibitors were introduced or STAT5 activation blocked, MCL-1 production decreased and apoptosis commenced (Yoshimoto et al, 2009). Nucleophosmin 1 (NPM1) mutations in AML patients were found to correlate with FLT3ITD, with a favourable outcome in AML cases that did not have the FLT3-ITD in addition to the NPM1 mutation (Luo et al, 2010). FLT3-ITD and point mutations in the kinase domain, as well as mutation in NPM1 are the most common abnormalities in adult AML (Krstovski et al, 2009).

Overall, AML patients with FLT3-ITDs make up 5-15\% of paediatric and $25-35 \%$ of adult cases with mutations in the activating regions being the most frequent mutations (Meshinchi et al, 2001; Iwai et al, 1999; Kondo et al, 1999; Grundler et al, 2005). Clinically, ITDs are associated with an increase in white blood cells, high blast cell counts, and poor survival rates (Schnittger et al, 2002; Iwai et al, 1999; Kondo et al, 1999). A specific ITD mutation in the activation loop (Y842C) of AML patients causes cell proliferation and survival by playing a role in mediating FLT3 conformations (Kindler et al, 2005). In general, intracellular signals mediated by WT FLT3 are involved with cell differentiation and survival, whereas signalling via FLT-ITD results in enhanced cell growth (Masson et al, 2009).

Other mutations consist of a missense point mutation in exon 20 in the TKD. This type of mutation occurs in 5-10\% of AML cases, $2-5 \%$ of MDS and 1-3\% of ALL cases (Thiede et al, 2002; Yamamoto et al, 2001; Abu-Duhier et al, 2001). The most common mutation changes an aspartic acid to tyrosine (GAT $\rightarrow$ TAT) D835Y and maintains the reading frame (Thiede et al, 2002; Yamamoto et al, 2001; Abu-Duhier et al, 2001). Like ITD mutations, TKD mutations cause receptor phosphorylation and cell growth without stimulation by FLT3L. These TKD mutations are also seen in other RTK3 family members like KIT which has about $80 \%$ similarity to the FLT3 TKD (Yamamoto et al, 2001; Spiekermann et al, 2002). Although currently unknown, TKD mutations possibly alter the level of tyrosine kinase activity depending on which 
amino acid is substituted (Kiyoi et al, 2002; Morley et al, 1999; Moriyama et al, 1996). Unfortunately, since TKD mutations occur less frequently, large scale studies are difficult to conduct and like the FLT3 ITD, studies often start after a diagnosis of leukemia and post initial treatment. However, it is noted that FLT3 with TKD mutations are often overexpressed and patients often have a reduction in overall survival (Thiede et al, 2002; Libura et al, 2003).

Much less common mutations also occur in and around codon 835, such as deletions with additional codon alterations while maintaining the reading frame (Thiede et al, 2002; Yamamoto et al, 2001; Spiekermann et al, 2002). Most haematopoietic malignancies only have one mutation. It is rare, but possible, to have two mutations at once (Thiede et al, 2002; Meshinchi et al, 2003). The TKD and ITD mutations together, are the greatest cause of genetically modified AML as evidenced by the $25-45 \%$ of AML cases with either mutation (Meshinchi et al, 2003). However, studies that indicate the aforementioned effects in relation to AML and ALL patients are not as accurate as studies that are done with consistent patient treatment and analysis.

\section{Clinical significance of FLT3 and the use of inhibitors}

Although treatment plans are based on level of risk (very low-very high), leukemia patients with similar characteristics and risks often experience different side effects during chemotherapy. Further knowledge of the role that various types of ITDs and TKD mutations play in leukemia may provide greater insight into risk characterization. In recent years, small molecule tyrosine kinase inhibitors seem to be a promising area of treatment for many malignancies. Since FLT3 is involved in many leukemias, the receptor and its downstream molecules are an attractive target for inhibitors. Cephalon makes two FLT3 tyrosine kinase inhibitors; CEP-701 and CEP-5214, each derived from indolocarbazole, that inhibits both wildtype and mutant FLT3. Recently, CEP-701 was found to be toxic to leukemia blasts, to increase survival rate in mice, and has shown some inhibition against KIT, PDGFR, and FMS (Levis et al, 2001). Sugen Life Sciences has also developed several inhibitors such as SU5416, SU5614 and SU11248 blocking FLT3 along with KIT, PDGFR and VEGFR (O'Farrell et al, 2003; Yee et al, 2002; Foran et al, 2002). Millennium Sciences produced MLN518, a piperarazinyl quinazoline that inhibits growth of FLT3-ITD transformed cells along with 
PDGFR and KIT (Kelly et al, 2002c). Novartis Canada has made PKC412, a benzoylstaurosporine, to inhibit VEGF and both wildtype and mutant FLT3 (Armstrong et al, 2002; Weisberg et al, 2002). In 2004, a bi-aryl urea BAY 43-9006 inhibitor of v-raf-1 murine leukemia viral oncogene homolog (RAF-1), a common downstream target of FLT3, also demonstrated FLT3 inhibition along with inhibition of other RTK3 family members (Wilhelm et al, 2004). Additionally, general tyrosine kinase inhibitors like PKC412, are able to inhibit mutated FLT3, as seen with evidence of inhibition of Y842C ITD mutated FLT3 in AML patients (Grundler et al, 2005). All of these FLT3 inhibitors show mixed success and are not widely in clinical use, but seem extremely promising, especially in treatment of aggressive leukemias caused by FLT3 mutations that could otherwise be lethal.

\section{Previous attempts to express and purify FLT3L}

Lyman et al. (1993b) was the first group to clone the ligand for the FLT3 receptor from a murine T-cell line (P7B-0.3A4). The cDNA clone of the ligand obtained from an expression library was isolated and when transfected into cells, was able to bind to soluble FLT3 causing the proliferation of murine and human bone marrow cells and murine fetal liver cells that were enriched with hematopoietic stem cells and uncommitted progentior cells (Lyman et al, 1993b). PCR was used to amplify the extracellular coding domain of FLT3L between the end of the signal peptide and the start of the transmembrane segment (Lyman et al, 1993b). A FLAG sequence was added to the N-terminus of the ligand, with a termination codon placed after Gln189 before beginning the transmembrane region (Lyman et al, 1993b). The DNA fragment was then ligated into the yeast Kluyveromyces lactis (K. lactis) for secretion of the ligand into the yeast medium (Lyman et al, 1993). The FLAG-flt31 was purified via affinity chromatography from the yeast supernatant for use in subsequent activity assays. Murine fetal liver cells (AA4.1+, Sca-1+, Lin $^{\text {low }}$ ) with detectable levels of FLT3 were cultured in either $100 \mathrm{ng} / \mathrm{ml}$ IL-7 and $250 \mathrm{ng} / \mathrm{ml} \mathrm{FLT3L}$ or $1 \mathrm{ug} / \mathrm{ml}$ steel factor (SLF) with $250 \mathrm{ng} / \mathrm{ml}$ FLT3L (Lyman et al, 1993b). Based on a $\left[{ }^{3} \mathrm{H}\right]$ thymidine incorporation assay after 5 days incubation, the overall mitotic response of the cells with FLT3L alone was 8x that of cells with no factor added (Lyman et al, 1993b). With IL-7 added in conjunction with FLT3L, the proliferative response was two times greater than IL-7 alone, which had no response at all (Lyman et al, 1993b). The 
combination of SLF and FLT3L produced a proliferative response 3x that of SLF alone which had a response of 14x that of cells with no factor added (Lyman et al, 1993b). Thus, it was concluded that although FLT3L does have significant activity alone, it works synergistically with other factors such as SLF and IL-7 to produce an even greater hematopoietic cell response (Lyman et al, 1993b).

In 2005, Zhang et al. cloned FLT3L in the Pichia pastoris (P. pastoris) system and were able to get a yield of $30 \mathrm{mg} / \mathrm{L}$ of recombinant FLT3L with a purity of 95\% utilizing dialysis, filtration and anion-exchange steps. A synthetic DNA fragment was constructed based on $P$. pastoris biased codon usage encoding soluble human FLT3L, supernatant was analysed for expression of FLT3L and dialyzed against $20 \mathrm{mM}$ Tris- $\mathrm{Cl} \mathrm{pH} 8.0$ with a molecular weight cut off of $12 \mathrm{kDa}$ and filtered through a $0.45 \mathrm{um}$ filter (Zhang, 2005). After application to an anionexchange column, bound protein was eluted with a linear salt gradient (Zhang, 2005). Fifty millilitre fractions were concentrated to $5 \mathrm{~mL}$ using a freeze drier and the concentrate was applied to a Sephacryl S-200 gel filtration column (Zhang, 2005). Both a low (LMW) and high molecular weight (HMW) fraction was isolated and the low weight fraction was collected and analysed by reverse phase HPLC to be the recombinant FLT3L (Zhang, 2005). The purified protein was treated with $1 \mathrm{mU}$ Endo $\mathrm{H}$ and subsequently analysed by western blotting (Zhang, 2005). The low molecular weight fraction appeared to be FLT3L at a molecular weight of $21 \mathrm{kDa}$ while the higher weight fraction of $34 \mathrm{kDa}$ also appeared to be a different form of FLT3L with a different set of carbohydrate components (Zhang, 2005). After Endoglycosidase H was used to remove N-linked glycosylation, both the HMW and LMW bands seen in the Western blot were at a lower molecular weight, however the weight was still higher than seen in recombinant FLT3L produced in E.coli, indicating that other post-translational modifications had occurred (Zhang, 2005). The $\mathrm{pI}$ of the $21 \mathrm{kDa}$ recombinant FLT3L was determined to be between 3.12 4.72 (Zhang, 2005). Cell activity was measured by using the $21 \mathrm{kDa}$ FLT3L on nucleated bone marrow cells derived from mice. GM-CSF (100 ng/ml) was used in conjunction with several concentrations of FLT3L (0-100 ng/ml) (Zhang, 2005). Alone, FLT3L showed a weak response, but with the addition of GM-CSF, and increasing concentrations of FLT3L, enhanced cell expansion was seen in a dose-dependant manner (Zhang, 2005). 
In 2010, Zhao et al. (2010) attempted to express, purify and characterize FLT3L in E.coli. The were able to express the extracellular domain of recombinant human FLT3L as a thioredoxin (Trx) fusion protein (Zhao et al, 2010). The protein however, was insoluble and expressed only in inclusion bodies that were refolded and purified using dialysis and affinity chromatography (Zhao et al, 2010). They subsequently tested the recombinant FLT3L on murine bone marrow nucleated cells to obtain a proliferation assay and colony forming assay (Zhao et al, 2010). The original cloning vector was pET32a $(+)$ and expression was done in E. coli BL21 (Zhao et al, 2010). Purification was completed using the ProBond ${ }^{\mathrm{TM}}$ Purification System (Invitrogen) while refolding and dialysis of the purified protein was done simultaneously in the dialysis bag (Zhao et al, 2010). Bone marrow cells were isolated from C57BL/6 mice and the purified Trx-FLT3L or Trx alone was added to the cell media at a concentrations of $0,0.1,1,10$, 100 and $1000 \mathrm{ng} / \mathrm{mL}$ (Zhao et al, 2010). Cells were cultured for one week. A MTT colorimetry and colony-forming assay was done (Zhao et al, 2010). Results indicate that Trx-FLT3L was dramatically effective past $10 \mathrm{ng} / \mathrm{mL}$ compared to the Trx controls. At $1 \mathrm{ug} / \mathrm{mL}$ about 42 colonies were seen as opposed to 9 in the Trx control (Zhao et al, 2010).

As demonstrated by the above attempts to express and purity a soluble form of FLT3L, it is challenging to produce this cytokine (Table $1 \& 2$ ). Since FLT3L is a transmembrane protein with the cytosolic and transmembrane portions unnecessary for function, when expressing the protein it is useful to only express the extracellular portion of the protein which is both soluble and functional (Lyman et al, 1998). It seems the best species to produce the ligand, is yeast. When attempting to express FLT3L in E.coli, the protein is always found in inclusion bodies and needs to be denatured and refolded to produce the finished product. Not only is this time consuming and difficult to accomplish, but often when this occurs, proteins are misfolded and their original functionality is lost (Cox \& Nelson, 2008). Secondly, unlike E.coli, yeast is able to glycosylate the ligand and perform other post-translational modifications that may be necessary for its function both in vitro and in vivo (New England Biolabs, 2011). Natively, FLT3L is heavily glycosylated, adding as much as $13 \mathrm{kDa}$, as seen in the work of Zhang et al. (Zhang et al, 2005). Also, FLT3L can be glycosylated to varying degrees, however the literature currently does not indicate the exact amount of $\mathrm{N}$ and $\mathrm{O}$ linked glycosylation that occurs in each species. Furthermore, in all expression papers, dialysis was used to remove any contaminants and to adjust the $\mathrm{pH}$ when working with yeast strains that may produce acidic by-products (Lyman et al, 
1993a; Zhang et al, 2005; Xu et al, 2000). One problem with expressing in yeast such as $K$. lactis, is the very low $\mathrm{pH}$ of the media which may interfere with protein purification when using such tags as histidine, as it would become a weak acid (around $\mathrm{pH} 4$ ) resulting in it being protonated and unble to bind metal from affinity chromatography columns, thus preventing purification of the protein (Cox \& Nelson, 2008). To counter this, dialysis must be done to increase the $\mathrm{pH}$ to optimal HIS-tag binding conditions ( $\mathrm{pH} 7$ ).

As seen in the cases above, activity of recombinant human and mouse FLT3L has been shown to be effective in proliferating nucleated mouse bone marrow cells at as low a concentration as $10 \mathrm{ng} / \mathrm{mL}$, making the ligand extremely potent (Zhang et al, 2005). Additionally, it is able to function both on its own and synergistically with other factors such as SLF, IL-7 and GM-CSF with a proliferative response occurring in about 3-7days (Lyman et al, 1993a). 
Table 1. Summary of FLT3L expression papers.

\begin{tabular}{|c|c|c|c|c|c|c|}
\hline Author/Year & FLT3L & $\begin{array}{c}\text { Expression } \\
\text { System }\end{array}$ & Purification & $\begin{array}{c}\text { Molecular } \\
\text { Weight }\end{array}$ & $\begin{array}{l}\text { Post- } \\
\text { translational } \\
\text { Modifications }\end{array}$ & Activity \\
\hline Lyman et al, 1993b & $\begin{array}{l}\text { Extracellular domain } \\
\text { of murine FLT3L } \\
\text { (between end of signal } \\
\text { peptide, and start of } \\
\text { transmembrane } \\
\text { sequence) }\end{array}$ & K. lactis & $\begin{array}{l}\text { FLAG-flt31 purified } \\
\text { via affinity } \\
\text { chromatography from } \\
\text { yeast supernatant }\end{array}$ & $23.16 \mathrm{kDa}$ & $\mathrm{N} / \mathrm{A}$ & $\begin{array}{l}\text { AA4.1+, Sca-1+, Lin }{ }^{\text {low }} \text { murine } \\
\text { fetal liver cells cultured in } \\
250 \mathrm{ng} / \mathrm{mL} \text { FLT3L for } 5 \text { days } \\
\text { showed proliferative response. }\end{array}$ \\
\hline Zhang et al, 2005 & $\begin{array}{l}\text { Artificial synthesized } \\
\text { human recombinant } \\
\text { FLT3L gene }\end{array}$ & P. pastoris & $\begin{array}{l}\text { Dialysis, filtration, } \\
\text { anion-exchange step., } \\
\text { Sephacryl S-200 and } \\
\text { reverse-phase HPLC }\end{array}$ & $\begin{array}{l}21 \mathrm{kDa} \\
34 \mathrm{kDa}\end{array}$ & $\begin{array}{l}\text { N-linked } \\
\text { glycosylation } \\
\text { O-glycosylation? }\end{array}$ & $\begin{array}{l}\text { Dose dependant restorative } \\
\text { activity of FLT3L }(0-100 \mathrm{ng} / \mathrm{mL}) \\
\text { on nucleated bone marrow cells } \\
\text { derived from mice. }\end{array}$ \\
\hline Zhao et al, 2009 & $\begin{array}{l}\text { Extracellular domain } \\
\text { of recombinant human } \\
\text { FLT3L }\end{array}$ & E. coli (BL21) & $\begin{array}{l}\text { 6HIS-FLT3L-Trx } \\
\text { fusion protein was } \\
\text { insoluble and } \\
\text { expressed in } \\
\text { inclusion bodies that } \\
\text { were refoldeded/ } \\
\text { purified using } \\
\text { ProBond } \\
\text { Purification System } \\
\text { and dialysis. }\end{array}$ & $36.7 \mathrm{kDa}$ & $\mathrm{N} / \mathrm{A}$ & $\begin{array}{l}\text { FLT3L }(0-100 \mathrm{ng} / \mathrm{mL}) \text { tested on } \\
\text { bone marrow cells of C57BL/6 } \\
\text { mice.Trx-FLT3L was } \\
\text { dramatically effective on } \\
\text { increasing proliferation past } \\
10 \mathrm{ng} / \mathrm{mL}\end{array}$ \\
\hline
\end{tabular}


Table 2. Summary of FLT3L expression papers (Full articles unavailable, foreign journals)

\begin{tabular}{|c|c|c|c|c|c|c|}
\hline Author/Year & FLT3L & $\begin{array}{c}\text { Expression } \\
\text { System }\end{array}$ & Purification & $\begin{array}{c}\text { Molecular } \\
\text { Weight }\end{array}$ & $\begin{array}{c}\text { Post- } \\
\text { translational } \\
\text { Modifications }\end{array}$ & Activity \\
\hline Xu et al, 2000 & $\begin{array}{l}\text { Artificial synthesized } \\
\text { human recombinant } \\
\text { FLT3L gene }\end{array}$ & P. pastoris & N/A & N/A & N/A & $\begin{array}{l}\text { FLT3L stimulated colony } \\
\text { formation from cord blood, In } \\
\text { vitro expansion of } \\
\text { stem/progenitor cells and } \\
\text { increased the induction of } \\
\text { dendritic cells from cord blood. }\end{array}$ \\
\hline Zheng et al, 2001 & $\begin{array}{l}\text { Recombinant human } \\
\text { FLT3L }\end{array}$ & E. coli & $\begin{array}{l}\text { 6HIS-FLT3L } \\
\text { expressed in } \\
\text { inclusion bodies were } \\
\text { isolated, solubilized } \\
\text { and refolded. Then } \\
\text { purified by } \\
\text { chromatography on a } \\
\text { metal-chelating } \\
\text { affinity column }\end{array}$ & N/A & N/A & Expanded CD34+ cells in vitro \\
\hline
\end{tabular}




\section{Activity in other cell lines}

Since FLT3 is clinically important in AML cases, FLT3L has been tested with various AML cell lines. Drexler H. et al. (1999) conducted a comprehensive activity assay on many AML cell lines using $\left[{ }^{3} \mathrm{H}\right]$-thymidine incorporation. The strongest responses for cell proliferation were seen in the MUTZ-2 and OCI-AML5 cell lines (Drexler et al, 1999). Co-stimulation of primary AML cell lines was seen with FLT3L in addition to G-SCF, GM-SCF, IL-3, M-CSF, PIXY-321 and SCF, but not EPO (Drexler et al, 1999). Furthermore, IL-4 was found to inhibit the proliferative signal of FLT3L. Both OCI-AML5 and MUTZ-2 cell lines showed increased proliferation when exposed to 50,100, and 200ng/mL of FLT3L with markedly increased responses when combined with other growth factors such as M-CSF (Drexler et al, 1999). Additionally, OCI-AML5 cells, an AML cell line, proliferates in part, due to the activation of both ERK and p38 MAPK pathways in response to G-CSF and FLT3L (Srinivasa \& Doshi, 2002). Teleshova et al. (2004) administered human FLT3L in vivo to macaques to determine the extent of mobilization of dendritic cells (DC). After treatment with FLT3L (100 ug/ $\mathrm{kg} /$ day) for 5-7 days, DC's were mobilized and the DC frequency continued to escalate even past the seventh day of treatment (Teleshova et al, 2004). Dendritic cells analyzed within the lineage-human leukocyte antigen-DR+ cells including CD11c-CD123+ plasmacytoid DC's, CD11c+CD123myeloid and CD11c-CD123-cells (Teleshova et al, 2004). There have since been many experiments done to determine the effectiveness of FLT3L on various blood cell lines, however FLT3L has never been tested on RAW264.7 cells, a mouse leukaemic monocyte macrophage cell line. If FLT3L activates RAW264.7 cells their morphology would appear to be flattened, spread out and highly vacuolated which are all characteristics of a dendritic cell phenotype (Haak-Frendscho et al, 1990). 


\section{RATIONALE}

Cell signalling controls each function within the cell including differentiation, growth, proliferation and apoptosis. Receptors on the surface of cells interact with their ligands to illicit an intracellular response which controls the activity of the cell (Cox \& Nelson, 2008). Ligandreceptor complexes such as FLT3-FLT3L are of great importance because they control the cell life cycle. When these receptors become mutated, they often result in uncontrolled cell signalling and a diagnosis of cancer (Cox \& Nelson, 2008). In the case of the FLT3 receptor complex, mutated FLT3 contributes to continuous proliferation and a decrease in apoptosis of blood cells leading to a leukemic condition (Lyman et al, 1994b). Techniques such as LARC can be used in combination with mass spectrometry to provide more insight into the intramolecular signal sequence triggered by FLT3L in order to fully understand the cause of uncontrolled cell signalling leading to cancer (Jankowski et al, 2008). In order to complete multiple trials of LARC experiments, a source of the active form of the desired ligand must be obtained. The purpose of this thesis was to clone, express and purify a truncated, soluble form of FLT3L for use in subsequent LARC experiments to determine if there are any binding partners to FLT3L in blood and human myeloid leukemia models. 


\section{MATERIALS AND METHODS}

\section{Reagents}

FLT3L murine cDNA was purchased from American Type Culture Collection (ATCC \#69286). DH5 $\alpha$ cells are from Inivtrogen. All primers were ordered from Integrated DNA Technologies (IDT) unless otherwise stated. All DNA sequencing was done at MaRS (Toronto, ON). Primary antibody, Mouse Flt-3 Ligand Affinity Purified Polyclonal Ab, Goat IgG was purchased from R\&D Systems (AF427). Secondary antibody, Peroxidase-AffiniPure Donkey Anti-Goat IgG $(\mathrm{H}+\mathrm{L})$, was purchased from Jackson ImmunoResearch Laboratories INC (705035-003). K. lactis Protein Expression Kit containing; K. lactis GG799 Competent Cells, Integration Primer Set, NEB Yeast Transformation Reagent, NEBuffer 4 (10X), pKLAC1-malE Control Plasmid, pKLAC2 Vector, SacII and Yeast Medium Pack, was purchased from New England Biolabs (NEB, E1000S). Restriction enzymes EcoRI and XhoI were purchased from NEB (R0101L, R0146L). T4 DNA Ligase was purchased from Fermentas (EL0011). HOTSTART Taq DNA Polymerase, DNTPs and 10x buffer were purchased from BioShop Canada Inc (TAQ004.250). Dialysis tubing, 3.5K MWCO, was purchased from Thermo Scientific (68035). Mini-prep plasmid purification kit, QIAprep Spin Miniprep Kit, and QIAquick Gel Extraction Kit were purchased from Qiagen (27104, 28704). Molecular weight protein ladders used were the Ultra low range marker purchased from Sigma-Aldrich (M3546) and precision plus protein all blue standards purchased from BioRad (\#161-0373). The DNA ladder used for $1 \%$ agarose gels was GeneRuler ${ }^{\mathrm{TM}} 1 \mathrm{~kb}$ plus DNA ladder from Thermo-Scientific (SM1331). Protease cocktail inhibitor was from Sigma-Aldrich (P8340).

Primary antibody used for RAW264.7 cells was Anti-FLT3 mouse, rabbit polyclonal IgG (Santa Cruz Biotechnology Inc, H-300), targeting the epitope at the C-terminus of murine FLT3. Secondary antibody used was goat, anti-rabbit IgG, HRP (Jackson ImmunoResearch Laboratores Inc, 111-035-003). Staining for RAW264.7 cells was done with Alexa Fluor 488® phalloidin (Invitrogen, A12379). All other chemicals were from bioshop unless otherwise stated. 


\section{Experimental Procedures}

\section{Cloning of FLT3L in E.coli}

Murine FLT3L cDNA in E.coli DH10B was purchased from ATCC in lyophilized form and resuspended in LB media containing $50 \mathrm{mg} / \mathrm{mL}$ ampicillin (amp). E.coli was grown overnight at $37^{\circ} \mathrm{C}$ with shaking at $250 \mathrm{rpm}$. Plasmid mini-preparation was preformed as per QIAprep kit instructions to purify the pDC406 construct containing FLT3L cDNA. Purified pDC406 (1.2ug) was digested by EcoRI or BamHI (BamHI 20U, 1x NEBuffer 3 (50 mM Tris$\mathrm{HCl}, 100 \mathrm{mM} \mathrm{NaCl}, 10 \mathrm{mM} \mathrm{MgCl} 2,1 \mathrm{mM}$ Dithiothreitol, pH 7.9), 1.2ug pDC406) (EcoRI 20U, 1x NEBuffer EcoRI (100 mM Tris-HCl, 50 mM NaCl, 10 mM MgCl $2,0.025$ \% Triton X-100, $\mathrm{pH} 7.5), 1.2 \mathrm{ug} \mathrm{pDC} 406$ ) overnight at $37^{\circ} \mathrm{C}$ to determine whether the correct size fragments of $7.5,6.4,3.4,1.1$, and $1.1 \mathrm{~kb}$, were produced.

\section{PCR and primer design}

Primers were designed to amplify the extracellular domain of FLT3L starting from just after the native signal sequence at T18 and ending before the transmembrane region at R188. Total amplified FLT3L region was 161 amino acids. Two primer sets were made, each with the forward primer containing a XhoI site next to a Kex region before the FLT3L cDNA region. The

reverse primers contained a stop codon just before a EcoRI site, with one having a 10HIS tag just before the stop codon.

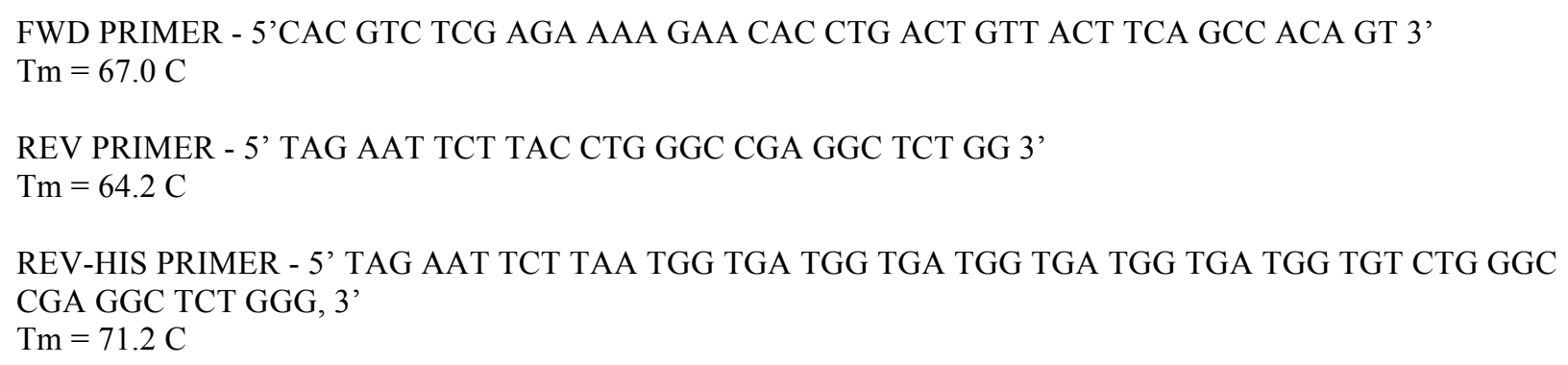

PCR was preformed according to: ( 5U Hotstart Taq DNA polymerase, 0.5uM FWD primer, 0.5uM REV primer or REV-HIS primer, 60.5ng pDC406, 200uM dNTPs, 1xPCR buffer (200mM Tris- $\mathrm{HCl} \mathrm{pH} \mathrm{8.4,} 200 \mathrm{mM} \mathrm{KCl})$ ). Reaction was preformed at $94^{\circ} \mathrm{C}$ for 3 min followed by 35 cycles of $94^{\circ} \mathrm{C} 1 \mathrm{~min}, 58^{\circ} \mathrm{C} 1 \mathrm{~min}, 72^{\circ} \mathrm{C} 1 \mathrm{~min}$, ending with $72^{\circ} \mathrm{C}$ for $10 \mathrm{~min}$. 


\section{Digestion, Ligation and Transformation}

Predicted size of the 10HIS product was $541 \mathrm{~kb}$ and the non-tagged product was $511 \mathrm{~kb}$. The PCR products, HIS-FLT3L and FLT3L, were cleaned as directed by QIAquick gel extraction kit and digested overnight at $37^{\circ} \mathrm{C}$ (XhoI 20U, EcoRI 20U, 1x NEBuffer 4 (20 $\mathrm{mM}$ Tris-acetate, $50 \mathrm{mM}$ potassium acetate, $10 \mathrm{mM}$ Magnesium Acetate, 1 mM Dithiothreitol, pH 7.9), $100 \mathrm{ug} / \mathrm{ml}$ BSA, 0.63 ug 10HIS-FLT3L DNA, or 0.72 ug FLT3L DNA). Approximately 1 ug pKLAC2 was also digested as previously described.

Digested HIS-FLT3L and FLT3L pcr products were each ligated to the digested pKLAC2 plasmid (7.5 U T4 ligase, 1xDNA ligase buffer ( $400 \mathrm{mM}$ Tris- $\mathrm{HCl}, 100 \mathrm{mM} \mathrm{MgCl} 2,100 \mathrm{mM}$ DTT, 5 mM ATP, pH 7.8), nuclease-free water, 100 ng pKLAC2, 50 ng FLT3L or 45 ng HISFLT3L) for $2 \mathrm{hrs}$ at room temperature. Approximately $3 \mathrm{uL}$ of the $10 \mathrm{uL}$ ligation reactions were used in the transformation of competent E.coli DH5 $\alpha$ cells by heat shock method described previously (Hanahan, 1983) and grown on LB agar plates containing $50 \mathrm{mg} / \mathrm{mL}$ amp. Several positive colonies of DH5 $\alpha$ cells containing either HIS-FLT3LpKLAC2 or FLT3LpKLAC2 were selected and grown overnight in LB media containing $50 \mathrm{mg} / \mathrm{mL}$ ampicillin (amp). After completing plasmid mini-prep on the selected colonies, they were screened further for positive ligation of FLT3L DNA by double digesting overnight with both XhoI and EcoRI as previously described to determine presence of insert (511kb FLT3L or 541kb HIS-FLT3L). In addition, positive transformants were sent to MaRS (Toronto, $\mathrm{ON}$ ) to be sequenced to confirm correct frame and sequence. Primers used for sequencing were adapted from the $K$. lactis Expression kit (NEB) and ordered from IDT.

Fwd sequencing 5' d(GAAGAAGCCTTGATTGGA) 3' Tm= 49.4 C

Rev sequencing 5' d(TTATCGCACAAGACAATC) 3' Tm=47.2 C

\section{Integration of plasmid into K.lactis}

FLT3LpKLAC2 and HIS-FLT3LpKLAC2 were both linearized over night at $37^{\circ} \mathrm{C}$ (SacII 20U, 1x NEBuffer 4 (50 mM potassium acetate, $20 \mathrm{mM}$ Tris-acetate, $10 \mathrm{mM}$ Magnesium Acetate, 1 mM Dithiothreitol, pH 7.9) , 1.4 ug FLT3LpKLAC2 or HIS-FLT3LpKLAC2). Integration of each lineraized contrust into K. lactis GG799 cells was done according to instructions by NEB K. lactis protein expression kit (\#E1000S). Transformants were selected by 
growth on Yeast Carbon Base (YCB) agar plates $(30 \mathrm{mM}$ Tris-HCl, $11.7 \mathrm{mg} / \mathrm{mL}$ YCB medium powder, $20 \mathrm{mg} / \mathrm{mL}$ Bacteriological agar) containing $5 \mathrm{mM}$ acetamide at $30^{\circ} \mathrm{C}$ for 2 days. Several colonies were picked and grown in YPGal medium $(10 \mathrm{mg} / \mathrm{mL}$ yeast extract, $20 \mathrm{mg} / \mathrm{mL}$ Bacteriological peptone, $40 \%$ galactose) for 3 days at $30^{\circ} \mathrm{C}$ with shaking $(250 \mathrm{rpm})$ to a final cell density of $>30 \mathrm{OD}_{600}$ units $/ \mathrm{ml}$. Properly integrated cells were confirmed by whole cell PCR as described by the NEB $K$. lactis protein expression kit using Integration primers 1 and 2, and analyzed on a $1 \%$ agarose gel to reveal a $2.4 \mathrm{~kb}$ product if integration was complete.

\section{Western Dot-blot}

A western dot-blot was done to determine whether the various strains were expressing FLT3L or HIS-FLT3L and also to determine the relative amount each was expressing. Approximately $2 \mathrm{uL}$ of supernatant was applied to a piece of polyvinylidene fluoride (PVDF) membrane wet with $100 \%$ methanol and left to dry. The PVDF was then soaked in $100 \%$ methanol, rinsed with water and blocked for 30 mins at room temperature with $5 \%$ milk solution in PBST with 1\% donkey serum. It was then washed once with TBST and the primary antibody, anti-murine FLT3L (R\&D systems), was applied (1:1000, $0.2 \mathrm{ug} / \mathrm{mL}$ ) for $30 \mathrm{~min}$ room temperature. After three 5min washes with TBST, the secondary antibody, donkey anti-goat HRP, was applied $(1: 10,000,0.026 \mathrm{ug} / \mathrm{mL})$ for $30 \mathrm{mins}$ at room temperature then washed $3 \times 5$ min. The PVDF membrane was developed using ECL western blot solution (100mM Tris pH 8.8, $250 \mathrm{mM}$ Luminol, $2 \mathrm{mM}$ IPBA) (Haan \& Iris, 2007). A strain of $K$. lactis that did not contain the insert was used as a control for all experiments.

\section{Purification of HIS-FLT3L}

Large batches of YPGal media were inoculated with $1 \mathrm{~mL} / 100 \mathrm{~mL}$ overnight starter culture and grown for 3 days at $30^{\circ} \mathrm{C}, 250 \mathrm{rpm}$ to a final cell density of $>30 \mathrm{OD}_{600} \mathrm{units} / \mathrm{ml}$. Media was then centrifuged $(8000 \mathrm{rpm}, 10 \mathrm{~min})$ and the pelleted cells and supernatant collected. 
Cells

Cell pellets were dried and resuspended in 1x phosphate buffered saline (PBS) (137 mM $\mathrm{NaCl}, 2.7 \mathrm{mM} \mathrm{KCl}, 4.3 \mathrm{mM} \mathrm{Na}_{2} \mathrm{HPO}_{4}, 1.47 \mathrm{mM} \mathrm{KH}_{2} \mathrm{PO}_{4}, \mathrm{pH}$ 7.4) containing protease cocktail inhibitor solution ( $5 \mathrm{mM}$ PMSF, $5 \mathrm{mM}$ SEBSF and $5 \mathrm{mM}$ EDTA). Cells were then homoginized in a French ${ }^{\circledR}$ Press (Thermo Spectronic). Homogenate was centrifuged for $60 \mathrm{~min}$ at $45000 \mathrm{x} \mathrm{g}$. The resulting supernatant and pellets were dried in a centrivap concentrator (Labconco) overnight and subjected to a discontinuous SDS-PAGE (4\% stacking, 9\% separating). About 40 $\mathrm{uL}$ of supernatant or pellet was added to $10 \mathrm{uL}$ 10x SDS-PAGE sample buffer and heated before being eletrophoresced. After transferring onto PVDF membrane, western blot was analysis was done as previously described using anti-murine FLT3L primary antibody (R\&D Systems).

\section{Supernatant}

Supernatant of the three strains of $K$. lactis (control, HIS-FLT3L, FLT3L strains) were dialyzed for 2 days against (10 mM Tris-Cl pH 8.0) (6 L, 7 buffer changes in total) to a final $\mathrm{pH}$ of 7.7-8.0. Dialysed HIS-FLT3L supernatant was loaded onto a Qiagen Ni-NTA Superflow column and the flowthrough collected. The column was washed with $4 \mathrm{~mL}$ wash buffer $(50 \mathrm{mM}$ $\mathrm{NaH}_{2} \mathrm{PO}_{4}, 300 \mathrm{mM} \mathrm{NaCl}, 20 \mathrm{mM}$ imidazole, $\mathrm{pH}$ 8.0) and eluted with $2 \mathrm{~mL}$ elution buffer (50 $\mathrm{mM} \mathrm{NaH}_{2} \mathrm{PO}_{4}, 300 \mathrm{mM} \mathrm{NaCl}, 250 \mathrm{mM}$ imidazole, $\mathrm{pH}$ 8.0) an additional elution step of $2 \mathrm{M}$ imidazole was performed to remove all traces of protein from the column. All collected fractions, starting materials, and control supernatants were dried in a centrivap concentrator from $1.5 \mathrm{~mL}$ to a final volume of $400 \mathrm{uL}$ to be used for discontinuous SDS-PAGE (4\% stacking, 9\% separating). Approximately $40 \mathrm{uL}$ of sample was added to $10 \mathrm{uL}$ 10x SDS-PAGE sample buffer and heated before being electrophoresced. After transferring proteins from the gels to a PVDF membrane, western blot analysis was done as previously described with anti-murine FLT3L primary antibody (R\&D Systems). The remaining HIS-FLT3L primary elution was dried completely in the centrivap concentrator and frozen at $-80^{\circ} \mathrm{C}$ until needed. Dried HIS-FLT3L was washed with ethanol and air dried before being resuspended in 1mL sterilized HPLC grade water for use in RAW264.7 cell activity assays. Bradford assays were done on the cell pellet, pellet and 
supernatant from the homoginate, concentrated original supernatant, and concentrated Ni-affinity column fractions as previously described (Bradford, 1976).

\section{Raw 264.7 cell culture and staining}

RAW 264.7 cells were grown in Dulbecco's modified Eagle's medium (DMEM) plus 5\% fetal bovine serum (FBS) in 6 -well plates on $2.5 \mathrm{~cm}$ glass cover slips at $37^{\circ} \mathrm{C}$ to $40 \%$ confluence. Cells were washed $3 \times 5 \mathrm{~min}$ with PBS and fixed in PBS $+4 \%$ para-formaldehyde for $20 \mathrm{mins}$ rocking at room temperature. Fixing was terminated by addition of PBS $+5 \%$ glycine at room temperature for $5 \mathrm{~min}$ and washed once more 3 x $5 \mathrm{~min}$ with PBS. Cell staining was done with Alexa Fluor 488® phalloidin (Invitrogen) using 0.2 units $/ \mathrm{mL}$ for 20-30 min in the dark at room temperature.

\section{Confirmation of FLT3 receptor in RAW264.7 cells}

RAW264.7 cells were grown as previously described then collected before adding PBS containing protease cocktail inhibitor (Sigma Aldrich), 4-(2-Aminoethyl) benzenesulfonyl fluoride hydrochloride and phenylmethylsulfonyl fluoride. The cell solution was then lysed with a French ${ }^{\circledR}$ Press (Thermo Spectronic) before adding 2x SDS sample buffer and being boiled for 10min. Approximately $40 \mathrm{uL}$ of RAW264.7 cell lysates were run on a 9\% SDS-PAGE gel and transferred onto polyvinylidene fluoride (PVDF) membrane wet with $100 \%$ methanol. The PVDF was blocked for 30mins at room temperature with 5\% milk solution in PBST with 1\% goat serum. It was then washed once with TBST and the primary antibody (anti-FLT3 mouse, rabbit polyclonal IgG) was applied (1:1000) for $30 \mathrm{~min}$ room temperature. After three 5 min washes with TBST, the secondary antibody, goat anti-rabbit HRP, was applied $(1: 10,000)$ for 30 min at room temperature then washed 3 x $5 \mathrm{~min}$. The PVDF membrane was developed using ECL Western blot solution (100 mM Tris pH 8.8, 250 mM Luminol, 2 mM IPBA) (Haan \& Iris, 2007). 
The elution fractions of HIS-FLT3L and the Control Supernatant were dried in centrivap concentrator and resuspended in water to a final concentration of $3.294 \mathrm{mg} / \mathrm{mL}$ HIS-FLT3L and $1.6270 \mathrm{mg} / \mathrm{mL}$ Control. Approximately 3.3, 6.6, 13.2, $16.5 \mathrm{ug}$ of HIS-FLT3L, and 11.2, 22.4, 44.8, 56 ug of control yeast supernatant was applied to RAW264.7 cells (grown as previously described) and left at $37^{\circ} \mathrm{C}$ overnight. Final concentration of protein in each $3 \mathrm{~mL}$ well: HISFLT3L; $1.1 \mathrm{ug} / \mathrm{mL}, 2.2 \mathrm{ug} / \mathrm{mL}, 4.4 \mathrm{ug} / \mathrm{mL}, 5.5 \mathrm{ug} / \mathrm{mL}$ and Control; $3.73 \mathrm{ug} / \mathrm{mL}, 7.46 \mathrm{ug} / \mathrm{mL}$, $14.9 \mathrm{ug} / \mathrm{mL}, 18.7 \mathrm{ug} / \mathrm{mL}$. Staining of cells done as previously described and visualized using a LSM 510 META laser scanning microscope. 


\section{RESULTS}

\section{Cloning of HIS-FLT3LpKLAC2 and FLT3LpKLAC2}

A truncated version of FLT3L without the native signal sequence, transmembrane, and cytosolic regions, was amplified by PCR from a full length sequence in order to allow for greater protein solubility when using the K.lactis expression system. Restriction digest of the purified plasmid from E.coli $\mathrm{DH} 10 \mathrm{~B}$ was confirmed to be pDC406 containing full length murine FLT3L insert (Figure 6). As predicted, PCR of the truncated FLT3L and HIS-FLT3L displayed a band at approximately $505 \mathrm{~kb}$ and $535 \mathrm{~kb}$ respectively (Figure 7). The truncated fragments were successfully ligated into pKLAC2 plasmid within the Lac4 yeast promoter (Figure 8, 9). The new constructs were homologously integrated with the $K$. lactis genome and whole cell PCR of 8 strains (4 containing HIS-FLT3LpKLAC2, 4 with FLT3LpKLAC2), was able to amplify a 2.4kb product indicating successful integration of the construct DNA (Figure 10).

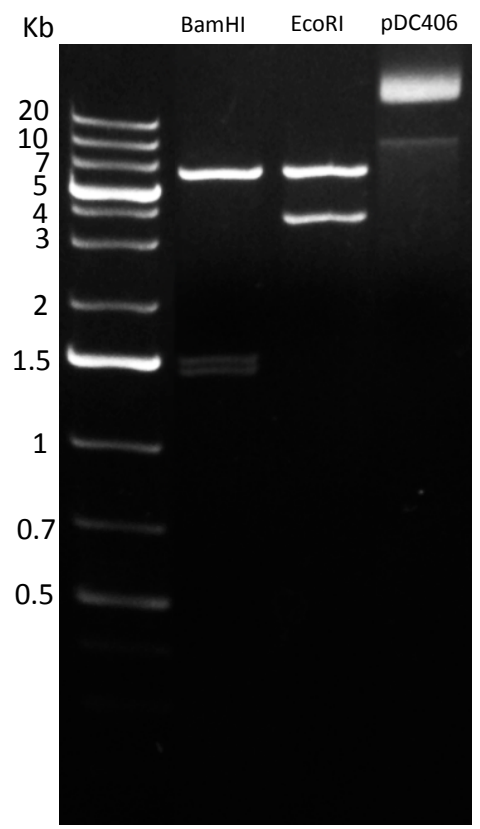

Figure 6. Purified pDC406 cut with BamHI and EcoRI on a 1\% agarose gel. Restriction digests of the clone give the following sizes $(\mathrm{kb})$ : BamHI--7.5, 1.1, 1.1; EcoRI--6.4, 3.4; HindIII--6.4, 1.9, 1.1,0.5; PstI--6.0, 3.7; SalI--9.2, 0.5. 

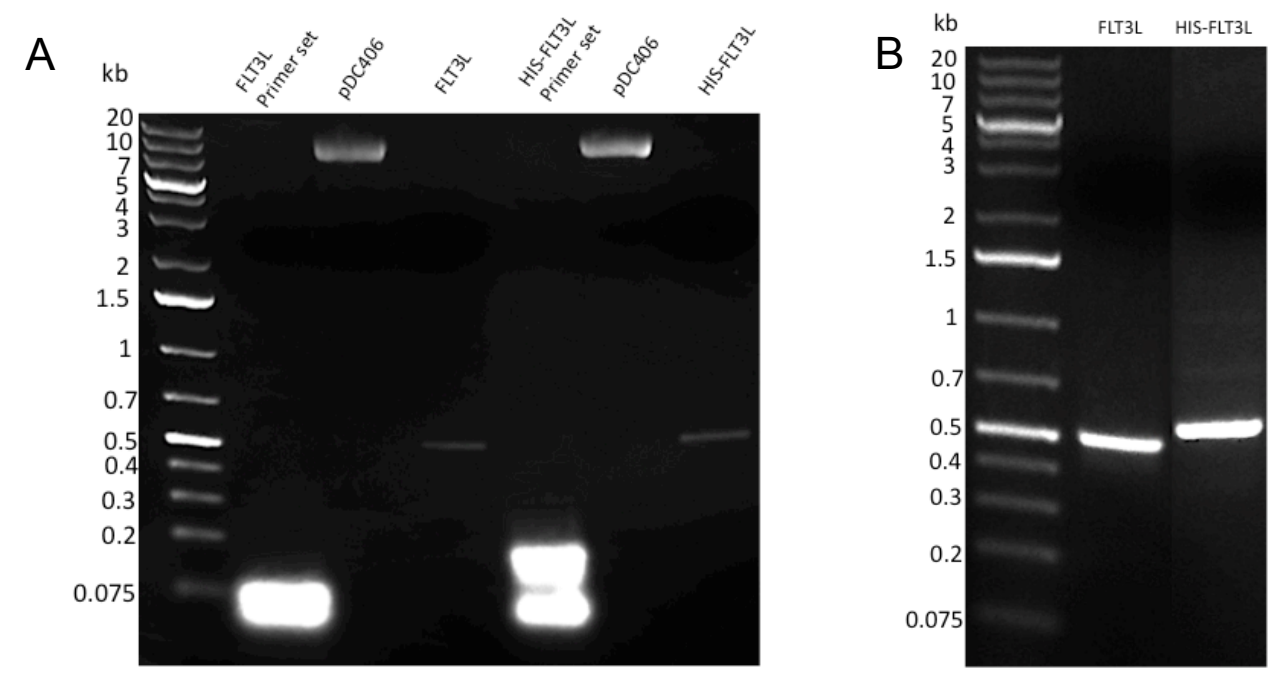

Figure 7. PCR of FLT3L. (A) 1\% agarose gel displaying the PCR template (pDC406) for amplification of FLT3L cDNA, primers used for PCR of HIS-FLT3L, FLT3L, and the respective amplified products (HIS-FLT3L \& FLT3L). (B) $1 \%$ agarose gel displaying amplified PCR products (HIS-FLT3L \& FLT3L) from pDC406 (ATCC).
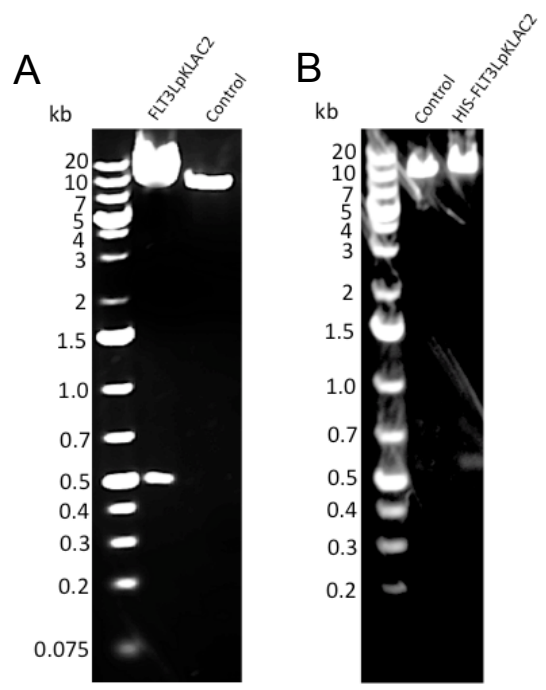

Figure 8. Restriction digests of positive ligations of FLT3L and pKLAC2. 1\% agarose gel displaying positive ligations of FLT3L insert into pKLAC2 along side controls containing no insert. FLT3LpKLAC2 and HIS-FLT3LpKLAC2 sequences confirmed by sequence analysis done at MaRS (Toronto,ON). 


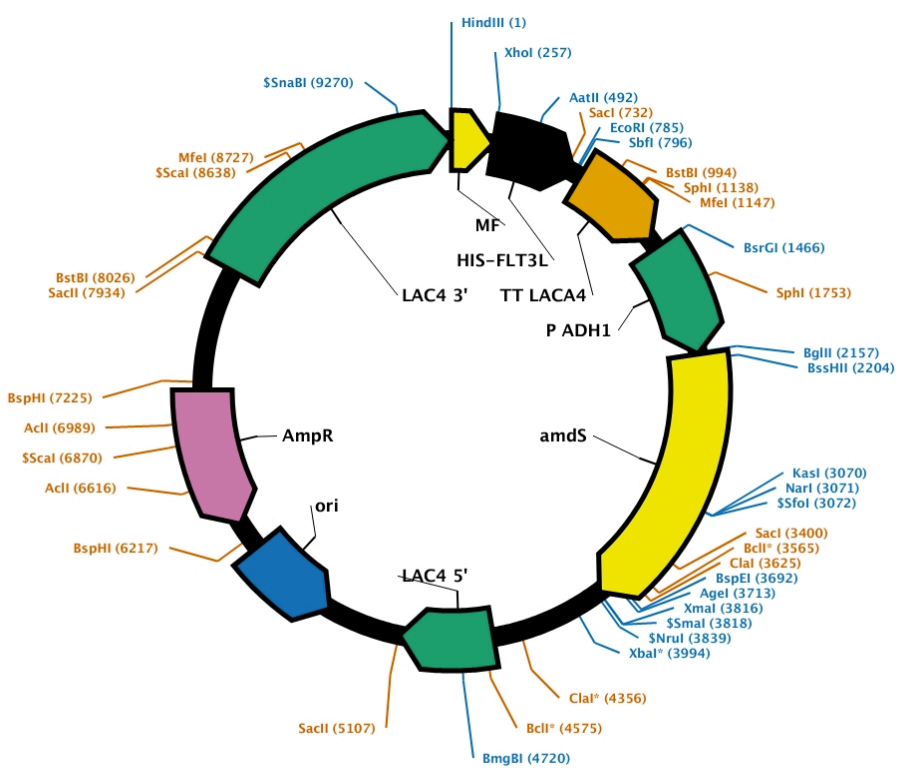

\section{HIS-FLT3LpKLAC2 \\ $9563 \mathrm{bp}$}

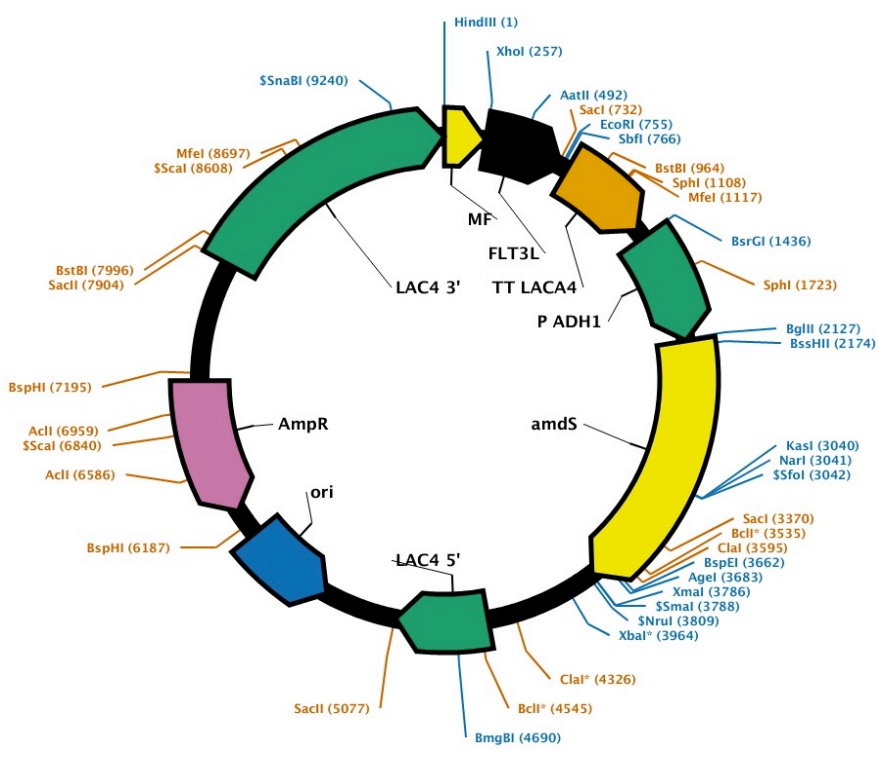

FLT3LPKLAC2

9533 bp

Figure 9. HIS-FLT3LpKLAC2 and FLT3LpKLAC2 plasmid maps. Contains the 3' and 5' ends of the LAC4 promoter from K.lactis for homologous integration, (LAC4 3'/LAC4 5') ampicillin resistant (AmpR) and acetemide gene (amdS) for bacteria and yeast selection, $\alpha$-mating factor (MF) secretion domain, multiple cloning site (MCS), Adh1 (P ADH1) promoter that drives the expression of the amdS gene. 


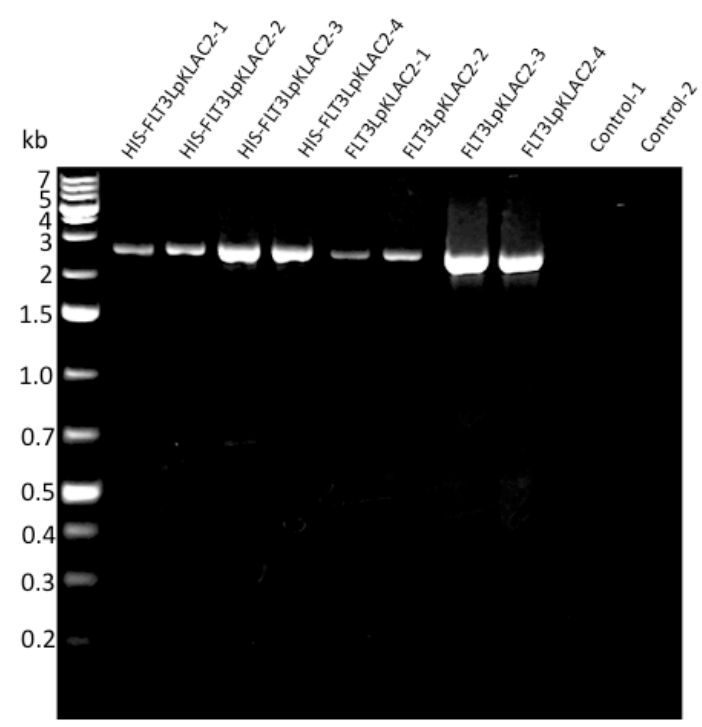

Figure $10.1 \%$ agarose gel displaying strains of $K$. lactis with integrated HIS-FLT3LpKLAC2 or FLT3LpKLAC2 DNA alongside controls where DNA had not integrated. Whole cell PCR of positive strains yield a $2.4 \mathrm{~kb}$ product using integration primers 1 and 2 (New England Biolabs) designed to target the insert site within the LAC4 yeast promoter. 
The Western dot-blot determined that strain all positive strains of $K$. lactis were expressing HIS-FLT3L or FLT3L (Figure 11). Dialysis of the yeast supernatant brought the $\mathrm{pH}$ from 4.67 to $7.5-8$. The Ni-affinity chromatography fractions of HIS-FLT3L were analyzed with SDS-PAGE, Western blot and mass spectrometry to determine the presence of FLT3L. The coommassie stained 9\% SDS-PAGE gels consistently showed a band around $50 \mathrm{kDa}$ that was not clearly seen in the crude supernatant fractions (Figures 12, 14 \& 16). Additionally, the elution fraction showed two other bands at $250 \mathrm{kDa}$ and $75 \mathrm{kDa}$ (Figures 12, $14 \& 16$ ). Western blot analysis showed no reaction with the wash fraction, but a dark smear consistently appeared in the elution fraction (Figures 13, $15 \& 17$ ). Total concentration of protein in a $2 \mathrm{~mL}$ elution volume ( $150 \mathrm{~mL}$ dialysed supernatant starting volume) was $0.1 \mathrm{mg} / \mathrm{mL}$ as determined by Bradford assay (Table 3). Mass spectrometry analysis showed that the 250,75 and $50 \mathrm{kDa}$ bands in the elution corresponded to FLT3L, however the $50 \mathrm{kDa}$ band seen in the wash did not contain FLT3L (Figure 14, 18-21, Table 4).

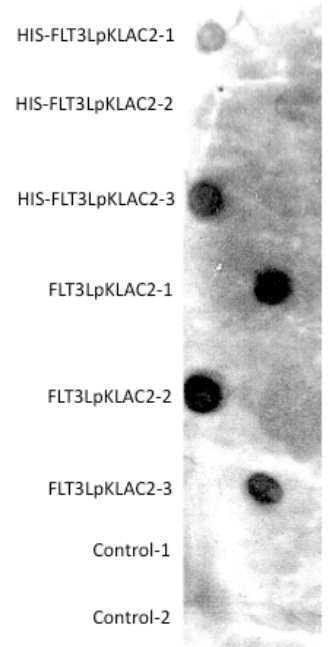

Figure 11. Western dot-blot of K.lactis crude supernatant. Crude supernatant from 3 different HIS-FLT3LpKLAC2 strains, FLT3LpKLAC2 strains, and 2 control strains of $K$. lactis were spotted on PVDF ( $2 \mu \mathrm{L}$ crude supernatant from $50 \mathrm{~mL}$ total culture) and a Western was performed using an anti-FLT3L murine monoclonal antibody (R\&D systems). 


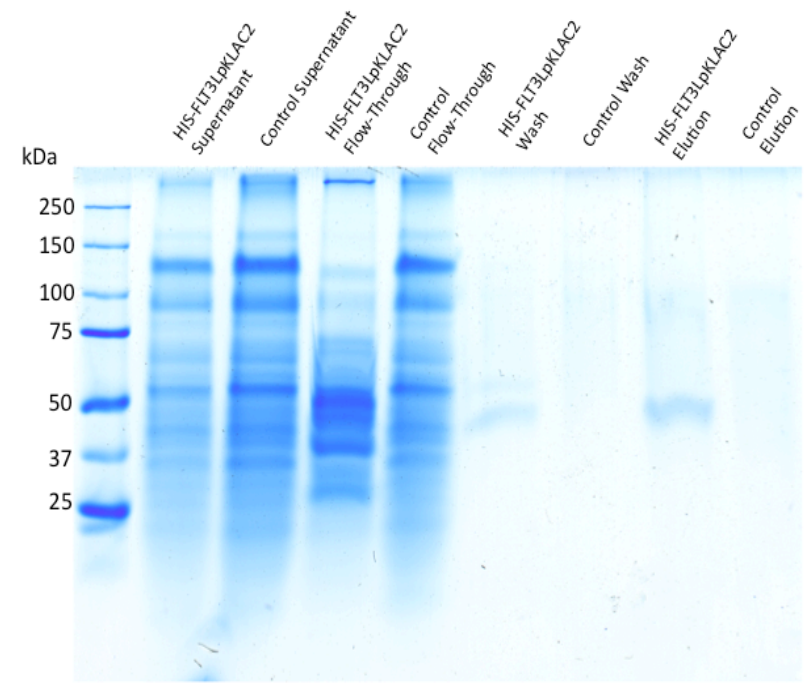

Figure 12. Coomassie stained $9 \%$ SDS-PAGE of HIS-FLT3LpKLAC2 and Control fractions after Ni-affinity chromatography. Supernatant $(150 \mathrm{~mL})$ was collected and dialyzed against 10 $\mathrm{mM}$ phosphate buffer $(\mathrm{pH} 8)$ to a final $\mathrm{pH}$ of 7.1 and subjected to a $1 \mathrm{~mL} \mathrm{Ni-column}$. Column was washed with $10 \mathrm{mM}$ phosphate buffer containing $20 \mathrm{mM}$ imidazole and eluted with $10 \mathrm{mM}$ phosphate buffer containing $250 \mathrm{mM}$ imidazole.

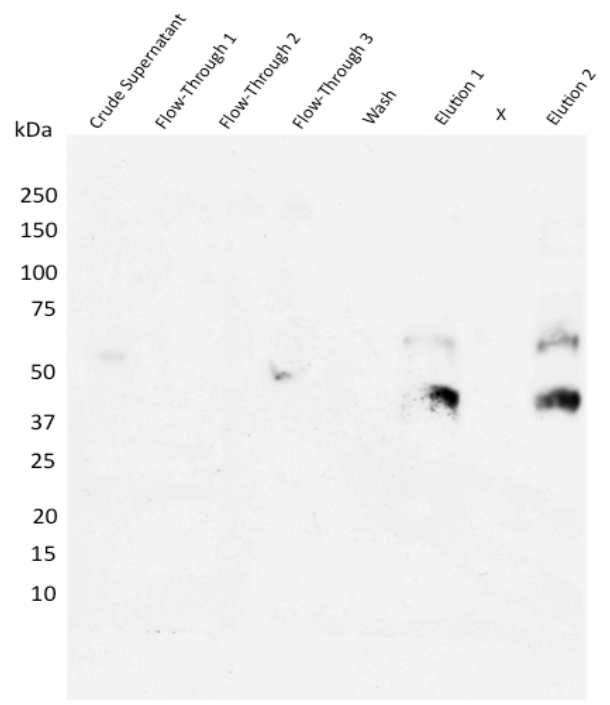

Figure 13. Western blot of Ni- affinity chromatography fractions of HIS-FLT3LpKLAC2. Supernatant $(150 \mathrm{~mL})$ was collected and dialyzed against $10 \mathrm{mM}$ phosphate buffer $(\mathrm{pH} 8)$ to a final $\mathrm{pH}$ of 7.7 and subjected to a $1.5 \mathrm{~mL}$ Ni-column. Column was washed with $10 \mathrm{mM}$ phosphate buffer containing $20 \mathrm{mM}$ imidazole and eluted with $10 \mathrm{mM}$ phosphate buffer containing $250 \mathrm{mM}$ imidazole. Western was performed using an anti-FLT3L murine monoclonal antibody ( $\&$ D systems). 


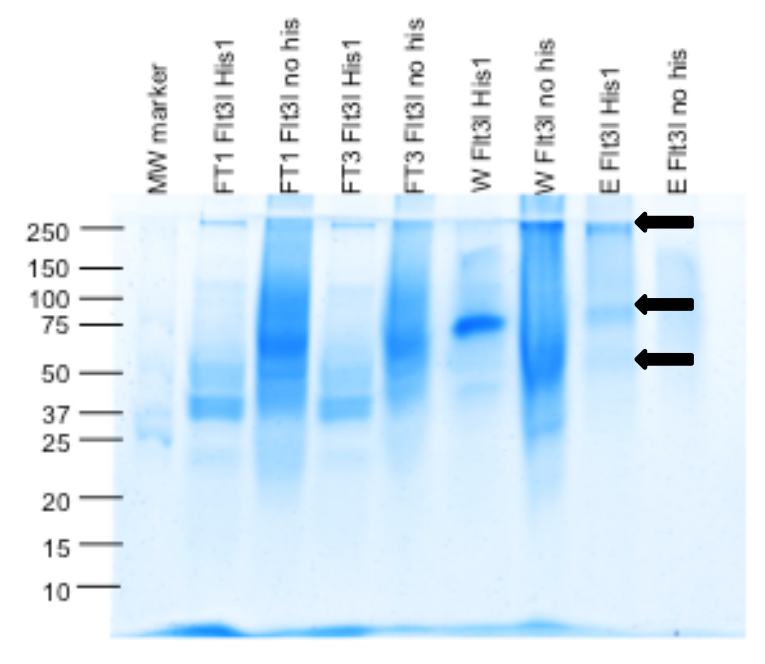

Figure 14. Coomassie stained $9 \%$ SDS-PAGE of HIS-FLT3LpKLAC2 and FLT3LpKLAC2 fractions after Ni-affinity chromatography. Supernatant $(150 \mathrm{~mL})$ was collected and dialyzed against $10 \mathrm{mM}$ phosphate buffer $(\mathrm{pH} 8)$ to a final $\mathrm{pH}$ of 7.7 and subjected to a $1 \mathrm{~mL}$ Ni-column. Column was washed with $10 \mathrm{mM}$ phosphate buffer containing $20 \mathrm{mM}$ imidazole and eluted with $10 \mathrm{mM}$ phosphate buffer containing $250 \mathrm{mM}$ imidazole. Arrows indicate where bands were cut for digestion and MS analysis.

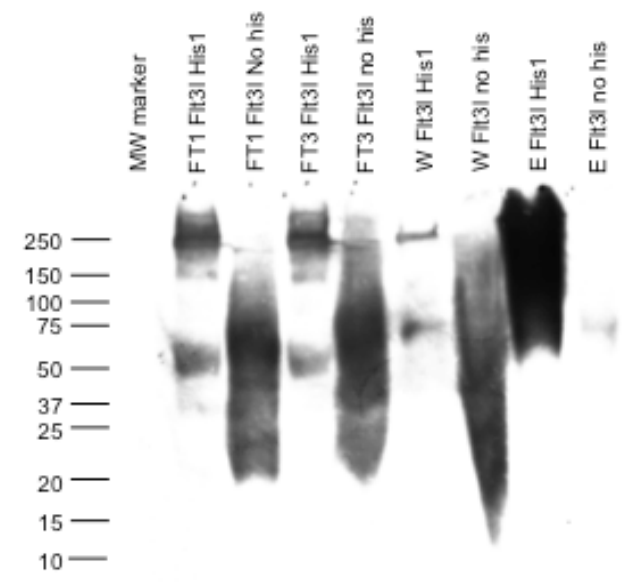

Figure 15. Western blot of HIS-FLT3LpKLAC2 and FLT3LpKLAC2 fractions after Ni-affinity chromatography. Supernatants $(150 \mathrm{~mL})$ were collected and dialyzed against $10 \mathrm{mM}$ phosphate buffer ( $\mathrm{pH} 8$ ) to a final $\mathrm{pH}$ of 7.7 and subjected to a $1.5 \mathrm{~mL} \mathrm{Ni-column}$. Column was washed with $10 \mathrm{mM}$ phosphate buffer containing $20 \mathrm{mM}$ imidazole and eluted with $10 \mathrm{mM}$ phosphate buffer containing $250 \mathrm{mM}$ imidazole. Western was performed using an anti-FLT3L murine monoclonal antibody (R\&D systems). 


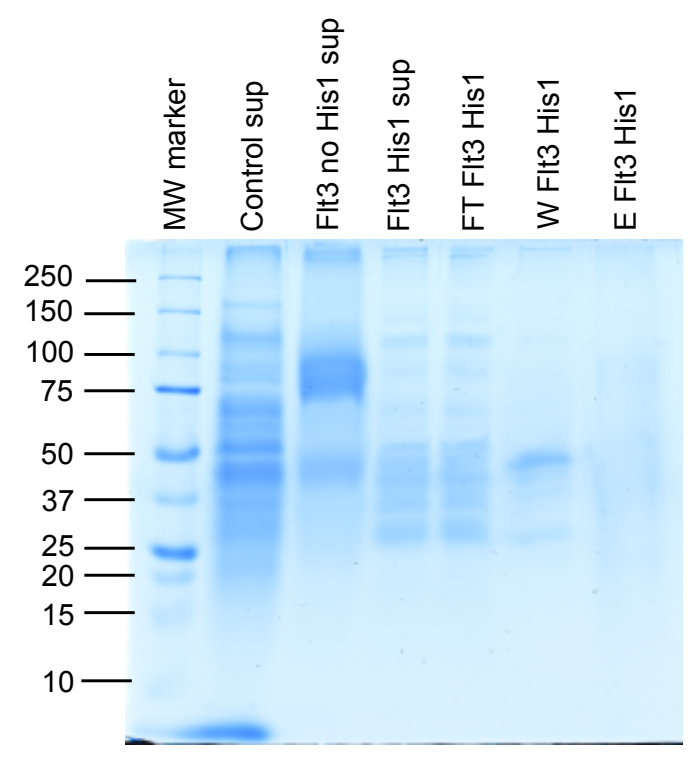

Figure 16. 9\% Coomassie stained SDS-PAGE of Control, FLT3LpKLAC2, and HISFLT3LpKLAC2 supernatant and all other HIS-FLT3LpKLAC2 fractions after Ni-affinity chromatography. Supernatant $(150 \mathrm{~mL})$ were collected and dialyzed against $10 \mathrm{mM}$ phosphate buffer $(\mathrm{pH} 8)$ to a final $\mathrm{pH}$ of 7.1 and subjected to a $1 \mathrm{~mL} \mathrm{Ni-column.} \mathrm{Column} \mathrm{was} \mathrm{washed} \mathrm{with}$ $10 \mathrm{mM}$ phosphate buffer containing $20 \mathrm{mM}$ imidazole and eluted with $10 \mathrm{mM}$ phosphate buffer containing $250 \mathrm{mM}$ imidazole.

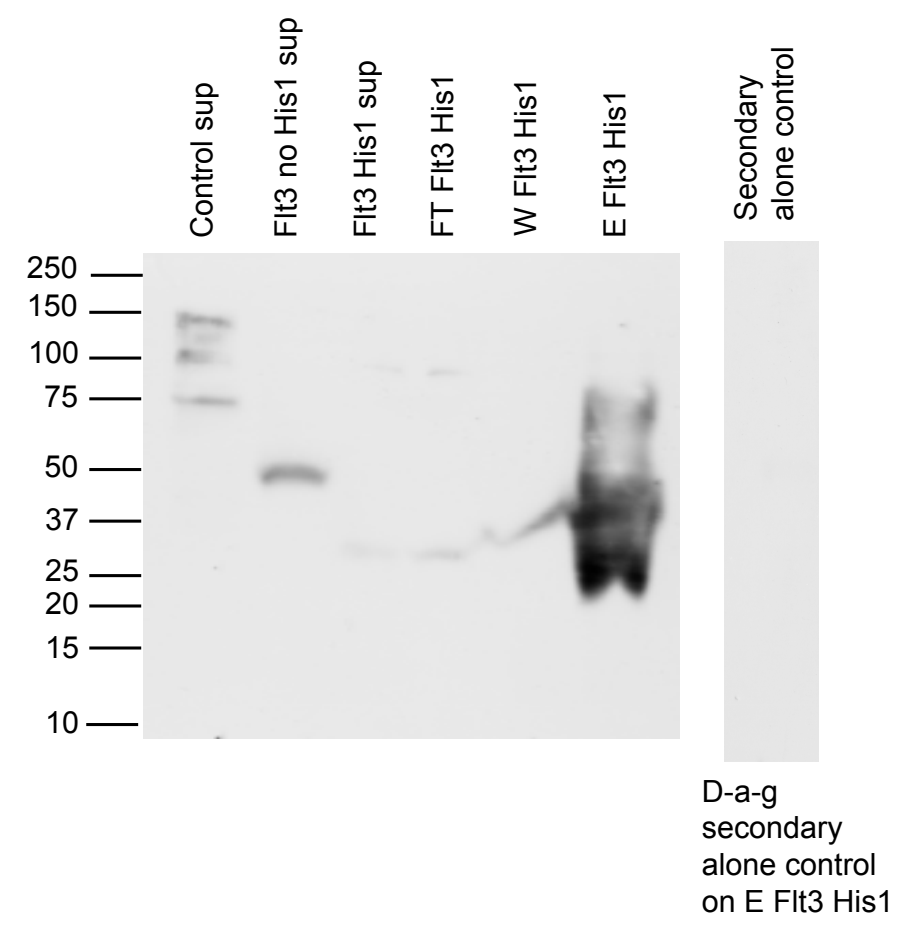

Figure 17. Western blot of Control, FLT3LpKLAC2, and HIS-FLT3LpKLAC2 supernatant and all other HIS-FLT3LpKLAC2 fractions after Ni-affinity chromatography. Supernatants $(150 \mathrm{~mL})$ were collected and dialyzed against $10 \mathrm{mM}$ phosphate buffer $(\mathrm{pH} 8)$ to a final $\mathrm{pH}$ of 7.7 and subjected to a $1.5 \mathrm{~mL} \mathrm{Ni}$-column. Column was washed with $10 \mathrm{mM}$ phosphate buffer containing $20 \mathrm{mM}$ imidazole and eluted with $10 \mathrm{mM}$ phosphate buffer containing $250 \mathrm{mM}$ imidazole. Western was performed using an anti-FLT3L murine monoclonal antibody (R\&D systems). 
Table 3. Bradford assay on HIS-FLT3LpKLAC fractions after Ni-affinity chromotography.

\begin{tabular}{|l|c|c|}
\hline Fraction & Concentration $(\mathbf{m g} / \mathbf{m L})$ & Total mg protein in sample \\
\hline Supernatant $(150 \mathrm{~mL})$ & 1.0 & 150 \\
\hline FT $(150 \mathrm{~mL})$ & $0.5-0.75$ & $75-112.5$ \\
\hline Wash $(8 \mathrm{~mL})$ & 0.05 & 0.4 \\
\hline Elution $(2 \mathrm{~mL})$ & 0.1 & 0.2 \\
\hline Beads & $0-0.01$ & $\sim 0$ \\
\hline
\end{tabular}

* Stating material was $150 \mathrm{~mL}$, flowthrough $150 \mathrm{~mL}$, wash $8 \mathrm{~mL}$, Elution $2 \mathrm{~mL}$, second elution ( $2 \mathrm{M}$ imidazole) $2 \mathrm{~mL}$, and boiled beads in SDS. Total protein eluted from a $150 \mathrm{~mL}$ culture is $200 \mu \mathrm{g}$.

Table 4. Mass Spectrometry hits of 9\% tricine SDS PAGE cut gel bands (E250, 75, 50kDa).

\begin{tabular}{|c|c|c|c|c|c|c|}
\hline Band & Accession \# & Coverage & \# Peptides & \#AAs & Score & Protein \\
\hline $250 \mathrm{kDa}$ & gi31982428 & 6.90 & 5 & 232 & 8.35 & \multirow{6}{*}{$\begin{array}{l}\text { FLT3L } \\
\text { (mouse) }\end{array}$} \\
\hline \multirow{5}{*}{$\begin{array}{l}\text { Identified } \\
\text { Peptides }\end{array}$} & \multicolumn{4}{|c|}{ ALWSLFLAQR } & 32.13 & \\
\hline & \multicolumn{4}{|c|}{ ALWSLFLAQR } & 14.98 & \\
\hline & \multicolumn{4}{|c|}{ WIEQLK } & 1.00 & \\
\hline & \multicolumn{4}{|l|}{ WIEQLK } & 2.00 & \\
\hline & \multicolumn{4}{|l|}{ WIEQLK } & 1.00 & \\
\hline 75 kDa & gi31982428 & 9.05 & 3 & 232 & 6.58 & \multirow{4}{*}{$\begin{array}{l}\text { FLT3L } \\
\text { (mouse) }\end{array}$} \\
\hline \multirow{3}{*}{$\begin{array}{l}\text { Identified } \\
\text { Peptides }\end{array}$} & \multicolumn{4}{|c|}{ ALWSLFLAQR } & 26.91 & \\
\hline & \multicolumn{4}{|c|}{ ALWSLFLAQR } & 26.26 & \\
\hline & \multicolumn{4}{|c|}{ FVQTNISHLLK } & 2.25 & \\
\hline 50 kDa & gi31982428 & 14.66 & 3 & 232 & 7.00 & \multirow{4}{*}{$\begin{array}{l}\text { FLT3L } \\
\text { (mouse) }\end{array}$} \\
\hline \multirow{3}{*}{$\begin{array}{l}\text { Identified } \\
\text { Peptides }\end{array}$} & \multicolumn{4}{|c|}{ ALWSLFLAQR } & 27.65 & \\
\hline & \multicolumn{4}{|c|}{ ALWSLFLAQR } & 26.37 & \\
\hline & \multicolumn{4}{|c|}{ FRELTDHLLKDYPVTVAVNLQDEK } & 1.00 & \\
\hline
\end{tabular}

* Digested with acetic acid/trypsin/formic acid solution and subjected to mass spectrometry. Elution band fraction (HIS1) of figure 17 at 250, 75 and $50 \mathrm{kDa}$. Bands cut from figure 14. Note that the peptides identified are characteristic of those cut by trypsin. 


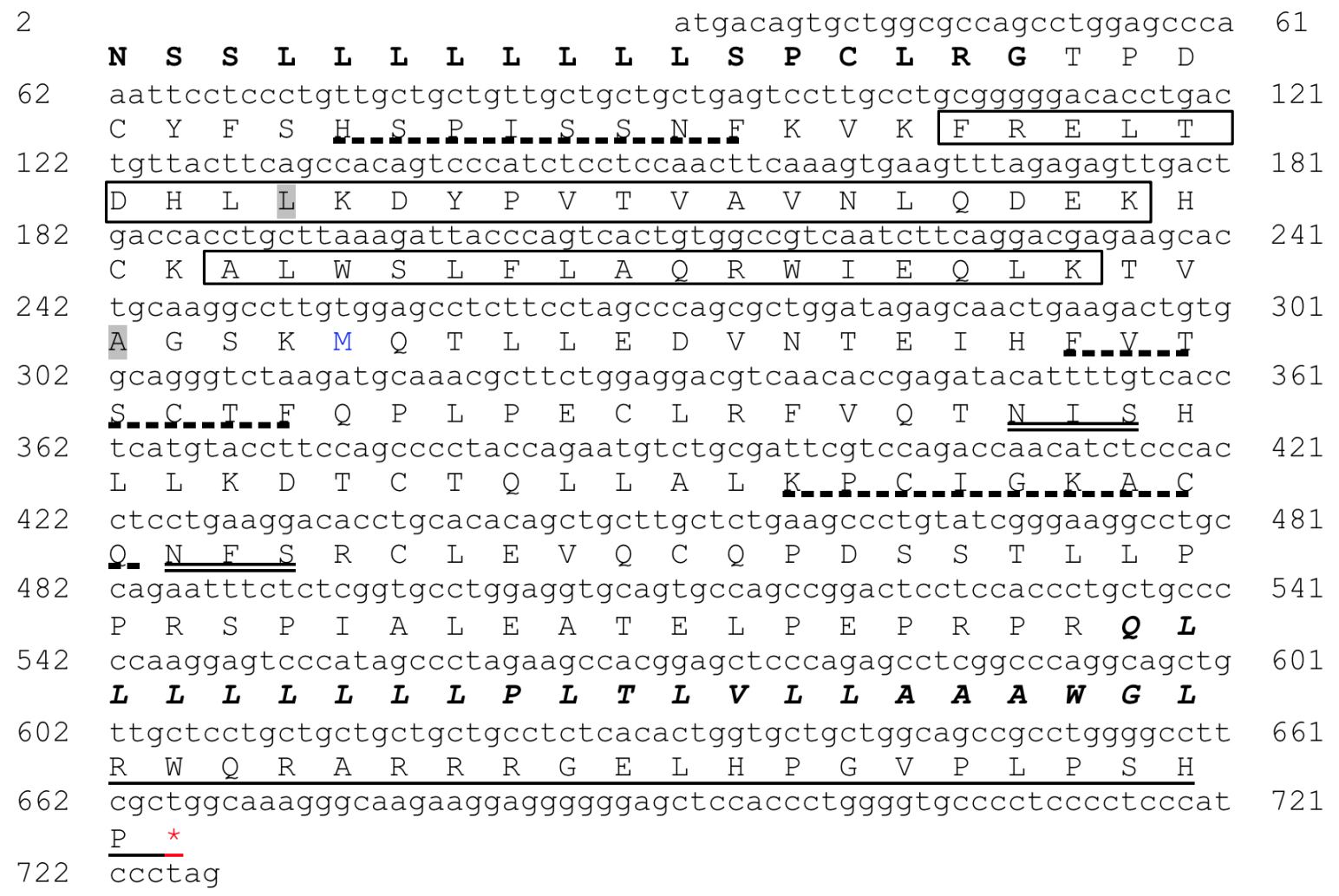

Figure 18. Full nucleotide and amino acid sequence of murine FLT3L. Signal sequence in bold (27 aa), N-linked glycosylation sites are double underlined, cytosolic region single underlined (21aa), transmembrane region in bold/italics (22 aa), FLT3L receptor binding domains are represented by a broken underline, grey highlighted area are amino acids at the dimerization surface. Boxed areas are those sequences identified by mass spectrometry (Table 4, pg 43). 

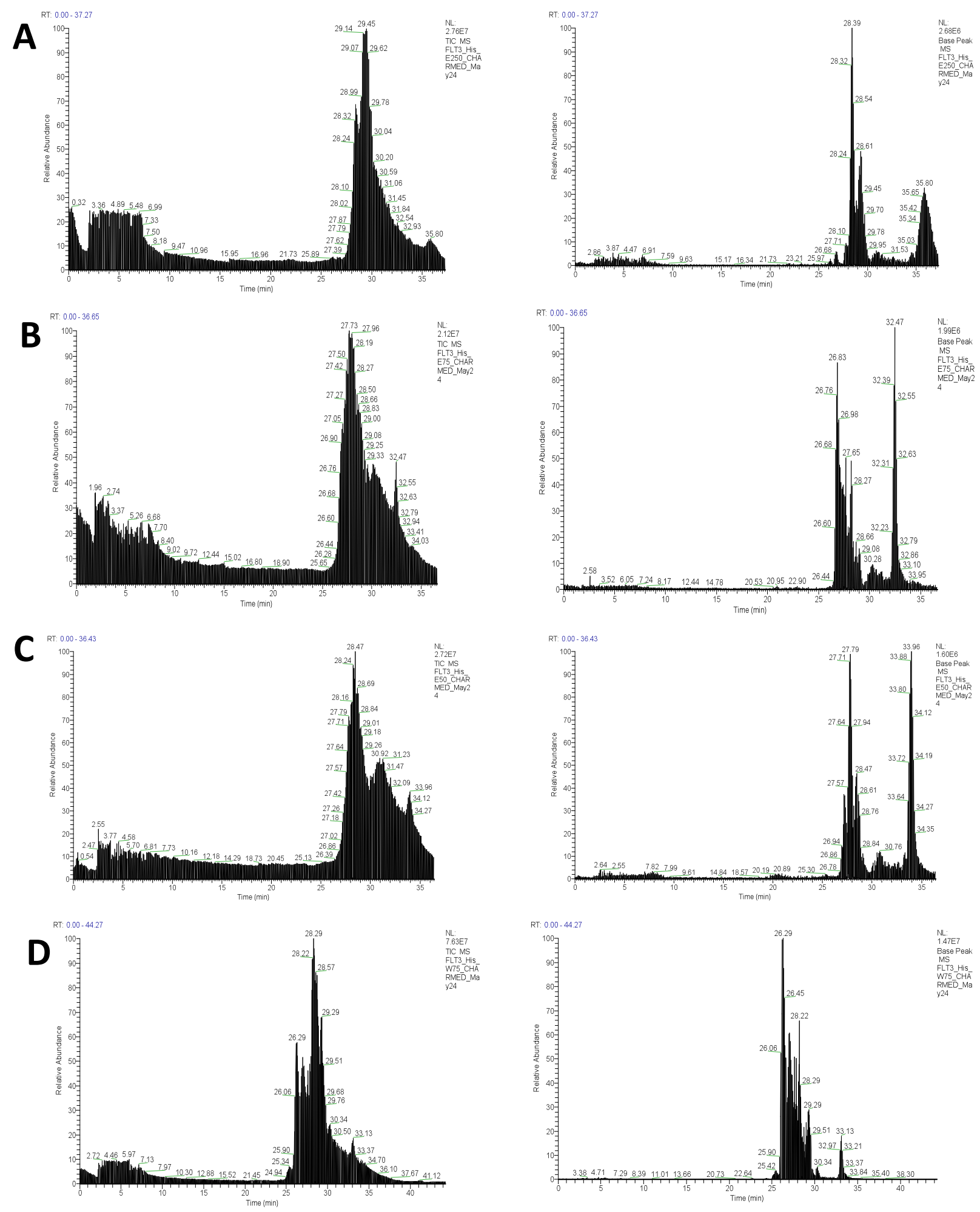

Figure 19. Mass spectrometry TIC and Base Peaks, respectively for elution gel bands cut from figure 17 at (A) $250 \mathrm{kDa},(\mathrm{B}) 75 \mathrm{kDa},(\mathrm{C}) 50 \mathrm{kDa}$, and the wash band cut at $50 \mathrm{kDa}$ (D). 

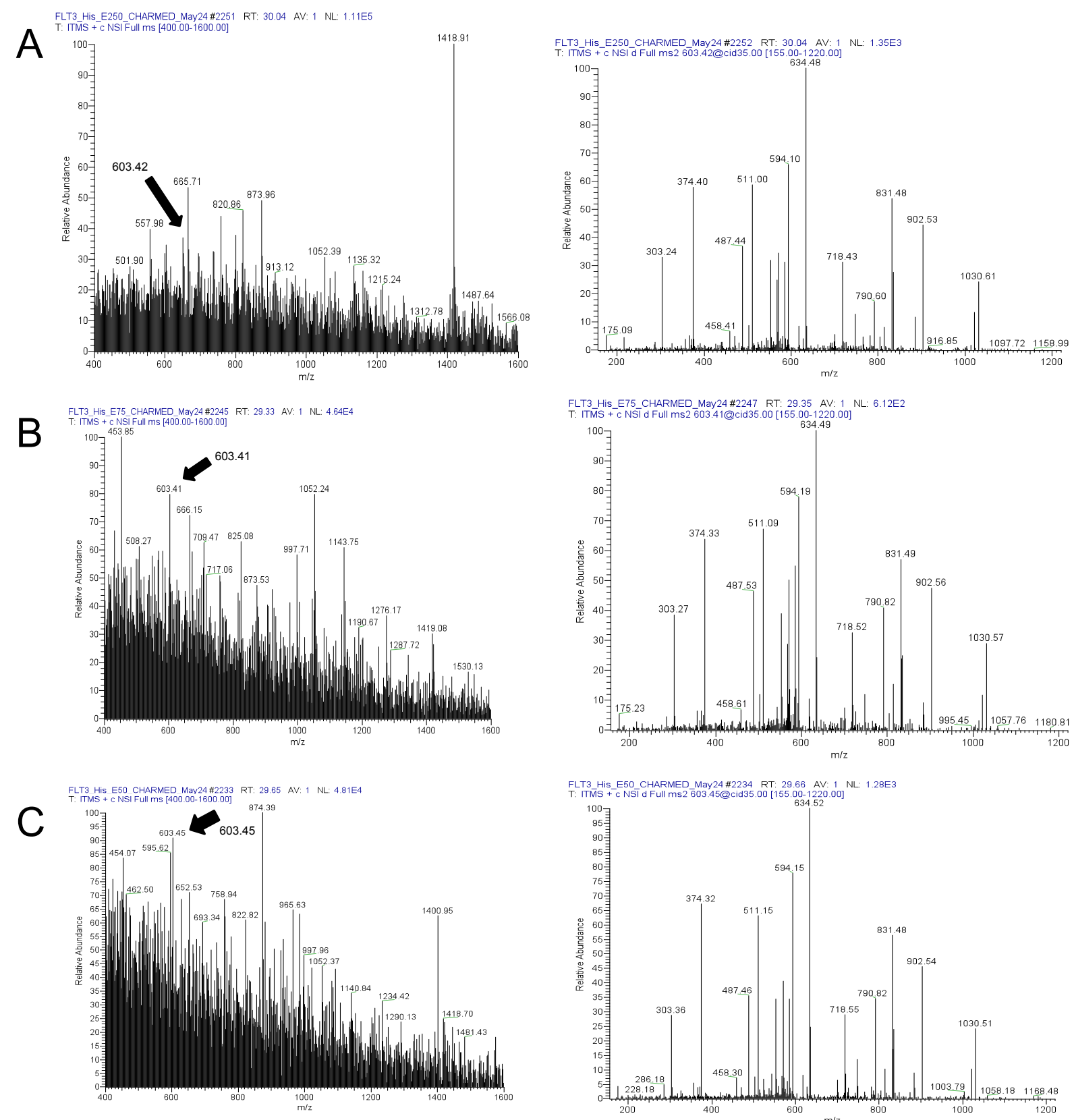

Figure 20. MS and MS/MS data respectively, from FLT3L found in elution gel bands cut from figure 17 (A) $250 \mathrm{kDa}$, (B) $75 \mathrm{kDa}$ and (C) $50 \mathrm{kDa}$. 

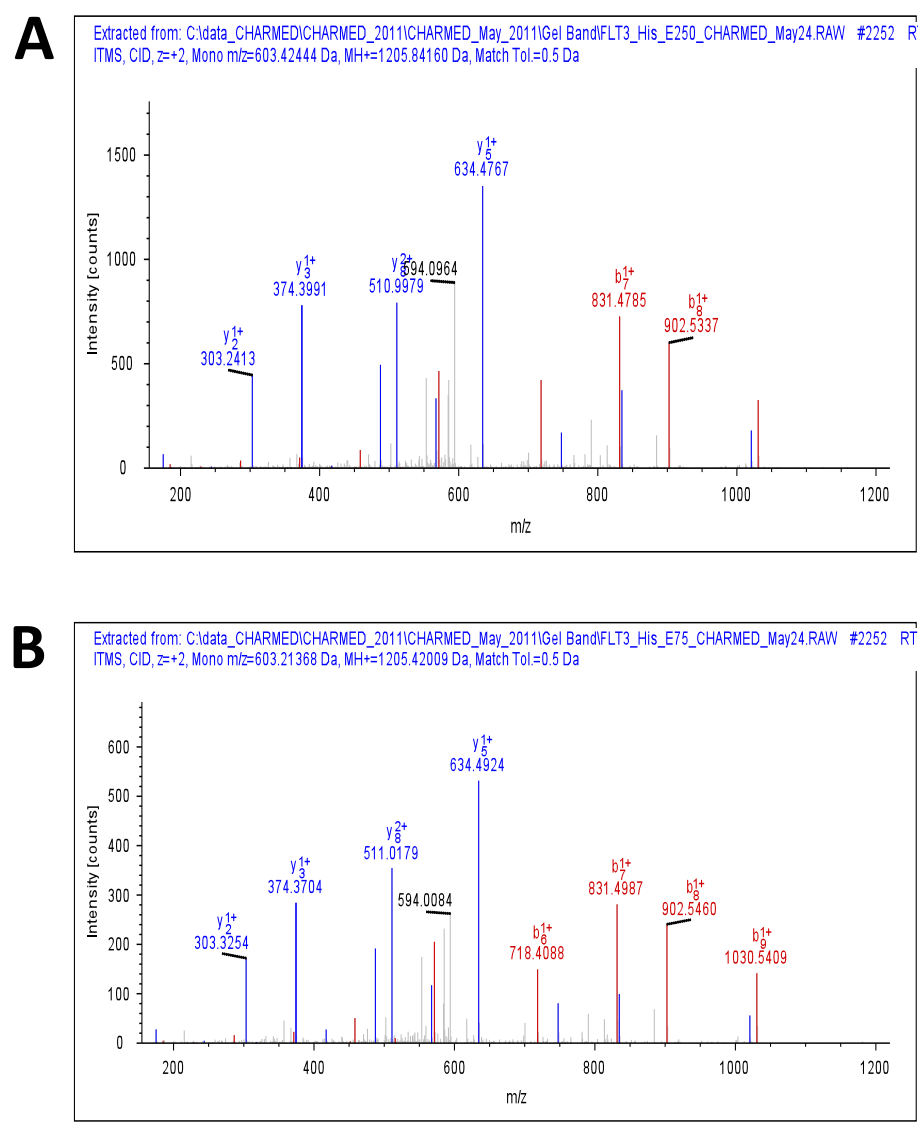

C Extracted from: Cildata_CHARMEDICHARMED_2011ICHARMED_May_20111Gel BandIFLT3_His_E50_CHARMED_May24.RAW \#2234 RT

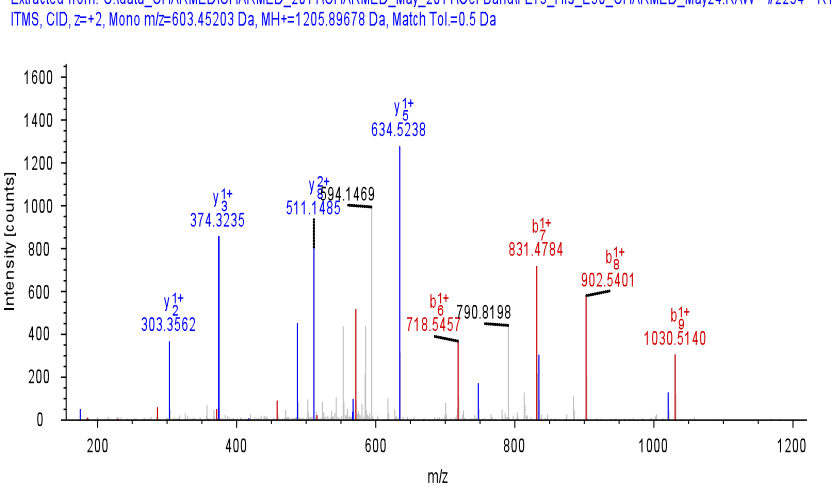

Figure 21. Mass spectrum of FLT3L originating from bands cut from figure 17 at (A) $250 \mathrm{kDa}$, (B) $75 \mathrm{kDa},(\mathrm{C}) 50 \mathrm{kDa}$. 
A Western blot analysis of RAW254.7 cell lysates was done to determine if the RAW cells expressed the FLT3 receptor. The blot showed two bands around 125 and $145 \mathrm{kDa}$ (Figure 22) which is consistent with previous western blot analysis of murine FLT3. All RAW264.7 cells exposed to HIS-FLT3L (3.3, 6.6, 13.2, or 16.5ug) (final concentrations of $1.1 \mathrm{ug} / \mathrm{mL}, 2.2$ $\mathrm{ug} / \mathrm{mL}, 4.4 \mathrm{ug} / \mathrm{mL}$ or $5.5 \mathrm{ug} / \mathrm{mL}$ ) had increased vacuole size and were more spread out compared to the controls (Figure 23).

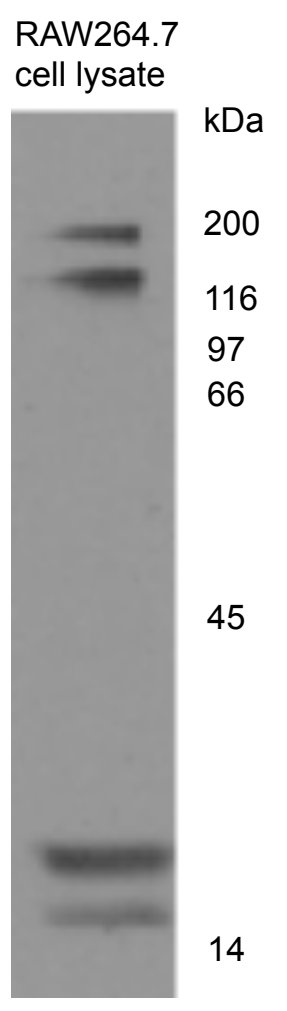

Figure 22. Western blot of RAW264.7 cell lysate with anti-FLT3 mouse, rabbit IgG. Bands are consistent with the size of FLT3 at around 120-145 kDa. 

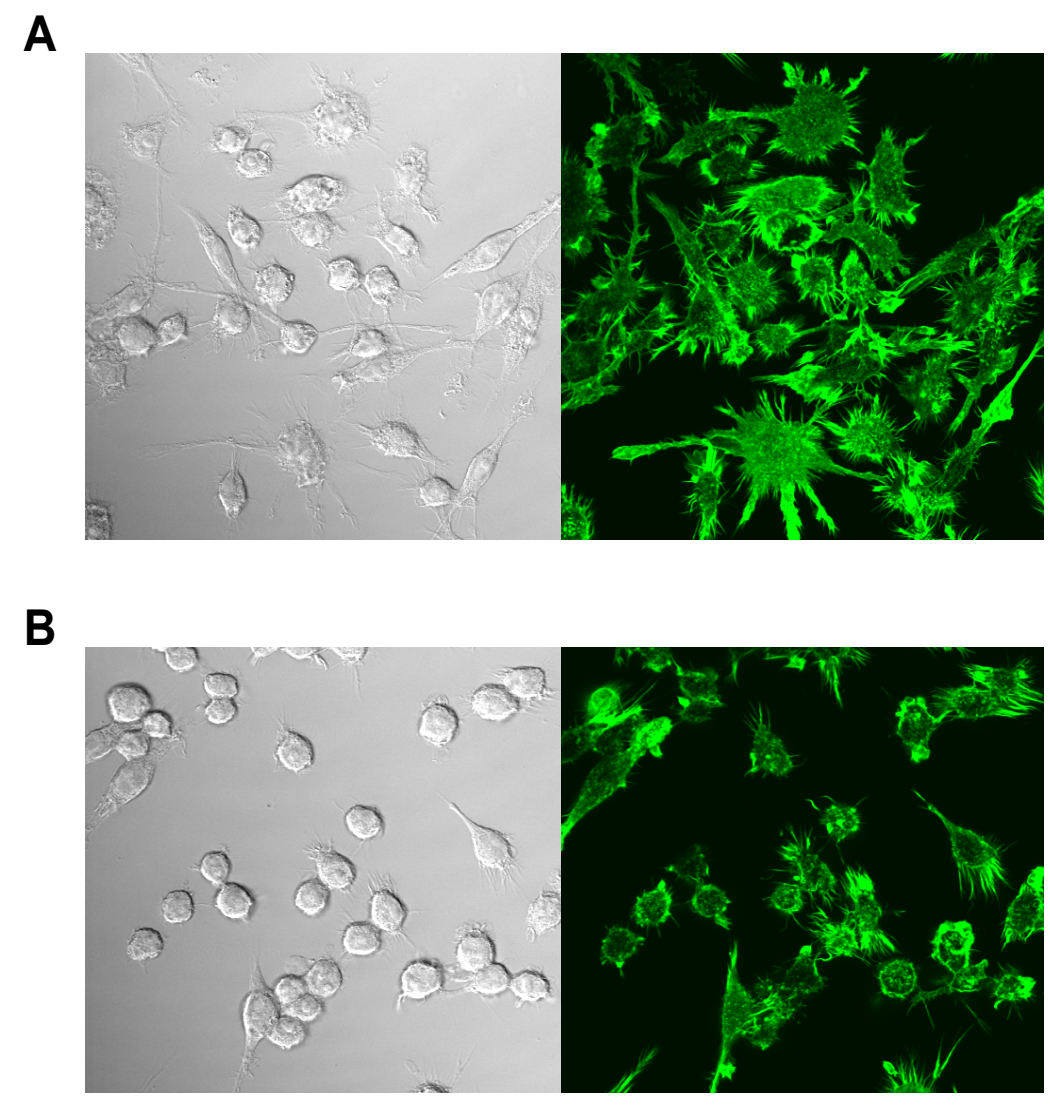

Figure 23. Images of RAW264.7 cells exposed to 3.3, 6.6, 13.2, or 16.5 ug of HIS-FLT3L or $11.2,22.4,44.8,56$ ug of control yeast supernatant for $\sim 24 \mathrm{hrs}$ at $37^{\circ} \mathrm{C}$ (A), FLT3L ligand (B) control. Vacuolated appearance of RAW cells indicates activation according to previous studies. Activation was seen with all concentrations of FLT3L. Shown is the results of 3.3 ug HISFLT3L and $11.2 \mathrm{ug}$ control. Final concentrations of HIS-FLT3L: $1.1 \mathrm{ug} / \mathrm{mL}, 2.2 \mathrm{ug} / \mathrm{mL}, 4.4$ $\mathrm{ug} / \mathrm{mL}, 5.5 \mathrm{ug} / \mathrm{mL}$ and control: $3.73 \mathrm{ug} / \mathrm{mL}, 7.46 \mathrm{ug} / \mathrm{mL}, 14.9 \mathrm{ug} / \mathrm{mL}, 18.7 \mathrm{ug} / \mathrm{mL}$. 


\section{DISCUSSION}

Cloning of FLT3L as well as the integration of HIS-FLT3LpKLAC2 and FLT3LpKLAC2 plasmids into K. lactis was successful. The first construct consisted of the pKLAC2 plasmid with FLT3L cDNA inserted just after a XhoI and Kex region, ending with a EcoRI site (Figure 9). The HIS-FLT3L cDNA was similarly ligated into pKLAC2, but with a 10x HIS tag at the C-terminus before the EcoRI site (Figure 9). Single copy homologous integration of the linearized expression cassette into the $K$. lactis genome displayed a $2.4 \mathrm{~kb}$ product after being subjected to whole cell PCR with primers designed to target the insert site within the LAC4 yeast promoter (Figure 10). Expression of HIS-FLT3L and secretion of the protein into the yeast medium was accomplished over three days of incubation at $30^{\circ} \mathrm{C}$ in $\mathrm{YPGal}$ medium containing $5 \mathrm{mM}$ acetamide. The acetamide gene (amdS) found in the pKLAC2 plasmid allows for the selection of yeast with an integrated expression cassette by permitting growth in nitrogen-free media (New England Biolabs, 2011). Only cells containing amdS are able to break down acetamide to ammonia to use as a nitrogen source (New England Biolabs, 2011). An advantage of this selection method, is that cells which contain multiple copies of the expression cassette are able to better utilize acetamide, thereby growing faster than those with only singlecopy integrants, ultimately resulting in greater protein secretion (New England Biolabs, 2011). Finally, a dot-blot was done with anti-murine FLT3L antibody (R\&D Systems) to ensure that each strain was expressing detectable amounts of FLT3L or HIS-FLT3L (Figure 14).

\section{Purification of HIS-FLT3L}

Since the $\mathrm{pH}$ of the medium was determined to be around 4-5, it was deemed necessary to dialyse the supernatant containing HIS-FLT3L against the binding buffer in order to bring the $\mathrm{pH}$ to a suitable 7-8 and optimize binding conditions of the HIS-tag to the Ni-NTA column (Cox $\&$ Nelson, 2008). Previous trials of Ni-affinity purification with $\mathrm{pH} 4-5$ supernatant did not result in much protein binding to the column and the elution yield of purified protein was very low compared to purification steps done at $\mathrm{pH}$ 7-8. The crude supernatant contained very small amounts of total protein $(1 \mathrm{mg} / \mathrm{mL})$ so in order for bands to show on a SDS-PAGE stained with coomassie, all samples were first concentrated before being applied to the gel. However, the 
small amount of protein in the supernatant made purification easier as it decreased the number of available contaminants during Ni-affinity chromatography steps.

There was a band consistently seen on the SDS-PAGE gels at around 50-75 kDa in both the wash and elution chromatography fractions (Figures 12, $14 \& 16$ ). Additionally, the elution fraction showed a smeared band on the western blot analysis of the corresponding SDS-PAGE gels (Figures 13, $15 \& 17)$. The wash band at $75 \mathrm{kDa}$, and several bands from the elution $(250,75$, $50 \mathrm{kDa}$ ) were cut and digested with trypsin for analysis by MS (Figures 14, 18-21, Table 4). All elution bands were found to contain murine FLT3L, however the $75 \mathrm{kDa}$ wash band cut from the SDS-PAGE gel (Figure 14) did not contain any FLT3L, suggesting the band seen on the SDSPAGE wash fraction may be a contaminant that was weakly bound to the column or HIS-FLT3L which was ultimately eluted with the $20 \mathrm{mM}$ imidazole wash buffer. The smeared elution band seen in the western blots along with the MS data showing FLT3L at 250, 75 and $50 \mathrm{kDa}$, may suggest two things. Firstly, FLT3L may be glycosylated to varying degrees adding different weights to the protein making it much higher than expected, as seen with Zhang et al. (2005), adding as much as $13 \mathrm{kDa}$ to the overall molecular weight. Secondly, although the protein was boiled in SDS buffer before being analysed by SDS-PAGE and western blot, the protein may be aggregating and dimerizing thereby affecting the migration of the protein on an SDS-PAGE resulting in a smeared appearance. Total protein in the $2 \mathrm{~mL}$ elution $(150 \mathrm{~mL}$ dialysed starting material) was determined to be $0.2 \mathrm{mg}(0.1 \mathrm{mg} / \mathrm{mL})$ by Bradford assay.

\section{RAW 264.7 Activity Assays}

Elution fractions were pooled together, dried, and kept at $-80^{\circ} \mathrm{C}$ for storage. When needed, purified HIS-FLT3L was resuspended in sterilized water and used for RAW264.7 activity assays. RAW264.7 cell lysates were analysed with a western blot with anti-murine FLT3 antibody (Santa Cruz Biotechnology Inc). Two bands at around 120 and $145 \mathrm{kDa}$ were seen which correspond to the size of FLT3 seen in murine cells (Figure 22).

Cells were exposed to approximately 3.3, 6.6, 13.2, or $16.5 \mathrm{ug}$ of FLT3L for 24 hours at $37^{\circ} \mathrm{C}$. Activity of RAW264.7 cells was seen with all concentrations of FLT3L used. Cells appear to contain large vacuoles, are spread out, and have large protrusions extending from the cells 
(Figure 23a). The controls were drastically different from those cells exposed to FLT3L. Control cells exposed to control yeast supernatant were small in size, had less protrusions, and small vacuoles (Figure 23b). Previous data suggests RAW264.7 cells develop a dendritic appearance

and become flattened, spread out, and have large vacuoles when activated (Haak-Frendscho et al, 1990). This suggests that the RAW264.7 cells that were administered FLT3L became activated within 24 hours of exposure. These activated cells are then able to perform as mature macrophages.

\section{Future implications of results}

This is the first paper to date, where the soluble portion of FLT3L was produced in the $K$. lactis system using a histadine tag for Ni-affinity chromatography purification. The smeared appearance of the elution band on the Western blots has not been seen in previous FLT3L expression papers. This may provide a unique insight as to the degree of glycosylation and other post-translational modifications to FLT3L. It was originally suggested by Zhang et al. (2005) that there may be other post-translational modifications besides the currently described N-linked glycosylation. Similarly, different sizes of FLT3L were seen on SDS-PAGE and Western blot most likely indicating several different isoforms with varying degrees of glycosylation. However, it is highly unusual that the SDS-PAGE combined with MS analysis showed FLT3L with a weight of up to $250 \mathrm{kDa}$, suggesting aggregation or dimerization of the ligand.

Additionally, FLT3L has never been tested on RAW264.7 macrophage cells. We show here that FLT3L is able to change the morphology of RAW264.7 cells, suggesting that it activates this cell type. Moreover, the ability of FLT3L to activate macrophages in such a short period of time has never before been documented. Typically, FLT3L is often added to a cocktail of colony stimulating factors to produce a response in 3-7 days (Lyman et al, 1994b).

Conversely, we have seen FLT3L alone dramatically change the appearance of RAW264.7 cells within 24 hours causing them to activate in a very short period of time. This finding is important because macrophage cells play a huge role in the phagocytosis of cellular debris and pathogens (Haak-Frendscho et al, 1990). Additionally, macrophage cells are able to stimulate lymphocytes and several immune responses such as the elimination of foreign substances like cancer cells and 
microbes (Haak-Frendscho et al, 1990). As noted earlier, the use of FLT3L to stimulate lymphocytes to eliminate tumor cells, was successful in murine models (Saito et al, 2008). It was also previously noted that antigen-presenting dendritic cell development is also promoted by FLT3 activation, which leads to clonal expansion of dendritic cells in bone marrow, spleen, lymph nodes and blood serum (Saunders et al, 1996; Maraskovsky et al, 1996; Morse et al, 2000). These findings suggest FLT3L simulation may boost immune response to tumors, therefore evidence presented here that FLT3L alone is able to stimulate RAW macrophages in a short period of time is an important insight. Since RAW264.7 cells are readily available and commonly used in laboratory research, this may prove useful for further research into the way FLT3L functions on macrophage cells and the use of the ligand for cancer immunotherapy.

Not only is FLT3L a potential cytokine for use in immunotherapy, but it can also be used in LARC experiments to determine if it has any binding partners in blood. As stated previously, LARC is able to determine what binds to FLT3L and the FLT3-FLT3L receptor complex in live cells to give an accurate depiction of what is happening in cells once the receptor is activated (Jankowski et al, 2008). This knowledge could lead to the discovery of new cancer biomarkers and potential sites for inhibition in cancerous cells. Overall, a protocol for a sustainable source of FLT3L was developed so that the purified product can be used for future LARC experiments to find interactors that might serve as therapeutic agents in human body fluids and cell culture models of myeloid leukemia. 


\section{CONCLUSION}

A truncated, soluble form of FLT3L was amplified from the full length sequence by PCR and cloned into a genomic integration and expression vector for $K$. lactis secretion of the 161 amino acid FLT3L then analyzed by SDS-PAGE, Western blot and mass spectrometry. Western blot analysis showed a smeared band in the elution fraction from Ni-NTA affinity chromatography purification. Western blot and LC-ESI MS/MS showed that FLT3L had varying degrees of glycosylation or other posttranslational modifications, which would make the molecular weight higher than expected. Additionally, FLT3L at such high molecular weights has not been seen before in previous literature, however it has been shown that there may be modifications other than N-linked glycosylation, involved in FLT3L production (Zhang et al, 2005). The novel activity assay done in RAW264.7 cells showed that FLT3L was able to activate the macrophages in approximately 24 hours resulting in large vacuoles and a spread out appearance compared to controls. The purified FLT3 ligand will be utilized for LARC proteinprotein interaction studies to search for interactors in blood that may provide insight into potential avenues for drug development for leukemic conditions. 


\section{FUTURE OBJECTIVES}

Future work with the purified FLT3L ligand will include attaching it to microbeads to use in pull-down LARC protein interaction studies to search for interactors that might serve as therapeutic agents in human body fluids and cell culture models of myeloid leukemia. Other future work could also focus on using endoglycosylation $\mathrm{H}$ on the purified FLT3L to determine whether there is a shift in weight from the cleavage of asparagine-linked mannose rich oligosaccharides on the protein. Additional experiments could include RAW264.7 activity assays using a wider range of masses of FLT3L protein to determine what is the minimum concentration that can be used to illicit a response and at which point in time does the dendritic phenotype appear after RAW264.7 cells are exposed to FLT3L. Lastly, a phagocytosis assay could be completed to determine whether the RAW264.7 cells are capable of internalizing microbeads and at what rate the beads are engulfed. 


\section{APPENDIX A - ADDITIONAL FLT3L SEQUENCE INFORMATION}

\section{Extracellular portion of mouse FLT3L}

62

T P D

acacctgac

121

122 tgttacttcagccacagtcccatctcctccaacttcaagtgaagtttagagagttgact

$$
\begin{array}{lllllllllllllllllllll}
D & H & L & L & K & D & Y & P & V & T & V & A & V & N & L & Q & D & E & K & H
\end{array}
$$

182 gaccacctgcttaagattacccagtcactgtggccgtcaatcttcaggacgagaagcac

242 tgcaaggccttgtggagcctcttcctagcccagcgctggatagagcaactgaagactgtg $\begin{array}{llllllllllllllllllll}A & G & S & K & M & Q & T & L & L & E & D & V & N & T & E & I & H & F & V & T\end{array}$

302 gcagggtctaagatgcaaacgcttctggaggacgtcaacaccgagatacattttgtcacc 361

362 tcatgtaccttccagcccctaccagaatgtctgcgattcgtccagaccaacatctcccac 421

422 ctcctgaaggacacctgcacacagctgcttgctctgaagccctgtatcgggaaggcetgc 481 $\begin{array}{llllllllllllllllllll}Q & N & F & S & R & C & L & E & V & Q & C & Q & P & D & S & S & T & L & L & P\end{array}$

482 cagaattctctcggtgcctggaggtgcagtgccagccggactcctccaccctgctgccc $\begin{array}{lllllllllllllllllll}\mathrm{P} & \mathrm{R} & \mathrm{S} & \mathrm{P} & \mathrm{I} & \mathrm{A} & \mathrm{L} & \mathrm{E} & \mathrm{A} & \mathrm{T} & \mathrm{E} & \mathrm{L} & \mathrm{P} & \mathrm{E} & \mathrm{P} & \mathrm{R} & \mathrm{P} & \mathrm{R}\end{array}$

542 ccaaggagtcccatagccctagaagccacggagctcccagagcctcggcccagg

= cysteine involved in disulfide bonds

= Alpha helix

$=$ beta sheet 
APPENDIX B - PLACEMENT OF FORWARD AND REVERSE PRIMERS FOR FLT3L AND HIS-FLT3L

FLT3L

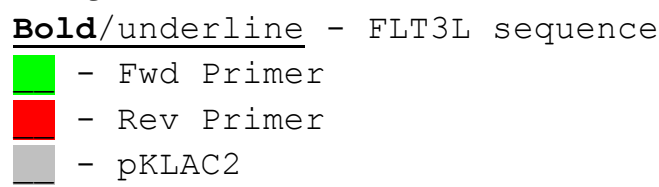

Forward Sequence:

Cttgttgcctgttaataacggaacccacactggtattctattcttaacaccaccatcgc Tgaagctgctttcgctgacaaggatgatctcgagaaaagacacctgactgttacttcag Ccacagtcccatctcctccaacttcaaagtgaagtttagagagttgactgaccacctgct Taaagattacccagtcactgtggccgtcaatcttcaggacgagaagcactgcaaggcctt Gtggagcctcttcctagcccagcgctggatagagcaactgaagactgtggcagggtctaa Gatgcaaacgcttctggaggacgtcaacaccgagatacattttgtcacctcatgtacctt Ccagcccctaccagaatgtctgcgattcgtccagaccaacatctcccacctcctgaagga Cacctgcacacagctgcttgctctgaagccctgtatcgggaaggcctgccagaatttctc Tcggtgcctggaggtgcagtgccagccggactcctccaccctgctgcccccaaggagtcc Catagccctagaagccacggagctcccagagcctcggcccaggtaagaattccctgcagg Taattaataaggccttgaatcgagaatttatacttagataagtatgtacttacaggta Tatttctatgagatactgatgtatacatgcatgataatatttaac

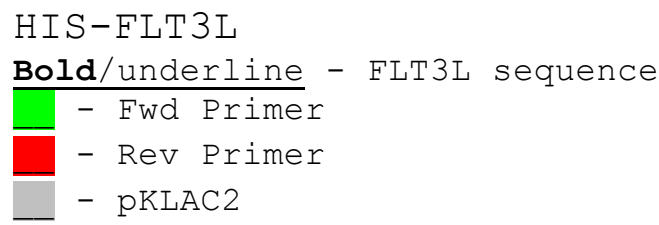

Forward Sequence:

Gttataacggaacccacactggtattctattcttaaacaccaccatcgctgaagctgctt tcgctgacaaggatgatctcgagaaaagaacacctgactgttacttcagccacagtccca tctcctccaacttcaaaGtgaagtttagagagttgactgaccacctgcttaaagattacc cagtcactgtggccgtcAatcttcaggacgagaagcactgcaaggccttgtggagcctct tcctagcccagcgctggAtagagcaactgaagactgtggcagggtctaagatgcaaacgc ttctggaggacgtcaacAccgagatacattttgtcacctcatgtaccttccagcccctac cagaatgtctgcgattcGtccagaccaacatctcccacctcctgaaggacacctgcacac agctgcttgctctgaagCcctgtatcgggaaggcctgccagaatttctctcggtgcctgg aggtgcagtgccagccgGactcctccaccctgctgcccccaaggagtcccatagccctag aagccacggagctcccaGagcctcggcccaga

attaagaattccctgcaggtaattaaataaggccttgaatcgagaatttatacttagat aagtatgtacttacaggtatatttctatgagatactgatgtatacatgcatgataatatt taaacggttattagtgccgattgtcttgtgcgataatgacgttcctatcaaagcaataca cttaccacctattacatgggccaagaaatattttcgaacttgtt 


\section{APPENDIX C - BLAST OF EXTRACELLULAR REGION OF FLT3L WITH POSITIVE SEQUENCE OBTAINED FROM MaRS.}

\section{Extracellular region of flt3l (User Entered) \\ - and - \\ FLT3L fwd (User Entered)}

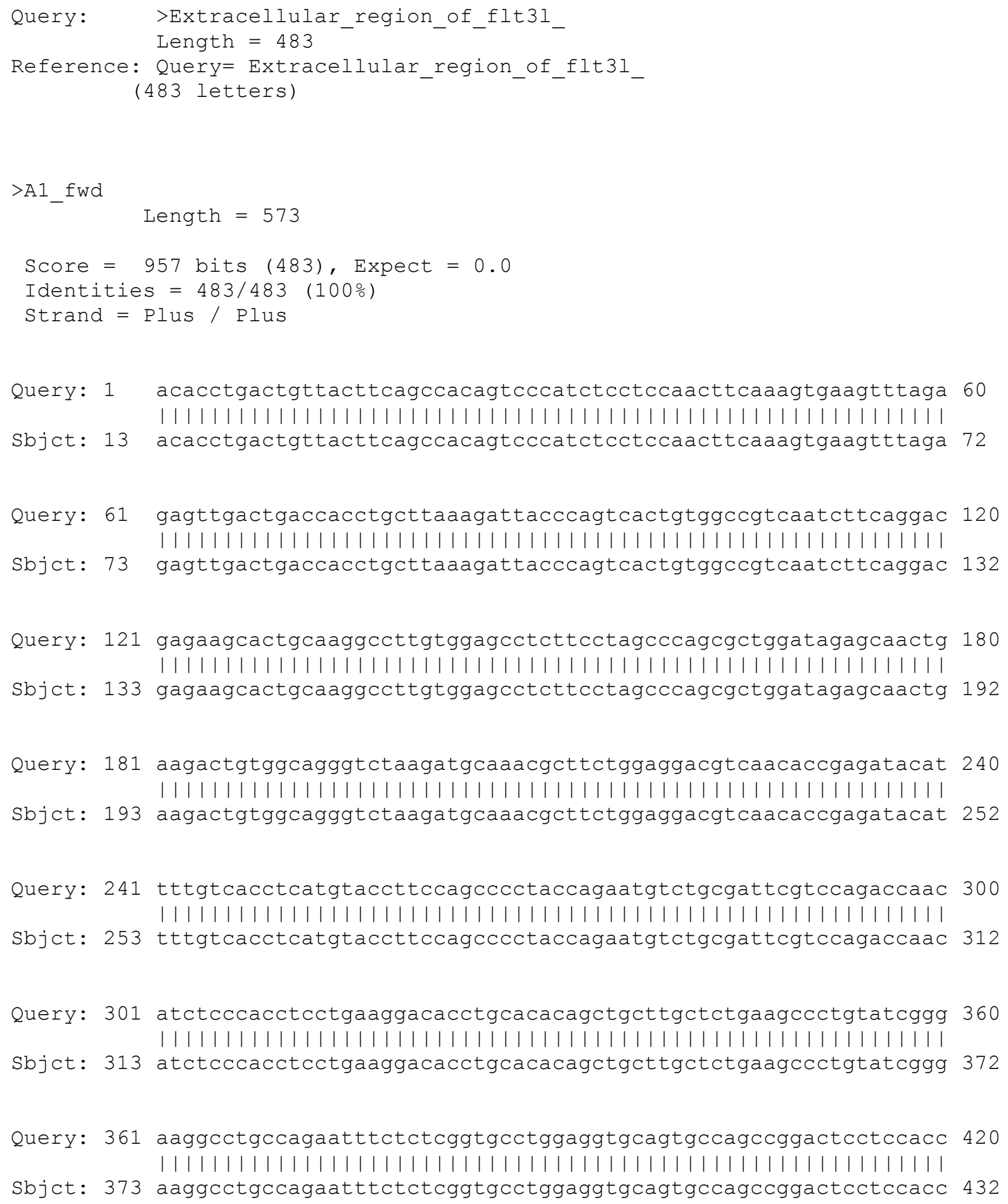




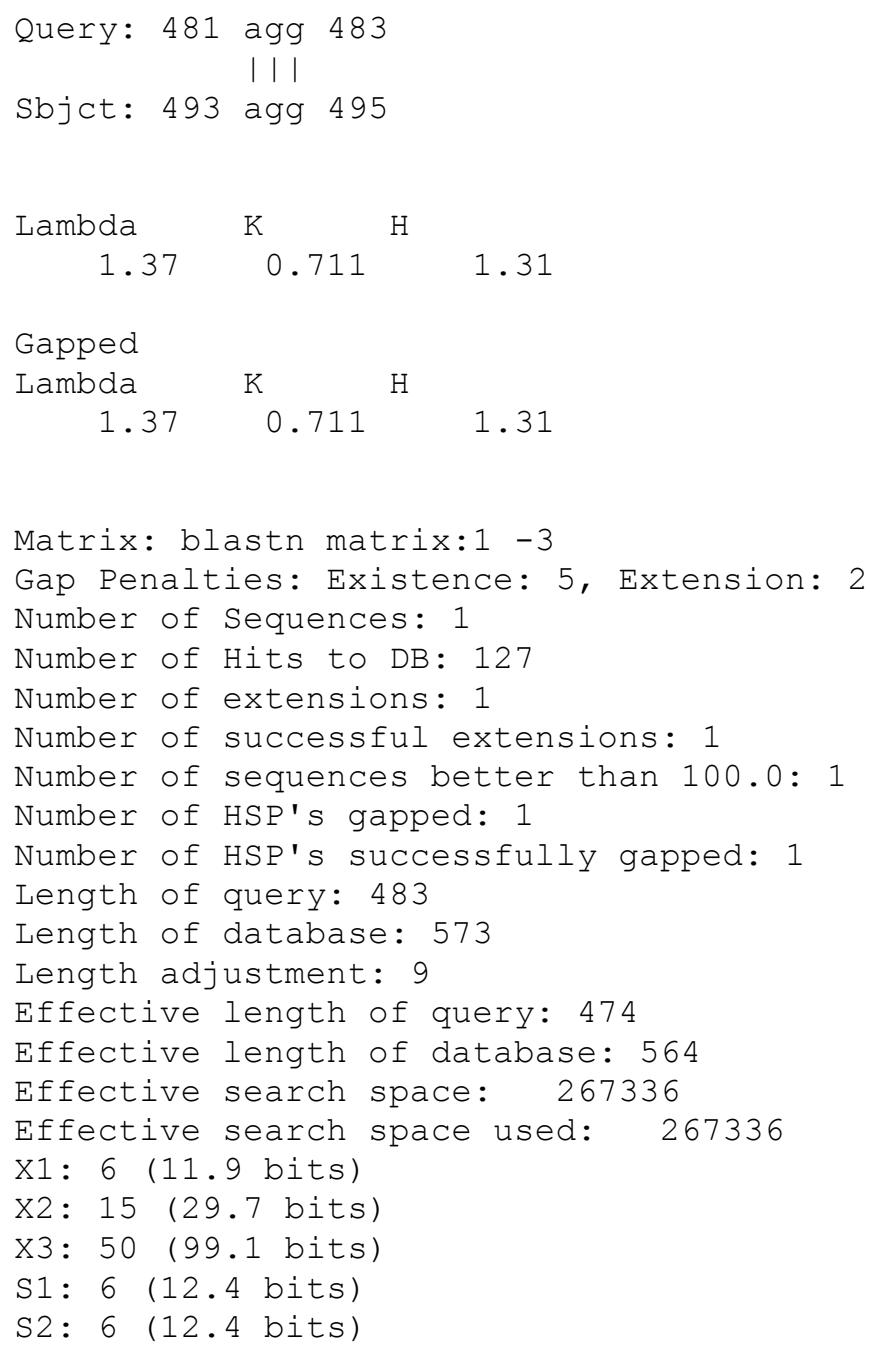




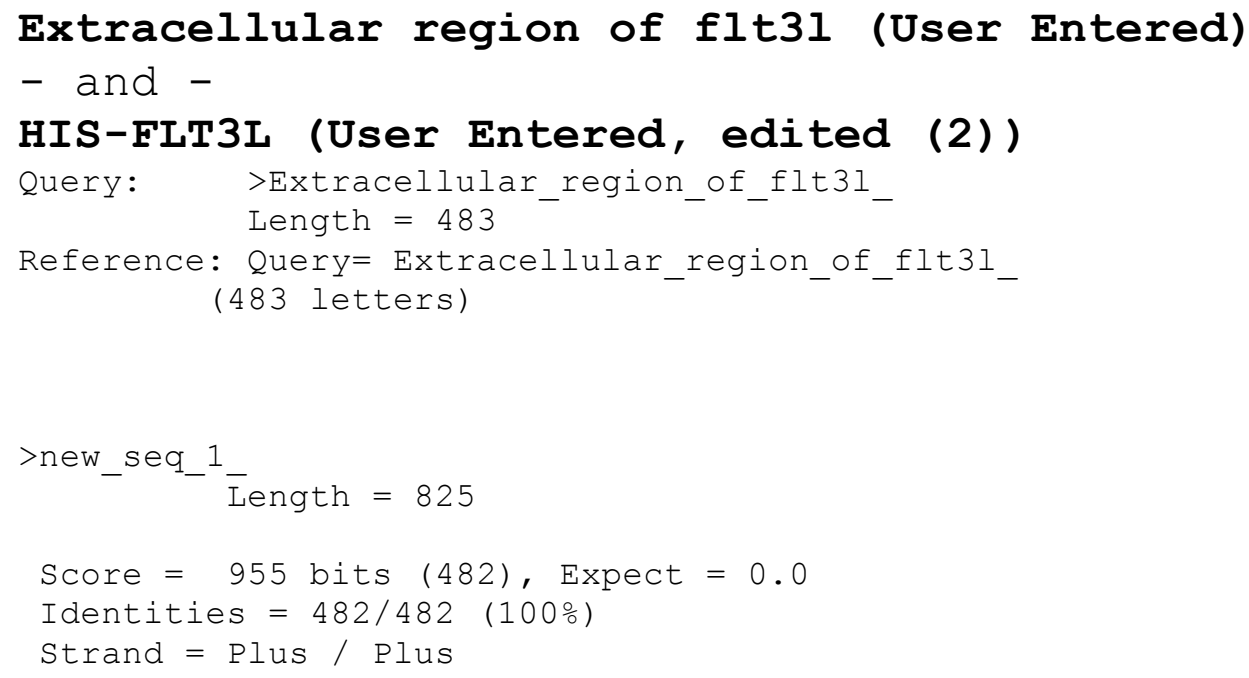

Query: 241 tttgtcacctcatgtaccttccagcccctaccagaatgtctgcgattcgtccagaccaac 300 |||||||||||||||||||||||||||||||||||||||||||||||||||||||||||||||||||

Sbjct: 330 tttgtcacctcatgtaccttccagcccctaccagaatgtctgcgattcgtccagaccaac 389

Query: 301 atctcccacctcctgaaggacacctgcacacagctgcttgctctgaagccetgtatcggg 360 ||||||||||||||||||||||||||||||||||||||||||||||||||||||||||||||||

Sbjct: 390 atctcccacctcctgaaggacacctgcacacagctgcttgctctgaagccctgtatcggg 449

Query: 361 aaggcctgccagaatttctctcggtgcctggaggtgcagtgccagccggactcctccacc 420 ||||||||||||||||||||||||||||||||||||||||||||||||||||||||||||||||

Sbjct: 450 aaggcctgccagaatttctctcggtgcctggaggtgcagtgccagccggactcctccacc 509

Query: 421 ctgctgcccccaaggagtcccatagccctagaagccacggagctcccagagcctcggcc 480 |||||||||||||||||||||||||||||||||||||||||||||||||||||||||||||||||||

Sbjct: 510 ctgctgcccccaaggagtcccatagccctagaagccacggagctcccagagcctcggecc 569 


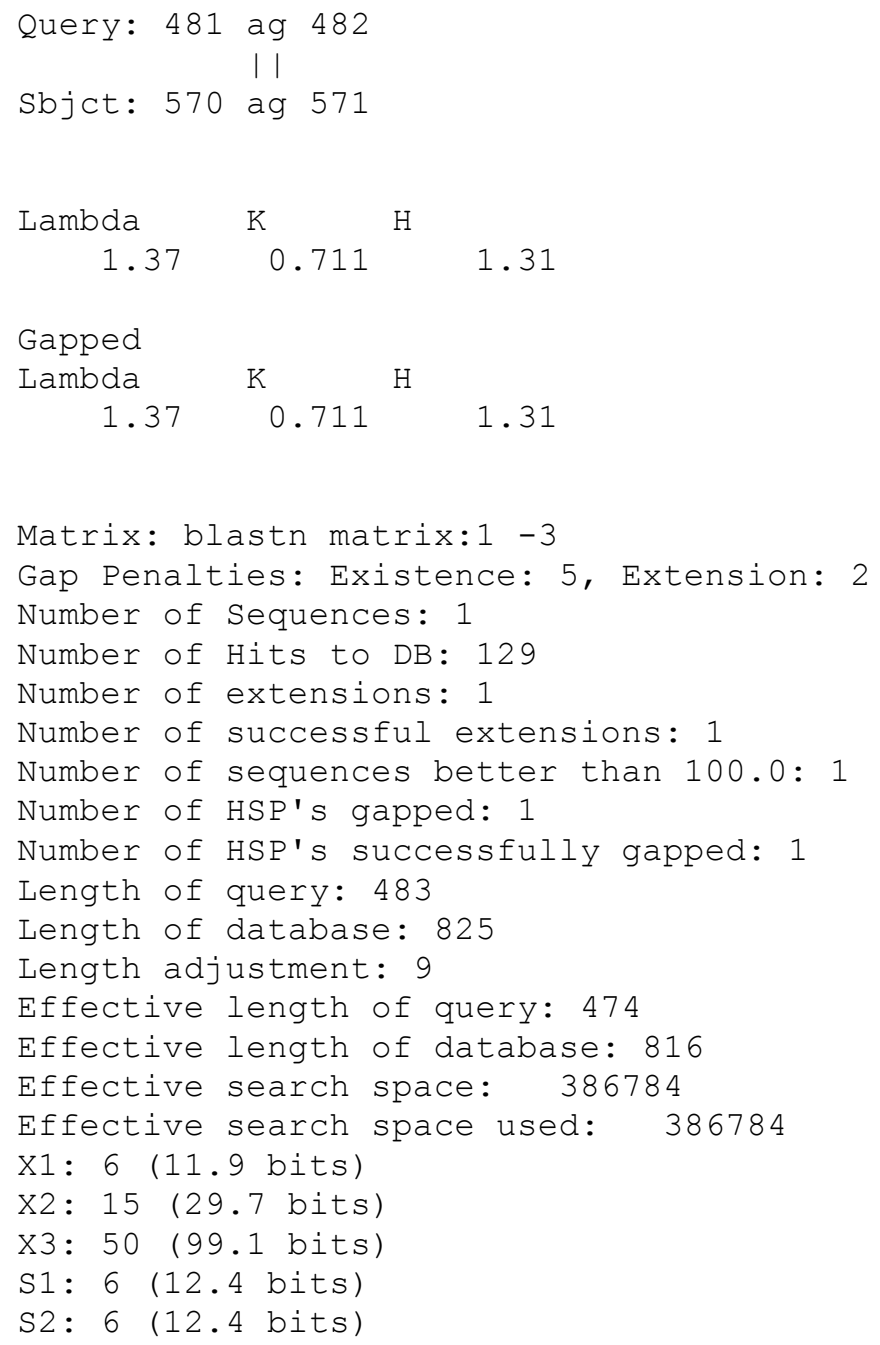




\section{APPENDIX D - TRANSLATED CONFIRMED SEQUENCE OPEN READING FRAME OF FLT3L AND HIS-FLT3L}

\section{Frame 1, 3 stop codons}

\section{FLT3L}

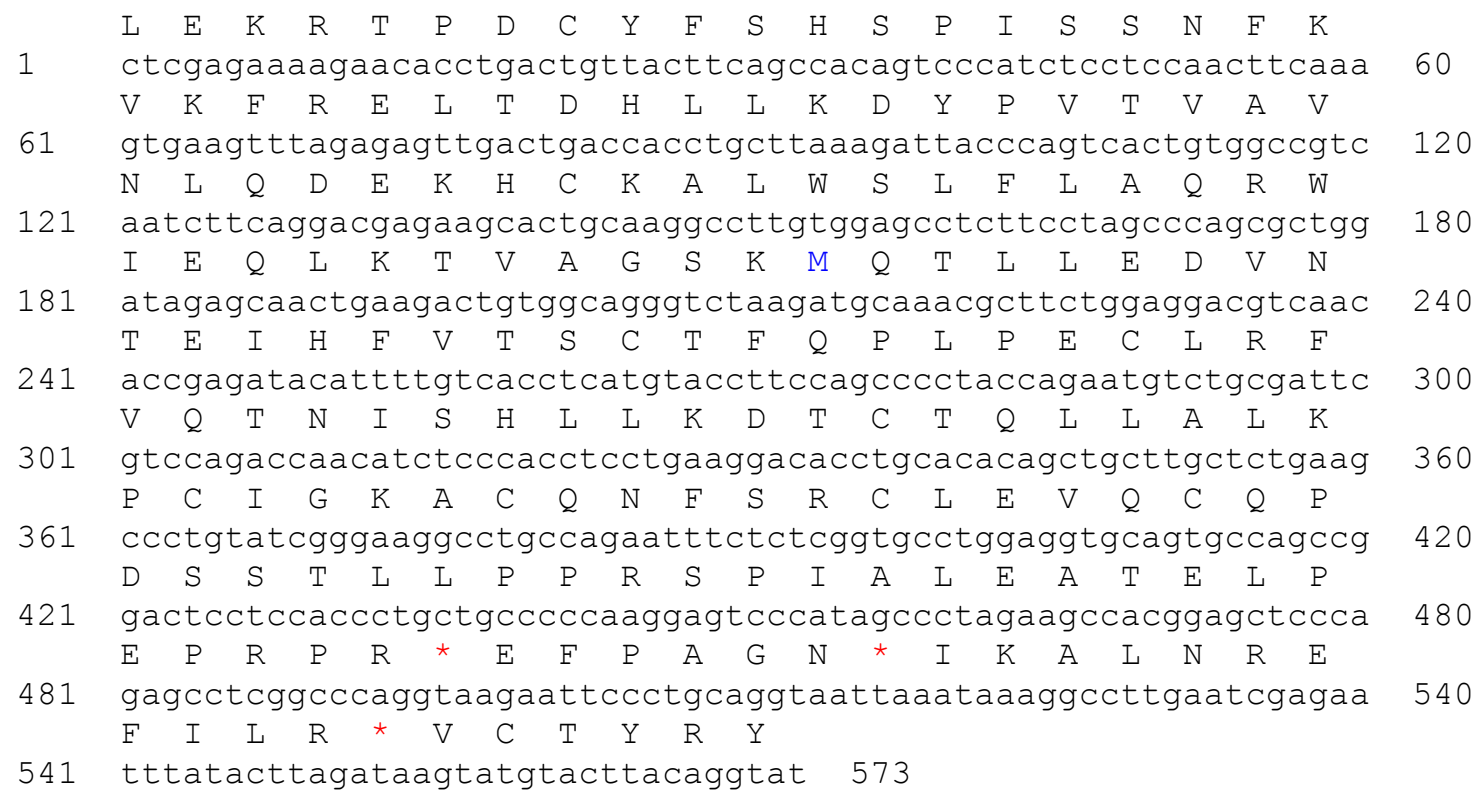




\section{Frame 3, 7 stop codons}

\section{HIS-FLT3L}

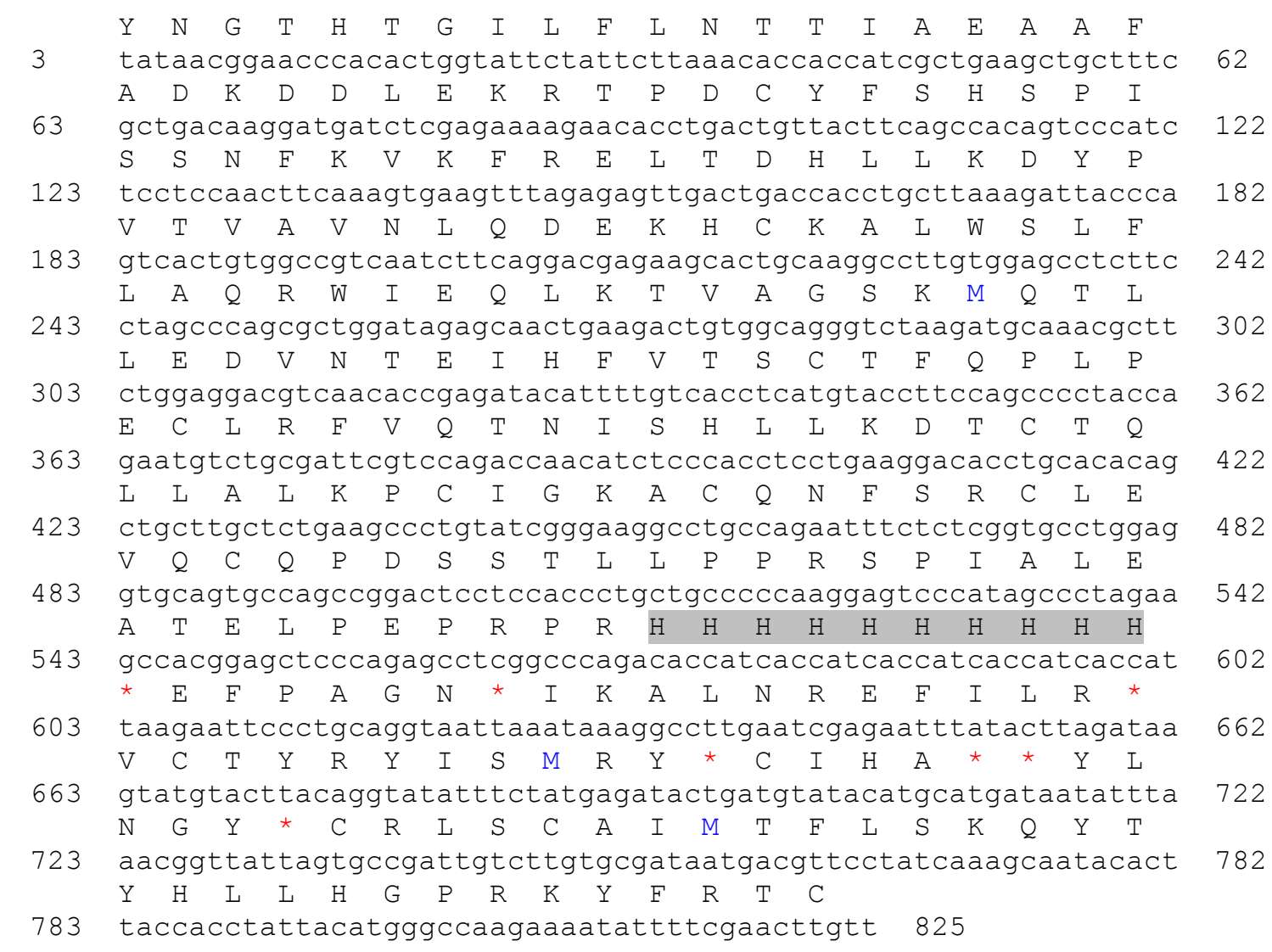




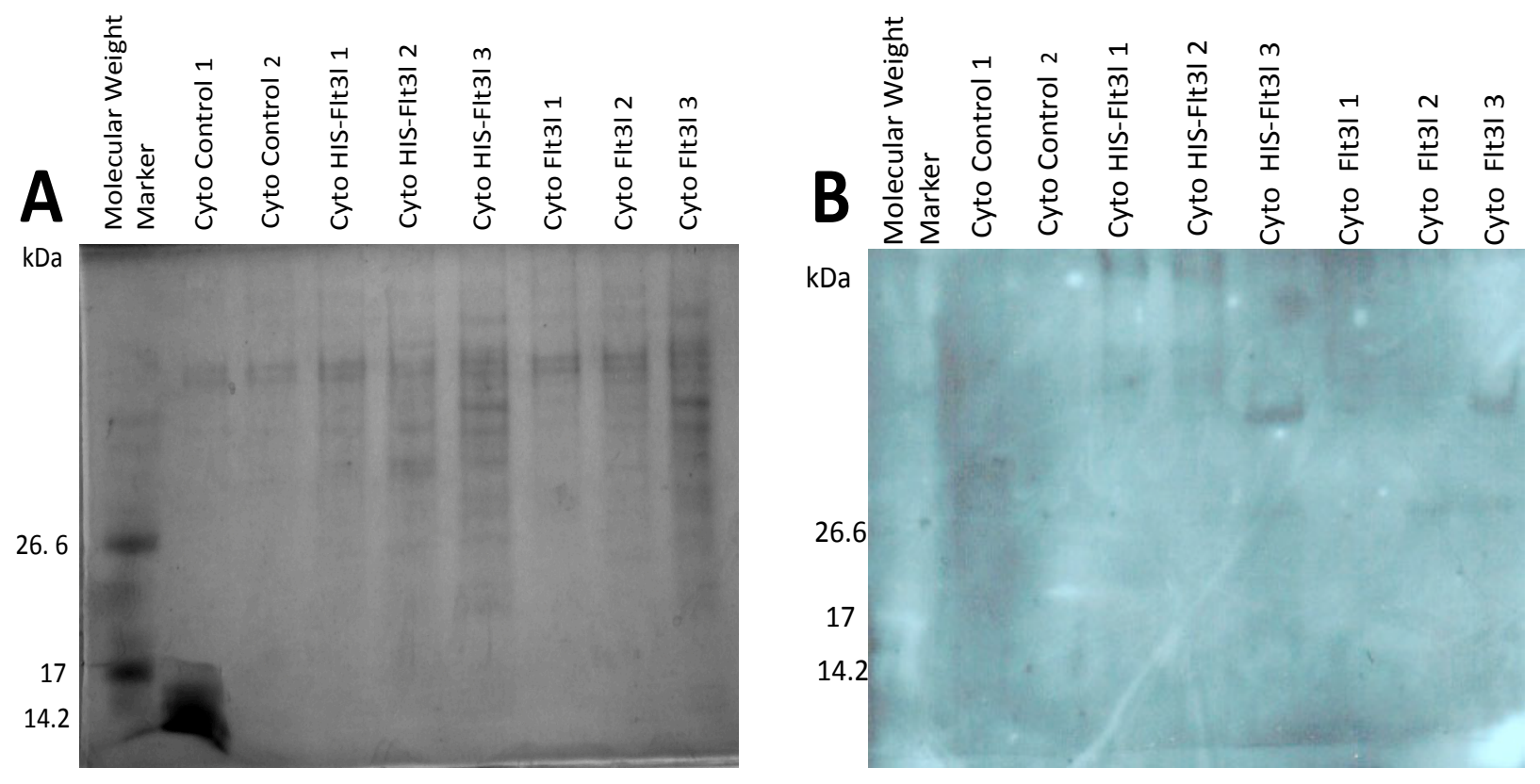

Figure 24. 9\% (A) SDS-PAGE and (B) Western blot of the cytosol of a control strains of yeast , 3 strains of HIS-FLT3L yeast, and 3 strains of FLT3L yeast.
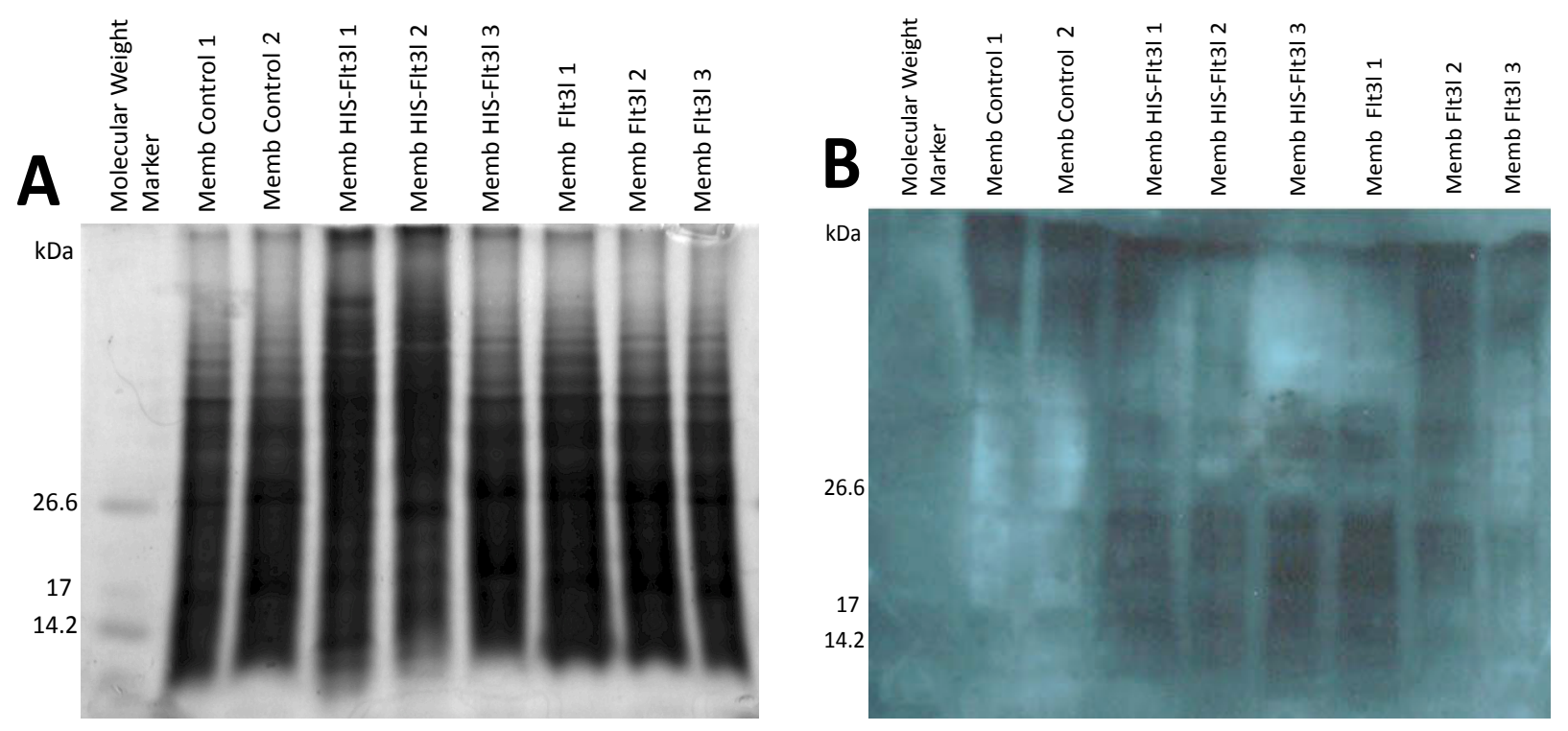

Figure 25. 9\% (A) SDS-PAGE and (B) Western blot of the membranes of a control strains of yeast , 3 strains of HIS-FLT3L yeast, and 3 strains of FLT3L yeast. 


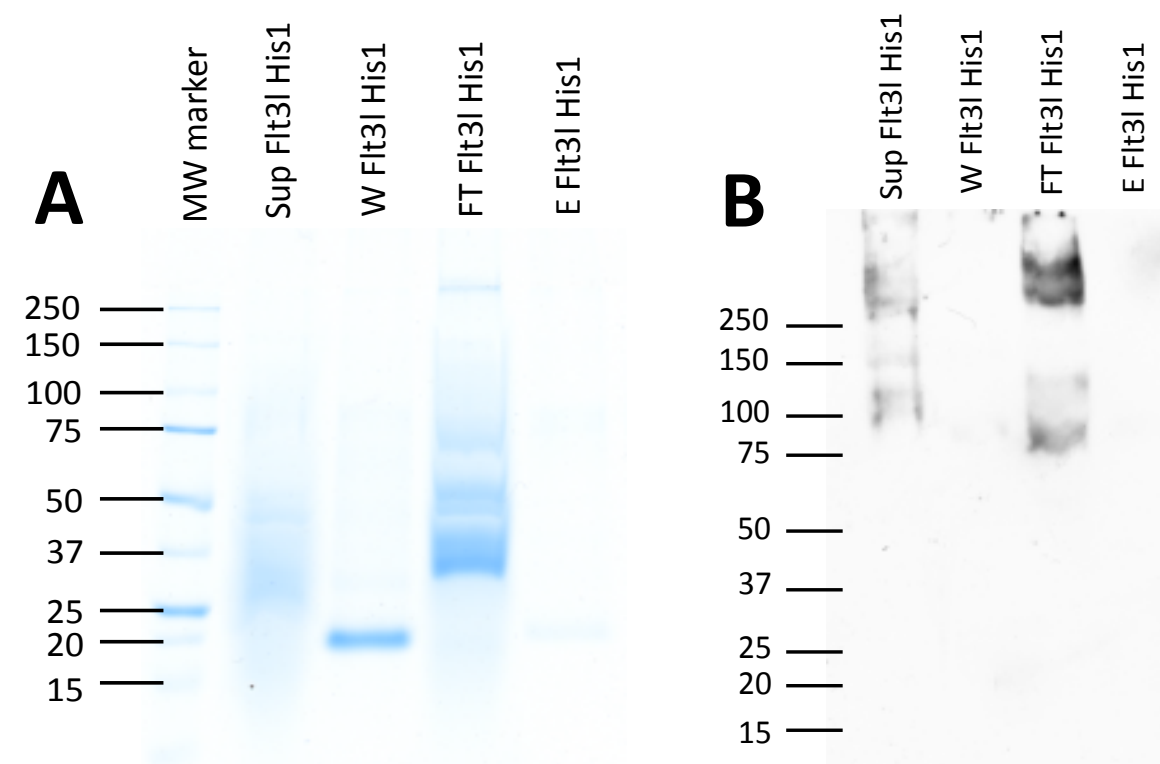

Figure 26. (A) 9\% Coomassie stained SDS-PAGE of HIS-FLT3L supernatant and all other fractions after Ni-affinity chromatography ( $1 \mathrm{~mL} \mathrm{Ni)}$. Column was washed with $10 \mathrm{mM}$ phosphate buffer containing $20 \mathrm{mM}$ imidazole and eluted with $10 \mathrm{mM}$ phosphate buffer containing $250 \mathrm{mM}$ imidazole. (B) Corresponding western blot using an anti-FLT3L monoclonal antibody (R\&D Systems)

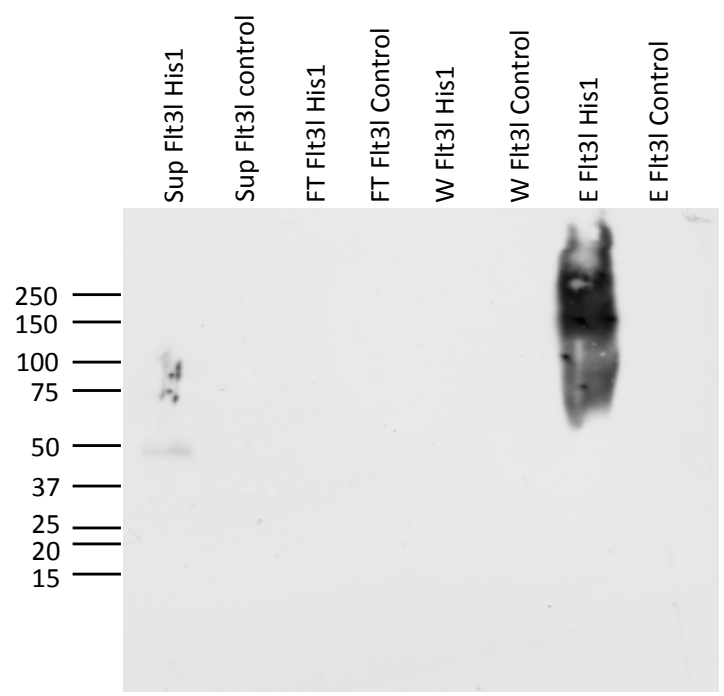

Figure 27. Western blot of Ni-affinity chromatography fractions from FLT3L-HIS 1 alongside a control. 


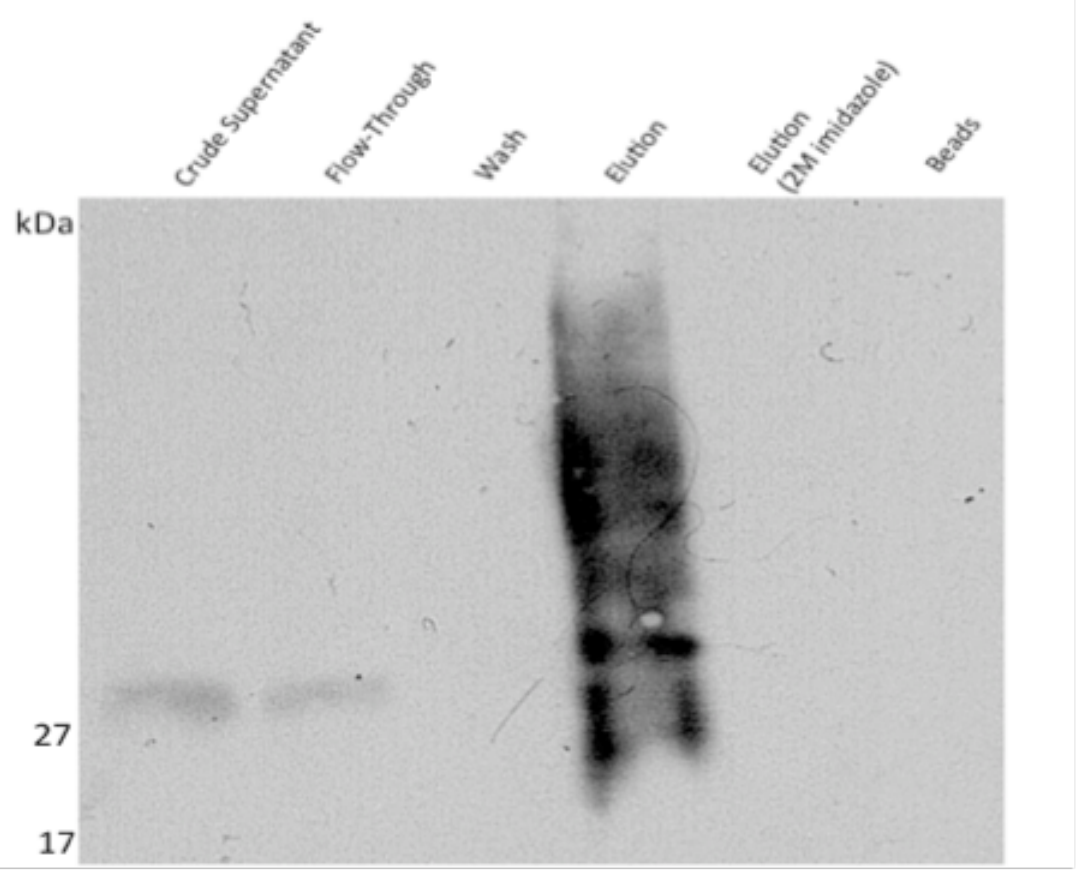

Figure 28. Western blot of HIS-FLT3LpKLAC2 fractions after Ni-affinity chromatography. Supernatant $(150 \mathrm{~mL})$ was collected and dialyzed against $10 \mathrm{mM}$ phosphate buffer $(\mathrm{pH} 8)$ to a final $\mathrm{pH}$ of 7.7 and subjected to a $1.5 \mathrm{~mL}$ Ni-column. Column was washed with $10 \mathrm{mM}$ phosphate buffer containing $20 \mathrm{mM}$ imidazole and eluted with $10 \mathrm{mM}$ phosphate buffer containing $250 \mathrm{mM}$ imidazole. Western was performed using an anti-FLT3L murine monoclonal antibody (R\&D systems). 


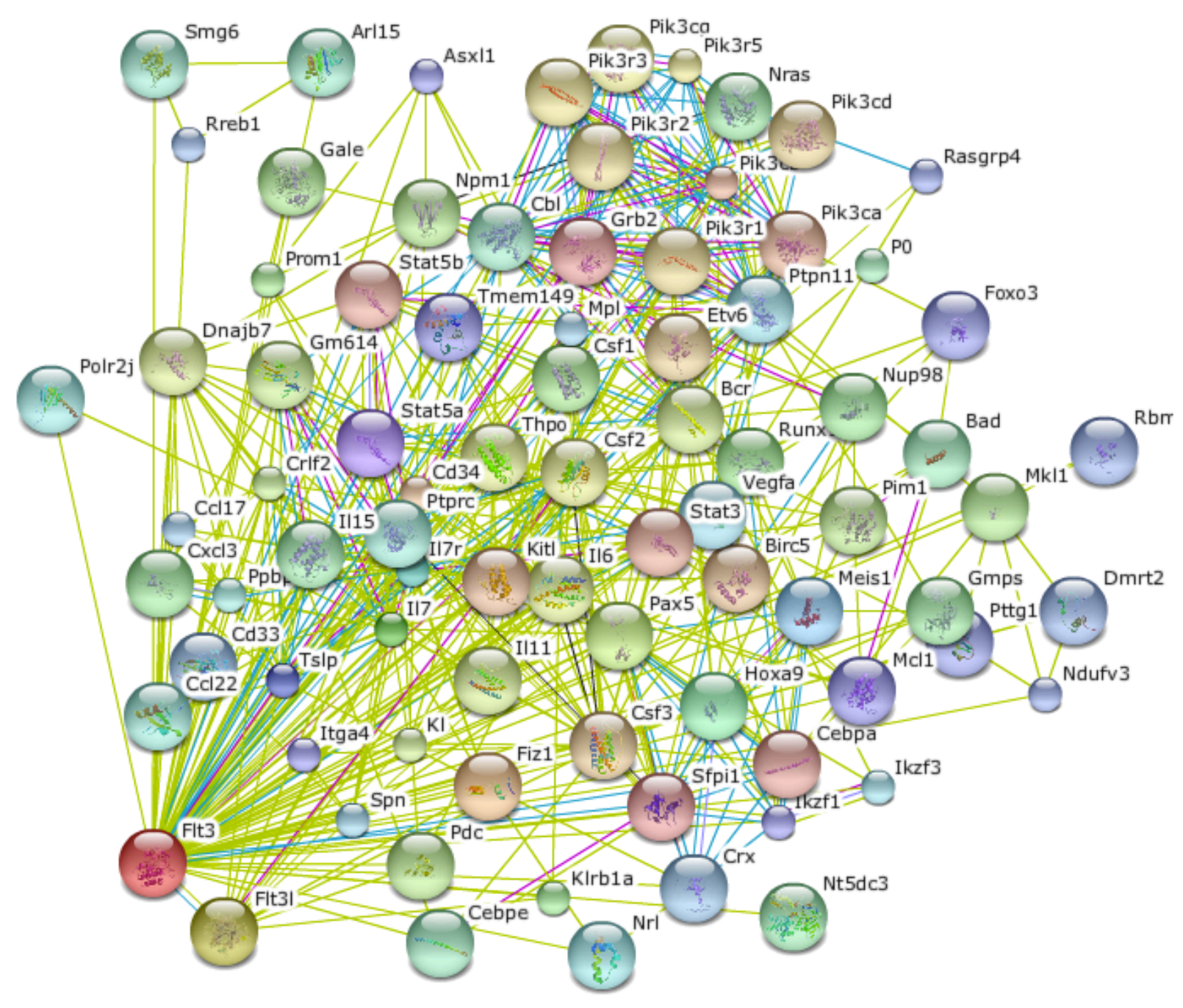

Figure 29. Model of FLT3 murine receptor interactors predicted by STRING 9.0 based on textmining information. (STRING 9.0 is developed by Szklarczyk et al. (2010)) 


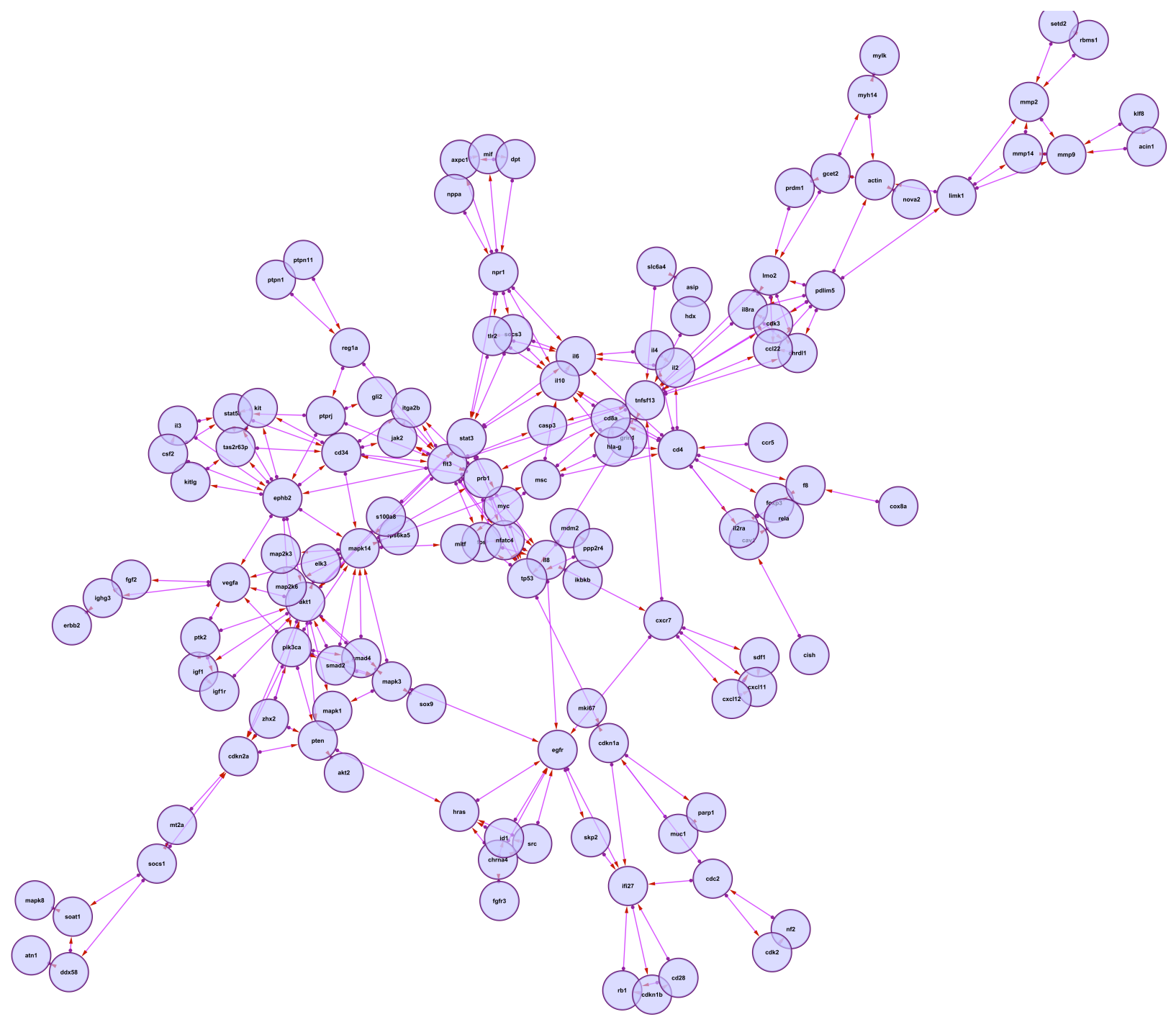

Figure 30. Model of FLT3 human ligand interactors predicted by Cytoscape based on textmining information. Display is in 'organic' which facilitates identification of clusters of proteins that are shown to be highly interactive. (Cytoscape is developed by Shannon et al (2003)) 
Table 5. RAW264.7 Data from an IgG LARC experiment.

\begin{tabular}{|c|c|c|c|c|}
\hline \multirow{3}{*}{$\# 15643$} & Identified Protein & Sequences Identified & Score & \\
\hline & \multicolumn{2}{|c|}{ FMS-like tyrosine kinase 3 [Mus musculus] } & 349.60 & 6753888.0 \\
\hline & rawextr_chlfbeadIgG_Mar04, 598 & TGVSIQVAVKMLK & 1.69 & 0.0 \\
\hline \multirow[t]{4}{*}{ \#10682 } & \multicolumn{2}{|c|}{ FMS-like tyrosine kinase 3 [Mus musculus] } & 451.31 & 6753888.0 \\
\hline & & .PSFPNLTSFLGCQLA & & \\
\hline & phagrawF200_dec22, 2119 & EAEEACIR & 1.23 & 0.1 \\
\hline & $\begin{array}{l}\text { rawsucrfp_300phagigg_Mar04, } \\
2359\end{array}$ & $\begin{array}{l}\text { TWTEIFKEHNFSSYP } \\
\text { TFQAHSNSSMPGSR }\end{array}$ & 1.06 & 0.1 \\
\hline \multirow[t]{8}{*}{ \#3281 } & \multicolumn{2}{|c|}{ FMS-like tyrosine kinase 3 [Mus musculus] } & 2470.15 & 6753888.0 \\
\hline & jmrawigg 5 minbeadsyringdnase, 41 & VFGQWVSSSTLNM & & \\
\hline & $3-415$ & SEAGK & 2.28 & 0.0 \\
\hline & & VMNATAYGISKTGV & & \\
\hline & jmfag5minigg350mmnacl, 675 & SIQVAVK & 1.50 & 0.0 \\
\hline & & QASFPCEQR & & \\
\hline & JMFAGNACL10_2B21E3, 2030 & GLEDGYSISK & 1.64 & 0.0 \\
\hline & jmfag5minigg200mmnacl, 2822 & $\begin{array}{l}\text { NDTGYYTCSSSKHPS } \\
\text { QSALVTILEK }\end{array}$ & 1.04 & 0.1 \\
\hline \multirow[t]{4}{*}{ \#9150 } & \multicolumn{2}{|c|}{ Fms interacting protein [Mus musculus] I, alpha po } & 1098.92 & 24980875.0 \\
\hline & jmfag5minigg $150 \mathrm{mmnacl}, 330$ & MSSESSK & 1.16 & 0.1 \\
\hline & $\begin{array}{l}\text { jmrawigg } 5 \mathrm{~min} 300 \mathrm{~mm} \text { naclsyringed } \\
\text { nase } 441\end{array}$ & GEKTNSNDDNIRAM & & \\
\hline & jmIgG150rawphag3007,1704-1706 & HPLSVLLDLKCK & 1.31 & 0.1 \\
\hline
\end{tabular}

* Work done by Albana Kume. 
APPENDIX H - BSA CALIBRATION CURVE AND CALCULATIONS

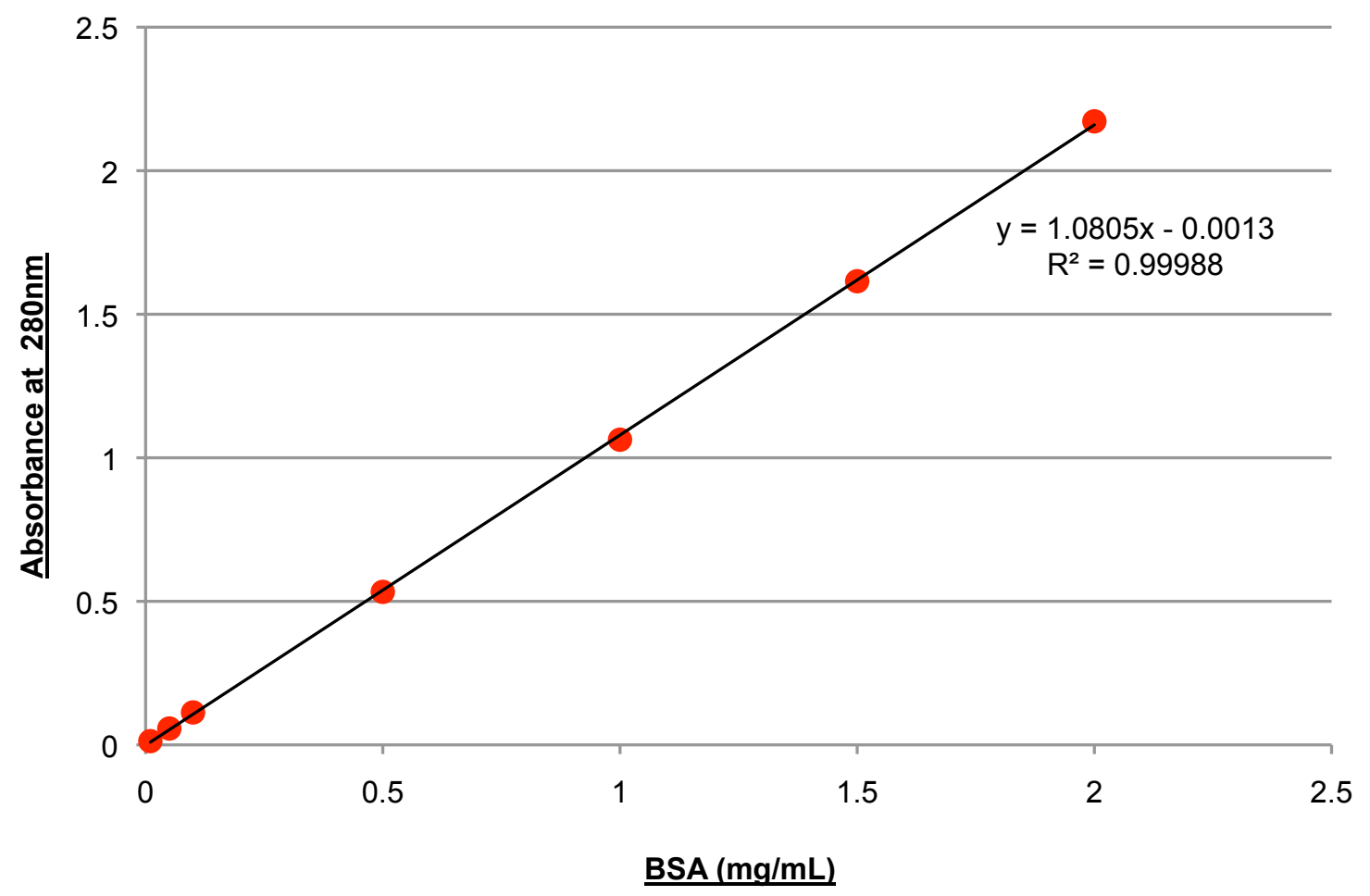

Figure 31. BSA calibration curve for spectrophotomeric protein assay.

Calculations:

Control

$0.1745=1.0805 \mathrm{x}-0.0013$

$\mathrm{x}=0.1627 \mathrm{mg} / \mathrm{mL} \mathrm{x}(10 \mathrm{x}$ dilution $)$

$=1.6270 \mathrm{mg} / \mathrm{mL}$

HIS-FLT3L

$0.3527=1.0805 \mathrm{x}-0.0013$

$\mathrm{x}=0.3294 \mathrm{mg} / \mathrm{mL} \mathrm{x}(10 \mathrm{x}$ dilution $)$

$=3.294 \mathrm{mg} / \mathrm{mL}$ 


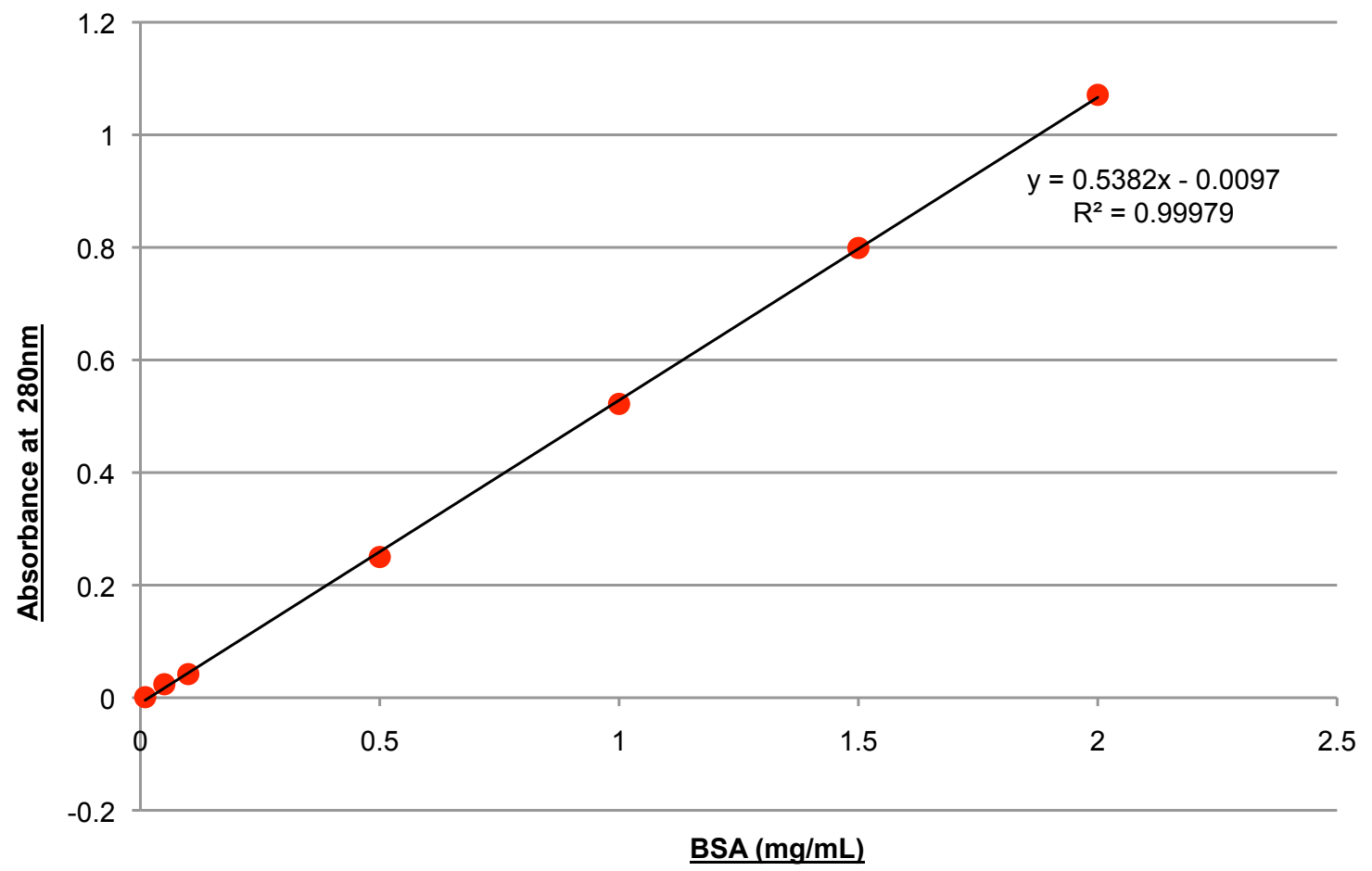

Figure 32. BSA calibration curve for spectrophotomeric protein assay (II). Dilute dried sample in 500uL purified (Filtered HPLC) H2O, used 5:45 for spec readings.

Sample \#1 (HIS-FLT3L)

$\mathrm{y}=0.5382 \mathrm{x}-0.0097$

$(0.057+0.0097) / 0.5382=0.12393$

$0.12393 \times 10$ dilution factor $=1.2393 \mathrm{mg} / \mathrm{mL}$

Sample \#2 (HIS-FLT3L)

$\mathrm{y}=0.5382 \mathrm{x}-0.0097$

$(0.208+0.0097) / 0.5382=0.40449$

$0.40449 \times 10$ dilution factor $=4.0449 \mathrm{mg} / \mathrm{mL}$

Controls $(1,2,3) \mathrm{A}=1.990,2.694 .2 .999$ (dilution factor = 26)

$\# 1=97.58 \mathrm{mg} / \mathrm{mL}$

$\# 2=130.6 \mathrm{mg} / \mathrm{mL}$

$\# 3=145.38 \mathrm{mg} / \mathrm{mL}$ 


\section{REFERENCES}

Abu-Duhier, F. M. et al. (2001). Genomic structure of human FLT3: implications for mutational analysis. Br. J. Haematol, 113, 1076-1077.

Abu-Duhier, F. M. et al. (2000). FLT3 internal tandem duplication mutations in adult acute myeloid leukaemia define a high risk group. Br. J. Haematol, 111, 190-195.

Agnes, F. et al. (1994). Genomic structure of the downstream part of the human FLT3 gene: exon/intron structure conservation among genes encoding receptor tyrosine kinases (RTK) of subclass III. Gene, 145, 283-288.

Armstrong, S. A. et al. (2002). MLL translocations specify a distinct gene expression profile that distinguishes a unique leukemia. Nature Genet, 30, 41-47.

Ashihara, E. et al. (1998). FLT-3 ligand mobilizes hematopoietic primitive and committed progenitor cells into blood in mice. Eur. J. Haematol, 60, 86-92.

Astier AL. et al. (2010). RNA interference screen in primary human T cells reveals FLT3 as a modulator of IL10 levels. J Immunol, 184, 685-693.

Bradford, M. (1976). A rapid and sensitive method for the quantitation of microgram quantities of protein utilizing the principle of protein-dye binding. Anal Biochem, 72. 248-254.

Brasel, K. et al. (1995). Expression of the flt3 receptor and its ligand on hematopoietic cells. Leukemia, 9, 1212-1218.

Brown P. et al. (2004). Pediatric AML primary samples with FLT3/ITD mutations are preferentially killed by FLT3 inhibition. Blood, 104, 1841-1849.

Carow, C. E. et al. (1996). Expression of the hematopoietic growth factor receptor FLT3 (STK1/Flk2) in human leukemias. Blood, 87, 1089-1096.

Carotta S. et al. (2010). The transcription factor PU.1 controls dendritic cell development and Flt3 cytokine receptor expression in a dose-dependent manner. Immunity, 32, 628-641.

Chakravarty, P. K. et al. (1999). Flt3-ligand administration after radiation therapy prolongs survival in a murine model of metastatic lung cancer. Cancer Res., 59, 6028-6032.

Chaudhry UI. et al. (2006). In vivo overexpression of Flt3 ligand expands and activates murine spleen natural killer dendritic cells. FASEB J, 20, 982-984.

Chen, K. et al. (1997). Antitumor activity and immunotherapeutic properties of Flt3-ligand in a murine breast cancer model. Cancer Res., 57, 3511-3516. 
Chen P. et al. (2005). FLT3/ITD mutation signaling includes suppression of SHP-1. J Biol Chem, 280, 5361-5369.

Cox, N. \& Nelson, D. (2008). Lehninger principles of biochemistry $\left(4^{\text {th }}\right.$ ed.) New York, NY: W. H. Freeman.

Daro E. et al. (2002). Comparison of the functional properties of murine dendritic cells generated in vivo with Flt3 ligand, GM-CSF and Flt3 ligand plus GM-CSF. Cytokine, 17, 119-130.

Della Bella S. et al. (2004). Are interleukin-16 and thrombopoietin new tools for the in vitro generation of dendritic cells? Blood, 104, 4020-4028.

Dosil, M. et al. (1993). Mitogenic signalling and substrate specificity of the Flk2/Flt3 receptor tyrosine kinase in fibroblasts and interleukin-3-dependent hematopoietic cells. Mol. Cell. Biol., 13, 6572-6585.

Drexler H. et al. (1999). Effects of FLT\# ligand on proliferation and survival of myeloid leukemia cells. Leukemia and Lymphoma, 33, 83-91.

Foran, J. et al. (2002). An innovative single dose clinical study shows potent inhibition of FLT3 phosphorylation by SU11248 in vivo: a clinical and pharmacodynamic study in AML patients. Blood, 100, 2196 a.

Gabbianelli, M. et al. (1995). Multi-level effects of flt3 ligand on human hematopoiesis: expansion of putative stem cells and proliferation of granulomonocytic progenitors/monocytic precursors. Blood, 86, 1661-1670.

Gille, H. et al. (2000). A repressor sequence in the juxtamembrane domain of Flt-1 (VEGFR-1) constitutively inhibits vascular endothelial growth factor-dependent phosphatidylinositol 3'-kinase activation and endothelial cell migration. EMBO J, 19, 4064-4073.

Gonfloni, S. et al. (2000). Crosstalk between the catalytic and regulatory domains allows bidirectional regulation of Src. Nature Struct. Biol., 7, 281-286.

Graddis, TJ. et al. (1998). Structure-Function analysis of FLT3 ligand-FLT3 receptor interactions using a rapid functional screen. J. Biol. Chem., 273, 17626-17633.

Griffith J. et al. (2004). The structural basis for autoinhibition of FLT3 by the juxtamembrane domain. Mol. Cell., 13, 169-178.

Grundler, R. et al. (2005). FLT3-ITD and tyrosine kinase domain mutants induce 2 distinct phenotypes in a murine bone marrow transplantation model. Blood, 105, 4792-4799.

Haak-Frendscho M. et al. (1990). Transforming growth factor-fit inhibits activation of macrophage cell line RAW 264.7 for cell killing. Clin.exp.Immunol., 82, 404-410. 
Haan, C \& Iris, B. (2007). A cost effective non-commercial ECL-solution for western blot detections yielding strong signals and low background. J of Immunological Methods, 318, 11-19.

Hanahan D. (1983). Studies on transformation of Escherichia coli with plasmids. J Mol Biol, 4, 373-384.

Hannum, C. et al. (1994). Ligand for FLT3/FLK2 receptor tyrosine kinase regulates growth of haematopoietic stem cells and is encoded by variant RNAs. Nature, 368, 643-648.

Hayakawa, F. et al. (2000). Tandem-duplicated Flt3 constitutivelya ctivates STAT5 and MAP kinase and introduces autonomous cell growth in IL-3-dependent cell lines. Oncogene, 19, 624-631.

Heiss E. et al. (2006). Indentification of Y589 and Y599 in the juxtamembrane domain of Flt3 as ligand-induced autophosphorylation sites involved in binding of Src family kinases and the protein tyrosine phosphatase SHP2. Blood, 5, 1542-1550.

Hjertson, M. et al. (1996). Stem cell factor, but not flt3 ligand, induces differentiation and activation of human mast cells. Exp. Hematol., 24, 748-754.

Holmes ML. et al. (2006). Repression of Flt3 by Pax5 is crucial for B-cell lineage commitment. Genes \& Dev., 20, 933-938.

Horiike, S. et al. (1997). Tandem duplications of the FLT3 receptor gene are associated with leukemic transformation of myelodysplasia. Leukemia, 11, 1442-1446.

Horiuchi K, et. al. (2009). Ectodomain Shedding of FLT3 Ligand Is Mediated by TNF- $\alpha$ Converting Enzyme. The Journal of Immunology, 182, 7408-7414.

Inomata, M. et al. (2006). Inverse correlation between Flt3 and PU.1 expression in acute myeloblastic leukemias. Leuk. Res., 30, 659-664.

Irish JM. et al. (2007). Flt3 Y591 duplication and Bcl-2 overexpression are detected in acute myeloid leukemia cells with high levels of phosphorylated wild-type p53. Blood, 109, 2589-2596.

Iwai, T. et al. (1999). Internal tandem duplication of the FLT3 gene and clinical evaluation in childhood acute myeloid leukemia. Leukemia, 13, 38-43.

Jankowski A. et al. (2008). Capture of an activated receptor complex from the surface of live cells by affinity receptor chromatography. Analytical biochemistry. Analytical Biochem, $380,235-248$. 
Karsunky, H. et al. (2003). Flt3 ligand regulates dendritic cell development from Flt3+ lymphoid and myeloid-committed progenitors to Flt3+ dendritic cells in vivo. J. Exp. Med, 198, 305-313.

Kelly, L. M. et al. (2002a). FLT3 internal tandem duplication mutations associated with human acute myeloid leukemias induce myeloproliferative disease in a murine bone marrow transplant model. Blood, 99, 310-318.

Kelly, L. M. et al. (2002b). PML/RAR and FLT3-ITD induce an APL like disease in a mouse model. Proc. Natl Acad. Sci. USA, 99, 8283-8288.

Kelly, L. et al. (2002c). CT53518, a novel selective FLT3 antagonist for the treatment of acute myelogenous leukemia (AML). Cancer Cell, 1, 421-432.

Kindler, T. et al. (2005). Identification of a novel activating mutation (Y842C) within the activation loop of FLT3 in patients with acute myeloid leukemia. Blood, 105, 335-340.

Kim, KT. et al. (2005). Pim-1 is up-regulated by constitutively activated FLT3 and plays a role in FLT3- mediated cell survival. Blood, 105, 1759-1767.

Kiyoi, H. et al. (1998). Internal tandem duplication of the FLT3 gene is a novel modality of elongation mutation which causes constitutive activation of the product. Leukemia, 12, 1333-1337.

Kiyoi, H. et al. (1997). Internal tandem duplication of FLT3 associated with leukocytosis in acute promyelocytic leukemia. Leukemia Study Group of the Ministry of Health and Welfare (Kohseisho). Leukemia, 11, 1447-1452.

Kiyoi, H. et al. (1999). Prognostic implication of FLT3 and N-RAS gene mutations in acute myeloid leukemia. Blood, 93, 3074-3080.

Kiyoi, H. et al. (2002). Mechanism of constitutive activation of FLT3 with internal tandem duplication in the juxtamembrane domain. Oncogene, 21, 2555-2563.

Koller, A. et.al. (2002). Yates III, Proteomic survey of metabolic pathways in rice. Proc. Natl. Acad. Sci. USA, 99, 11969- 11974.

Kondo, M. et al. (1999). Prognostic value of internal tandem duplication of the FLT3 gene in childhood acute myelogenous leukemia. Med. Pediatr. Oncol., 33, 525-529.

Kottaridis, P. D. et al. (2001). The presence of a FLT3 internal tandem duplication in patients with acute myeloid leukemia (AML) adds important prognostic information to cytogenetic risk group and response to the first cycle of chemotherapy: analysis of 854 patients from the United Kingdom Medical Research Council AML 10 and 12 trials. Blood, 98, 1752-1759. 
Knudson, A. G. et al. (1975). Mutation and childhood cancer: a probabilistic model for the incidence of retinoblastoma. Proc. Natl Acad. Sci. USA, 72, 5116-5120.

Krstovski N. et al. (2009). Incidence of FLT3 and nucleophosmin gene mutations in childhood acute myeloid leukemia: Serbian experience and the review of literature. Medical Oncology, 3, 640-645.

Lavagna-Sevenier, C. et al. (1998). FLT3 signalling in hematopoietic cells involves CBL, SHC and an unknown P115 as prominent tyrosine phosphorylated substrates. Leukemia, 12, $301-310$.

Levis, M. et al. (2002). A FLT3-targeted tyrosine kinase inhibitor is cytotoxic to leukemia cells in vitro and in vivo. Blood, 99, 3885-3891.

Levis, M. et al. (2001). FLT3-targeted inhibitors kill FLT3-dependent modeled cells, leukemiaderived cell lines, and primary AML blasts in vitro and in vivo. Blood, 89, 721a.

Libura, M. et al. (2003). FLT3 and MLL intragenic abnormalities in AML reflect a common category of genotoxic stress. Blood, 102, 2198-2204.

Lisovsky, M. et al. (1996). Flt3 ligand stimulates proliferation and inhibits apoptosis of acute myeloid leukemia cells: regulation of Bcl-2 and Bax. Blood, 88, 3987-3997.

Luo J. et al. (2010). Cytoplasmic expression of nucleophosmin accurately predicts mutaion in the nucleophosmin gene in patients with acute myeloid leukemia and normal karyotype. AJCP, 133, 34-40.

Lyman, S. D. et al. (1993a). Characterization of the protein encoded by the flt3 (flk2) receptorlike tyrosine kinase gene. Oncogene, 8, 815-822.

Lyman, S. D. et al. (1993b). Molecular cloning of a ligand for the flt3/flk-2 tyrosine kinase receptor: a proliferative factor for primitive hematopoietic cells. Cell, 75, 1157-1167.

Lyman, S. D. et al. (1994a). The flt3 ligand: a hematopoietic stem cell factor whose activities are distinct from steel factor. Stem Cells, 12, 99-110.

Lyman, S. D. et al. (1994b). Cloning of the human homologue of the murine flt3 ligand: a growth factor for early hematopoietic progenitor cells. Blood, 83, 2795-2801.

Lyman, S. D. et al. (1995a). Structural analysis of human and murine flt3 ligand genomic loci. Oncogene, 11, 1165-1172.

Lyman, S. D. et al. (1995b). Plasma/serum levels of flt3 ligand are low in normal individuals and highly elevated in patients with Fanconi anemia and acquired aplastic anemia. Blood, 86, 4091-4096. 
Lyman, S. D. et al. (1995c). Identification of soluble and membranebound isoforms of the murine flt3 ligand generated by alternative splicing of mRNAs. Oncogene, 10, 149-157.

Lyman, S. D. et al. (1998). c-kit ligand and Flt3 ligand: stem/progenitor cell factors with overlapping yet distinct activities. Blood, 91, 1101-1134.

Lynch, D. H. et al. (1997). Flt3 ligand induces tumor regression and antitumor immune responses in vivo. Nature Med., 3, 625-631.

Mackarehtschian, K. et al. (1995). Targeted disruption of the flk2/flt3 gene leads to deficiencies in primitive hematopoietic progenitors. Immunity, 3, 147-161.

Manfra, D. J. et al. (2003). Conditional expression of murine flt3 ligand leads to expansion of multiple dendritic cell subsets in peripheral blood and tissues of transgenic mice. $J$. Immunol., 170, 2843-2852.

Maraskovsky, E. et al. (1996). Dramatic increase in the numbers of functionally mature dendritic cells in Flt3 ligand-treated mice: multiple dendritic cell subpopulations identified. J. Exp. Med., 184, 1953-1962.

Marchetto, S. et al. (1999). SHC and SHIP phosphorylation and interaction in response to activation of the FLT3 receptor. Leukemia, 13, 1374-1382.

Marshall, J. et al. (2004). Human serum proteins precipitated by electrophoresis or chromatography followed by tandem mass spectrometry, J. Proteome Res., 3, 364-382.

Martin, P. J. et al. (1980). Involvement of the B-lymphoid system in chronic myelogenous leukaemia. Nature, 287, 49-50.

Masson K. et al. (2009). A role of Gab2 association in Flt3 ITD mediated Stat5 phosphorylation and cell survival. Br J Haematol, 146, 193-202.

Matthews, W. et al. (1991). A receptor tyrosine kinase specific to hematopoietic stem and progenitor cell-enriched populations. Cell, 65, 1143-1152.

Meierhoff, G. et al. (1995). Expression of FLT3 receptor and FLT3-ligand in human leukemialymphoma cell lines. Leukemia, 9, 1368-1372.

Meshinchi, S. et al. (2001). Prevalence and prognostic significance of FLT3 internal tandem duplication in paediatric acute myeloid leukemia. Blood, 97, 89-94.

Meshinchi, S. et al. (2003). Activating mutations of RTK/ras signal transduction pathway in paediatric acute myeloid leukemia. Blood, 102, 1474-1479.

Mizuki, M. et al. (2000). Flt3 mutations from patients with acute myeloid leukemia induce transformation of 32D cells mediated by the Ras and STAT5 pathways. Blood, 96, 39073914. 
Mizuki, M. et al. (2002). Suppression of myeloid transcription factors and induction of STAT response genes by AML-specific Flt3 mutations. Blood, 101, 3164-3173.

Moriyama, Y. et al. (1996). Role of aspartic acid 814 in the function and expression of c-kit receptor tyrosine kinase. J. Biol. Chem., 271, 3347-3350.

Morley, G. M. et al. (1999). Cell specific transformation by c-fms activating loop mutations is attributable to constitutive receptor degradation. Oncogene, 18, 3076-3084.

Morse, M. A. et al. (2000). Preoperative mobilization of circulating dendritic cells by Flt3 ligand administration to patients with metastatic colon cancer. J. Clin. Oncol., 18, 3883-3893.

Nadler, L. M. et al. (1984). B cell origin of non-T cell acute lymphoblastic leukemia. A model for discrete stages of neoplastic and normal pre-B cell differentiation. J. Clin. Invest., 74, $332-340$.

Nakao, M. et al. (1996). Internal tandem duplication of the flt 3 gene found in acute myeloid leukemia. Leukemia, 10, 1911-1918.

Namikawa, R. et al. (1996). The FLK2/FLT3 ligand synergizes with interleukin-7 in promoting stromal-cell-independent expansion and differentiation of human fetal pro-B cells in vitro. Blood, 87, 1881-1890.

New England Biolabs Inc. (2010). Protein expression \& analysis: K. lactis protein expression kit instruction manual (\#E1000S). Version 1.1.

O'Farrell, A. M. et al. (2003). SU11248 is a novel FLT3 tyrosine kinase inhibitor with potent activity in vitro and in vivo. Blood, 101, 3597-3605.

Piacibello W. et al. (1995). Effects of human FLT3 ligand on myeloid leukemia cell growth: heterogeneity in response and synergy with other hematopoietic growth factors. Blood, 86, 4105-4114.

Palmqvist, L. et al. (2006). The Flt3 receptor tyrosine kinase collaborates with NUP98-HOX fusions in acute myeloid leukemia. Blood, 108, 1030-1036.

Parajuli, P. et al. (2001). Immunization with wild-type p53 gene sequences co-administered with Flt3 ligand induces an antigen-specific type 1 T-cell response. Cancer Res., 61, 82278234.

Pawlowska, A. B. et al. (2001). In vitro tumor-pulsed or in vivo Flt3 ligand-generated dendritic cells provide protection against acute myelogenous leukemia in nontransplanted or syngeneic bone marrow-transplanted mice. Blood, 97, 1474-1482. 
Ratajczak, M. Z. et al. (1996). FLT3/FLK-2 (STK-1) ligand does not stimulate human megakaryopoiesis in vitro. Stem Cells, 14, 146-150.

Ray, R. J. et al. (1996). Flt3 ligand supports the differentiation of early B cell progenitors in the presence of interleukin-11 and interleukin-7. Eur. J. Immunol., 26, 1504-1510.

Rogers, S. Y. et al. (1994). Evidence for internal autocrine regulation of growth in acute myeloblastic leukemia cells. Exp. Hematol., 22, 593-598.

Rombouts EJ. et al. (2004). Relation between CXCR-4 expression, Flt3 mutations, and unfavorable prognosis of adult acute myeloid leukemia. Blood, 104, 550-557.

Rosnet, O. et al (1991). Murine Flt3, a gene encoding a novel tyrosine kinase receptor of the PDGFR/CSF1R family. Oncogene, 6,1641-1650.

Rosnet, O. et al. (1993a). Human FLT3/FLK2 gene: cDNA cloning and expression in hematopoietic cells. Blood, 82, 1110-1119.

Rosnet, O. et al. (1993b). Close physical linkage of the FLT1 and FLT3 genes on chromosome 13 in man and chromosome 5 in mouse. Oncogene, 8, 173-179.

Rosnet, O. (1993c). Hematopoietic receptors of class III receptor-type tyrosine kinases. Crit. Rev. Oncog., 4, 595-613.

Rosnet, O. et al. (1996). Human FLT3/FLK2 receptor tyrosine kinase is expressed at the surfaceof normal and malignant hematopoietic cells. Leukemia, 10, 238-248.

Rottapel, R. et al. (1994). Substrate specificities and identification of a putative binding site for $\mathrm{PI} 3 \mathrm{~K}$ in the carboxy tail of the murine Flt3 receptor tyrosine kinase. Oncogene, 9, 17551765.

Rubartelli, A. et al. (1983). Differentiation of chronic lymphocytic leukemia cells: correlation between the synthesis and secretion of immunoglobulins and the ultrastructure of the malignant cells. Blood, 62, 495-504.

Rusten, L. S. et al. (1996). The FLT3 ligand is a direct and potent stimulator of the growth of primitive and committed human CD34+ bone marrow progenitor cells in vitro. Blood, 87 , $1317-1325$.

Sabbath, K. D. et al. (1985). Heterogeneity of clonogenic cells in acute myeloblastic leukemia. $J$. Clin. Invest., 75, 746-753.

Saito T. et al. (2008). Combined mobilization and stimulation of tumor-infiltrating dendritic cells and natural killer cells with Flt3 ligand and IL-18 in vivo induces systemic antitumor immunity. Cancer Sci, 99, 2028-2036. 
Saunders, D. et al. (1996). Dendritic cell development in culture from thymic precursor cells in the absence of granulocyte/macrophage colony-stimulating factor. J. Exp. Med., 184, 2185-2196.

Sambrook, J. \& Russell, D.W. (2001). Identification of associated proteins by coimmunoprecipitation. Molecular Cloning: A Laboratory Manual. New York, NY.

Savvides S.N. et al. (2000). Flt3 ligand structure and unexpected commonalities of helical bundles and cystine knots. Nat. Struct. Biol., 7, 486-491.

Seedhouse CH. et al. (2006). DNA repair contributes to the drug-resistant phenotype of primary acute myeloid leukaemia cells with FLT3 internal tandem duplications and is reversed by the FLT3 inhibitor PKC412. Leukemia, 20, 2130-2136.

Schnittger, S. et al. (2002). Analysis of FLT3 length mutations in 1003 patients with acute myeloid leukemia: correlation to cytogenetics, FAB subtype, and prognosis in the AMLCG study and usefulness as a marker for the detection of minimal residual disease. Blood, 100, 59-66.

Shah, A. J. et al. (1996). Flt3 ligand induces proliferation of quiescent human bone marrow CD34+CD38- cells and maintains progenitor cells in vitro. Blood, 87, 3563-3570.

Small, D. et al. (1994). STK-1, the human homolog of Flk-2/Flt-3, is selectively expressed in CD34+ human bone marrow cells and is involved in the proliferation of early progenitor/stem cells. Proc. Natl Acad. Sci. USA, 91, 459-463.

Spiekermann, K. et al. (2002). A new and recurrent activating length mutation in exon 20 of the FLT3 gene in acute myeloid leukemia. Blood, 100, 3423-3425.

Srinivasa, S. P. \& Doshi, P. D. (2002). Extracellular signal-regulated kinase and p38 mitogenactivated protein kinase pathways cooperate in mediating cytokine-induced proliferation of a leukemic cell line. Leukemia, 16, 244-253.

Stephen, FA.et al. (1997). Gapped BLAST and PSI-BLAST: a new generation of protein database search programs. Nucleic Acids Res, 25, 3389-3402.

Stirewalt, D. L. et al. (2001). FLT3, RAS and TP53 mutations in elderly patients with acute myeloid leukemia. Blood, 97, 3589-3595.

Streeter, PR. et al. (2003). Activation of the G-CSF and Flt-3 receptors protects hematopoietic stem cells from lethal irradiation. Exp. Hematol, 31, 1119-1125.

Teleshova N. et al. (2004). Short-term Flt3L treatment effectively mobilizes functional macaque dendritic cells. J. of Leuk. Bio., 75, 1102-1108. 
Thiede, C. et al. (2002). Analysis of FLT3-activating mutations in 979 patients with acute myelogenous leukemia: association with FAB subtypes and identification of subgroups with poor prognosis. Blood, 99, 4326-4335.

Turner, A. M. et al. (1996). FLT3 receptor expression on the surface of normal and malignant human hematopoietic cells. Blood, 88, 3383-3390.

Veiby, O. P. et al. (1996). Combined signaling through interleukin-7 receptors and flt3 but not ckit potently and selectively promotes B-cell commitment and differentiation from uncommitted murine bone marrow progenitor cells. Blood, 88, 1256-1265.

Vosshenrich, CA. et al. (2003). Thymic stromal-derived lymphopoietin distinguishes fetal from adult B cell development. Nat. Immunol, 4, 773-779.

Vu HA. et al. (2009). The juxtamembrane domain in ETV6/FLT3 is critical for PIM-1 upregulation and cell proliferation. Biochem Biophys Res Commun, 383, 308-313.

Wang, GG. et al. (2005). Meis1 programs transcription of FLT3 and cancer stem cell character, using a mechanism that requires interaction with $\mathrm{Pbx}$ and a novel function of the Meis1 C-terminus. Blood, 106, 254-264.

Weiss, A. \& Schlessinger, J. (1998). Switching signals on or off by receptor dimerization. Cell, 94, 277-280.

Weisberg, E. et al. (2002). Inhibition of mutant FLT3 receptors in leukemia cells by the small molecule tyrosine kinase inhibitor PKC412. Cancer Cell, 1, 433-443.

Wilhelm, SM. et al. (2004). BAY 43-9006 exhibits broad spectrum oral antitumor activity and targets the RAF/MEK /ERK pathway and receptor tyrosine kinases involved in tumor progression and angiogenesis. Cancer Res, 64, 7099-7109.

Wolf, I. \& Rohrschneider, L.R. (1999). Fiz1, a novel zinc finger protein interacting with the receptor tyrosine kinase Flt3. J Biol Chem, 30, 21478-21484.

Xu, F. et al. (1999). Tandem duplication of the FLT3 gene is found in acute lymphoblastic leukaemia as well as acute myeloid leukaemia but not in myelodysplastic syndrome or juvenile chronic myelogenous leukaemia in children. Br. J. Haematol., 105, 155-162.

$\mathrm{Xu}, \mathrm{ZX}$ et al. (2000). Expression of Human Flt3 Ligand in Pichia pastoris and its Biological Characteristics. Sheng Wu Hua Xue Yu Sheng Wu Wu Li Xue Bao (Shanghai), 32, $217-$ 222.

Yamamoto, Y. et al. (2001). Activating mutation of D835 within the activation loop of FLT3 in human hematologic malignancies. Blood, 97, 2434-2439. 
Yee, N. S. et al (1993). Mechanism of kit ligand, phorbol ester, and calcium-induced downregulation of c-kit receptors in mast cells. J. Biol. Chem., 268, 14189-14201.

Yee, K. W. et al. (2002). SU5416 and SU5614 inhibit kinase activity of wild-type and mutant FLT3 receptor tyrosine kinase. Blood, 100, 2941-2949.

Yokota, S. et al. (1997). Internal tandem duplication of the FLT3 gene is preferentially seen in acute myeloid leukemia and myelodysplastic syndrome among various haematological malignancies. A study on a large series of patients and cell lines. Leukemia, 11, 16051609.

Yoshimoto G. et al. (2009). FLT3-ITD up-regulates MCL-1 to promote survival of stem cells in acute myeloid leukemia via FLT3-ITD-specific STAT5 activation. Blood, 114, 50345043.

Zhao X. et al. (2010). Expression, purification and characterization of the extracellular domain of human FLT3 ligand in Escherichia coli. Mol Biol Rep, 37, 2301-2307.

Zhang Y. et al. (2005). Functional expression, purification, and characterization of human FLT3 ligand in the Pichia pastoris system. Protein Expression and Purification, 45, 246-254.

Zhang, S. et al. (1999a). Flt3 signalling involves tyrosyl-phosphorylation of SHP-2 and SHIP and their association with Grb2 and Shc in Baf3/Flt3 cells. J. Leukocyte Biol., 65, 372380 .

Zhang, S. et al. (1999b). p85 subunit of PI3 kinase does not bind to human Flt3 receptor, but associates with SHP2, SHIP, and a tyrosine-phosphorylated 100-kDa protein in Flt3 ligand-stimulated hematopoietic cells. Biochem. Biophys. Res. Commun., 254, 440-445.

Zhang, S. et al. (2000a). Essential role of signal transducer and activator of transcription (Stat)5a but not Stat5b for Flt3-dependent signalling. J. Exp. Med., 192, 719-728.

Zhang, S. et al (2000b). Flt3 ligand induces tyrosine phosphorylation of gab1 and gab2 and their association with shp-2, grb2, and PI3 kinase. Biochem. Biophys. Res. Commun., 277, 195-199.

Zhang Y. et al. (2009). Synergistic protecting effect of cord blood CD34+ cells over-expressing both interleukin-3 and Flt3 ligand on lethally irradiated mice. Int. J. Hematol., 90, 64-73.

Zheng, R. et al. (2002). Targeted inhibition of FLT3 overcomes the block to myeloid differentiation in 32Dcl3 cells caused by expression of FLT3/ITD mutations. Blood, 100, 4154-4161. 